SH 365

.$\vee 7 \quad M 7$

Copy 1 


$$
\text { ช }
$$






DEPARTMENT OF COMMERCE AND LABOR BUREAU OF FISHERIES

CEORGE N. BOWERS, Commílione:

\section{CONDITION AND EXTENT OF THE OYSTER BEDS OF JAIIES RIVER, VIRGINIA}

Burreat of Fisberies Document No, 729

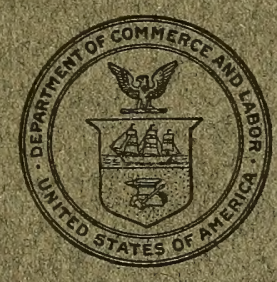

WASHINGTON

GOVERIMIENT PRINTING OFFICE 1910 

DEPARTMENT OF COMMERCE AND LABOR BUREAU OF FISHERIES GEORGE M. BOWERS, Commissioner

\section{CONDITION AND EXTENT OF THE OYSTER BEDS OF JAIIES RIVER, VIRGINIA}

\section{Bureau of Fisheries Document No. 729}

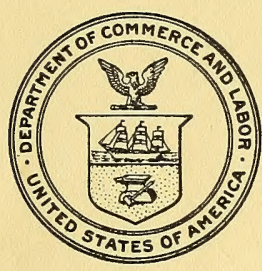

WASHINGTON

GOVERNMENT PRINTING OFFICE 1910 


$$
5 H^{30^{5}} \sqrt{11}
$$

JAN 221910

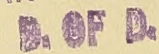

$$
\because \vdots
$$




\title{
CONDITION AND EXTENT OF THE OYSTER BEDS OF JAMES RIVER, VIRGINIA
}

\author{
BY H. F. MooRE
}

Assistant, U. S. Bureau of Fisheries

Bureau of Fisheries Document No. 729 



\section{P R E F A C E.}

On February 3, 1909, the Bureau of Fisheries received from Hon. Claude A. Swanson, governor of Virginia, a communication inclosing the following resolution of the Commissioners of Fisheries of the State:

Resolved, That the governor be requested to enlist the services of the United States Bureau of Fisheries in determining and defining the fertile and the barren areas in James River, marking and platting same, provided it can be done without expenditure by the State.

At the urgent solicitation of Governor Swanson, and upon the conviction that the work would prove of value as a guide for contemplated legislation by the State in respect to the future administration of the public oyster grounds, the request for the survey was acceded to, the steamer Fish Hawk and civilian assistants were detailed for the work, and Dr. H. F. Moore, assistant in the Bureau of Fisheries, was directed to assume charge.

The erection of signals was begun early in July and completed by August 7. The actual examination of the oyster beds commenced on August 9 and extended, with only such interruptions as were due to the weather, to September 14, the survey thus covering the period just prior to the opening of the oyster season, when the beds were in their optimum condition. Under the terms of the resolution quoted above, the Bureau has not felt justified in offering advice as to the future treatment of the beds, and the following report is therefore confined to statements of fact and a short discussion of their several obvious avenues of application.

George M. Bowers, Commissioner.

United States Bureau of Fisheries,

Washington, D. C., December 1, 1909. 



\section{CONTENTS.}

Page.

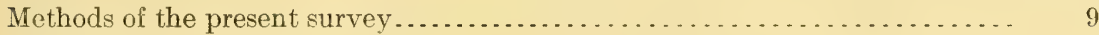

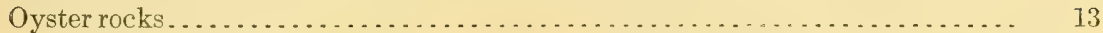

Market oyster area-

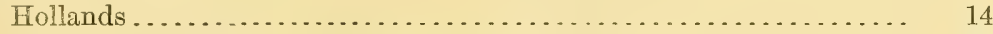

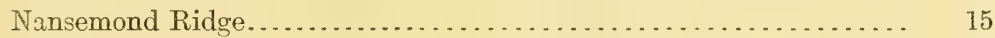

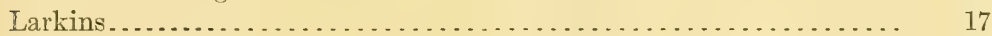

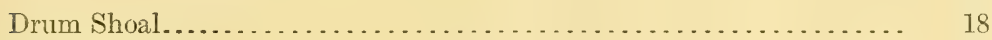

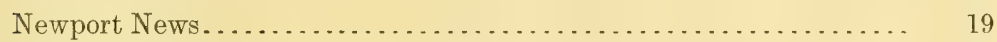

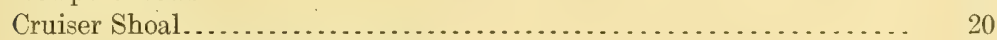

Flat Rock and adjacent small beds...................... 21

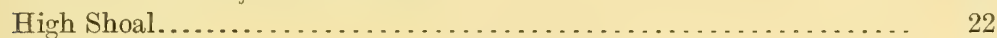

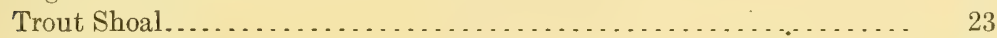

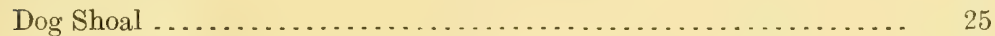

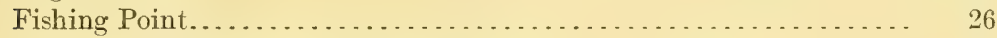

Between Fishing Point and Ballards Marsh................... . . . 27

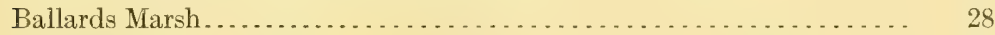

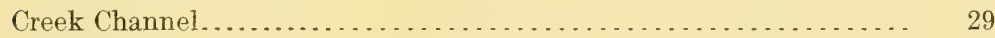

Aaron Shoal. ... . . . .

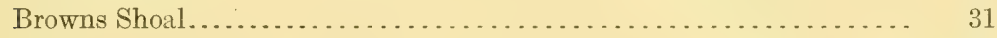

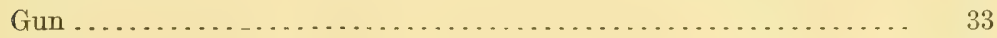

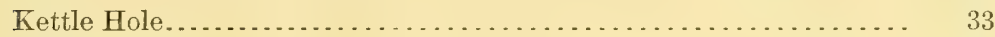

Thomas Point........................................ 35

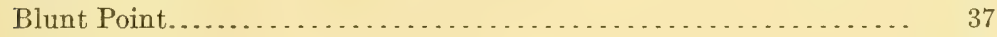

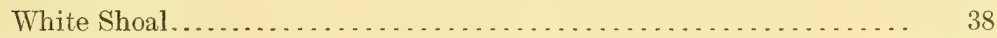

Seed oyster area-

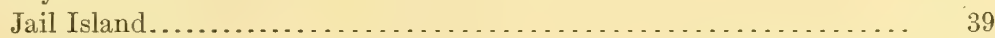

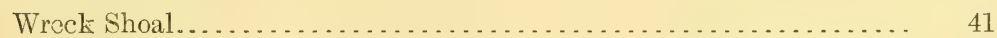

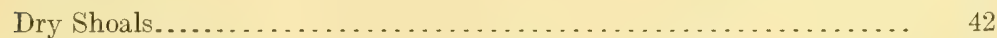

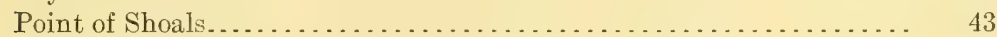

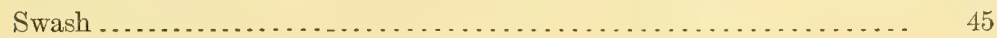

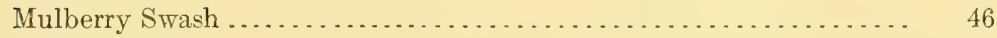

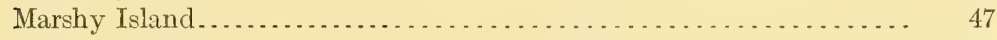

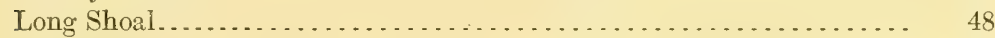

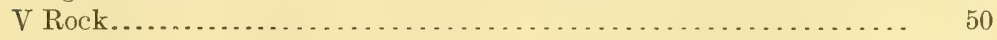

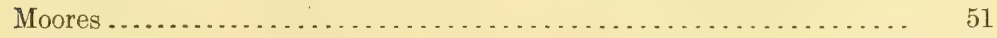

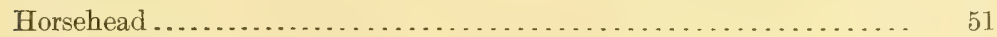

Deepwater Shoals. . . . . . . . . . . . . . . . . . . . . . . . . 53

Rock Wharf Shoals... . . . . . . . . . . . . . . . . . . . . . . . . . 54

Beds between Rock Wharf Shoals and Spindle Rock.............. . 54

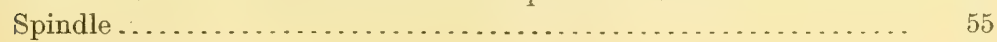

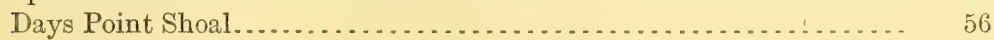


Page.

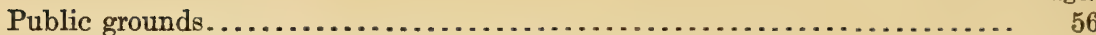

No. 2 Nansemond County and No. 6 Isle of Wight County.............. . 60

No. I Warwick County below Deep Creek......................... 64

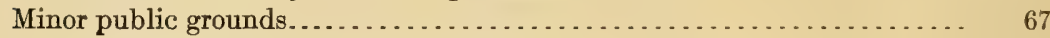

No. I Warwick County above Deep Creek....................... 67

No. I Isle of Wight County ............................... $\quad 70$

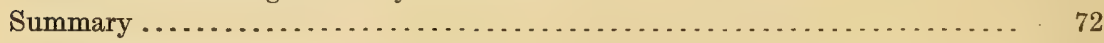

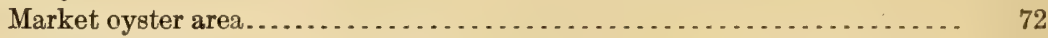

Seed oyster area.......................................... 77

Conclusion................................................... 80

Description of charts.............................................. 83 


\section{CONDITION AND EXTENT OF THE OYSTER BEDS OF JAMES RIVER, VIRGINIA.}

By H. F. Moore, Assistant, U. S. Bureau of Fisheries.

\section{PREVIOUS SURVEYS.}

Prior to the investigations made by the Bureau of Fisheries in July, August, and September, 1909, two surveys of the James River oyster beds had been made, neither of which professed to delineate the rocks accurately or to furnish detailed information concerning their productiveness and condition. The first of these surveys was a reconnoissance made in 1878 by Lieut. (then Master) Francis Winslow, U. S. Navy, in command of the Coast and Geodetic Survey schooner Palinurus. The second was the survey of the public grounds by Mr. J. B. Baylor, assistant, Coast and Geodetic Survey, under the authority of the State, in 1892 and preceding years.

As Winslow himself states, his "examination of these beds was a very hurried one, and the delineation must be regarded as merely approximate, being the result of a hasty reconnoissance." The chart published with the report delineates merely the general outlines of the oyster-bearing areas, without attempting to show the smaller individual rocks or the density of growth, and the text is of very general character. Comparing the chart with the results of the recent survey, however, it is evident that Lieutenant Winslow's brief investigation must have shown with considerable accuracy the general distribution of oysters in the James and Nansemond rivers at that time. The differences between the general results of the two surveys are such as could be readily produced by the lapse of time and the vicissitudes through which the beds have passed under the operation of natural and human agencies. Some areas have bccome depleted through the intensive fishing they have sustained, or from the effects of freshets and other physical factors, while on the other hand some appear to have had their boundaries extended or have become merged with adjacent beds through the operations of the tongers. 
The Baylor survey was of an entirely different character from that conducted by Winslow. It was in no sense an examination of the oyster beds themselves, but primarily and avowedly a delimitation of boundaries which included the recognized or reputed oyster-bearing bottom, as pointed out by local commissioners or representatives of each oyster-producing county. It is the writer's understanding that the county commissioners were, under the state law ordering the survey, the final arbiters with whom rested the decision whether or not a given area should be included within the boundaries of the public grounds. So far as can be learned no examinations whatever were made on the beds, the commissioners using their judgment and local knowledge in selecting the corners and the engineers with their theodolites cutting in the points indicated from stations on the shore.

Whether or not beds were omitted from the confines of the public grounds so located can not now be satisfactorily determined, owing to the development of the planting industry, outside of the Baylor lines, on all or most of the available bottom. It is evident, however, that in the region under discussion no very extensive rocks were disregarded, and a comparison of the results of the recent survey with that of 1892 shows that the Baylor lines, considered as a broad scheme of delimitation, conform closely with the general distribution of the rocks. At several places, notably on Gun and Kettle Hole rocks, parts of the natural beds undoubtedly fell outside of the lines, but the writer hazards the suggestion that this may not have been through inadvertence but because those parts of the rocks may have been already taken up as private holdings.

It has been claimed, and Mr. Baylor himself has so stated in official communications to the State, that a very considerable area of barren bottom, amounting to many thousand acres, was included within the public grounds. That this should be so, under the system adopted by the local commissioners and under the desire to assure the inclusion of all naturally productive bottom, was inevitable. Moreover, the boundaries of the beds are irregular curves, while the including surveyed boundaries must be straight lines, for purposes of administration and policing as long and unbroken as possible. To have excluded the greater part of this barren bottom would have necessitated a careful location of the natural rocks and the breaking up of the public grounds into a considerable number of small or moderate areas instead of segregating them into a few large ones.

To what extent the claim that great areas of barren bottom are included in the public grounds is justified will appear from the accompanying charts and in the following descriptions and discussions. 


\section{METHODS OF THE PRESENT SURVEY.}

To furnish authoritative and definite information as to the actual extent and condition of the natural rocks and the character of the bottoms embraced within the boundaries of the public beds, it was necessary to depart widely from the methods of the previous surveys.

It was decided to confine the investigation wholly to the public beds, passing their boundaries only far enough to give assurance that the entire area had been covered. Nothing was to be gained by an examination of the excluded areas, as it is now almost impossible to determine whether natural rocks were omitted from the grounds laid out in 1892, and it is too late to correct such omissions if they could be determined. For legal purposes, all that is not avowedly public ground is barren bottom, and if held under leasehold from the State can not be alienated from the possession of the lessees as long as the law has been complied with.

The methods followed have been essentially those pursued in former surveys conducted by the Bureau of Fisheries, with the changes and improvements dictated by recent experience and the local conditions.

The Coast and Geodetic Survey furnished projections on which were platted the triangulation points used in former surveys by that bureau. Several of these points, including the light-houses, were "recovered," and from them the signals, usually tripods, erected where necessary, were cut in and platted by means of the sextant and 3 -arm protractor. This method, while lacking the great precision attained by means of the best theodolites and the nice computations employed by the Coast Survey in its work, insures an accuracy more than sufficient for the purposes of an oyster survey.

The oyster beds were discovered by soundings with a lead line, but principally by means of a length of chain dragged over the bottom at the end of a copper wire running from the sounding boat. The wire was wound on a reel and its unwound length was adjusted to the depth of water and the speed of the launch, so that the chain was always on the bottom. Whenever the chain touched a shell or an oyster the shock or vibration was transmitted up the wire to the hand of a man whose sole duty it was to give heed to such signals and report them to the recorder.

The launches from which the soundings were made were run at a speed of between 3 and 4 miles per hour, usually on ranges ashore to insure the rectitude of the lines. At intervals of three minutes-in some cases two minutes-the position of the boat was determined by two simultaneous sextant observations of the angles between a set of three signals, the middle one of which was common to the two angles, the position being immediately platted on the boat sheet. At regular intervals of twenty seconds, as measured by 
a clock under the observation of the recorder, the leadsman made a sounding and reported to the recorder the depth of water and the character of the bottom, immediately after which the man at the wire reported the character of the chain indications since the last sounding - that is, whether they showed barren bottom or dense, scattering, or very scattering growths of oysters.

With the boat running at 3 miles per hour the soundings were between 80 and 90 feet apart and, as the speed of the boat was uniform, the location of each was determinable within a yard or two by dividing the platted distance between the positions determined by the sextant by the number of soundings. The chain, of course, gave a continuous indication of the character of the bottom, but the record was made at the regular twenty-second intervals observed in sounding.

The chain, while indicating the absence or the relative abundance of objects on the bottom, gives no information as to whether they are shells or oysters, nor, if the latter, their size and condition. To obtain this data it was necessary to supplement the observations already described by others more definite in respect to the desired particulars. Whenever in the opinion of the officer in charge of the sounding boat such information was required, a numbered buoy was dropped, the time and number being entered in the sounding book. Another launch, following the sounding boat, anchored alongside the buoy, and a quantity of the oysters and shells were tonged up, separated by sizes, and counted.

In former surveys made by the writer, in order to arrive at an estimate of the density of the oyster growth a definite area, usually 5 yards, was staked off by means of steel-shod pikes and everything was removed from the bottom and counted. This method is accurate, but slow and difficult in deep water, and, as it was desirable to make a large number of observations, the system developed in the Maryland survey was adopted. This consists essentially in making a known number of "grabs" with the oyster tongs, exercising care to clean the bottom of oysters as thoroughly as possible at each grab. In a given depth of water and using the same boat and tongs an oysterman will cover practically the same area of the bottom at each grab, but, other factors remaining the same, the area of the grab will decrease with an increase in the depth.

Careful measurements were made and tabulated showing the area per grab covered by the tonger employed on the work at each foot of depth of water and for each pair of tongs and boat used. With this data, and knowing the number of "grabs," the number of oysters of each size per square yard of bottom was readily obtainable by simple calculation. The following example will illustrate the data obtained and the form of the record: 
Department of Commerce and Labor.

BUREAU OF FISHERIES.

Field record of examinations of oyster beds.

General locality: James River.

Local name of oyster ground: Between Rock wharf and Spindle rock.

Date: August 28, 1909.

Time: $9.25 \mathrm{a} . \mathrm{m}$.

Angle: F. 140.

Buoy No.: 23.

Depth: " 7 feet.

Bottom: Hard.

Condition of water: Medium clear.

Density:

Temperature:

Current:

Stage of tide:

Tongman: Lawrence, in flatboat.

No. grabs made: 8 .

Total area covered: $3 \frac{1}{2}$ square yards ..

No. oysters taken: $\left\{\begin{array}{l}-1 \text { in.: } 27 . \\ X \text { in. }-4 \text { in.: } 10 .\end{array}\right.$

Tongs: 14 feet.

1 in. $-\mathrm{X}$ in.: 69 .

4 in.: 3.

Quantity shells: $\frac{1}{3}$ bushel.

Result: $\left\{\begin{array}{l}\text { Spat per square yard: } 7.7 \\ \text { Culls per square yard: } 19.7 . \\ \text { Counts per square yard: } 3.7\end{array}\right.$

$\mathrm{X}$ in.$=$ cull limit prescribed by law.

This furnishes an exact statement of the condition of the bed at a spot which can be platted on the chart with error in position of not more than a few yards. From the data obtained a close estimate may be formed of the bushels of oysters and shells per acre in the vicinity of the examination and, by multiplying the observations, for the bed as a whole. In the course of the survey 590 observations were made at various places, principally on the natural rocks, but some on the barren bottoms also.

In former surveys by the Bureau the relative density of the oyster growth has been considered solely from the standpoint of the total quantity of oysters. That method is satisfactory where the depth is fairly uniform throughout the region examined, but was not considered accurate enough for the purposes of the present report.

With a given quantity of oysters per square yard or acre, a bed lying in shoal water is more valuable commercially than one in deep water, owing to the fact that the labor of the tonger is more efficient in the former. As has been pointed out, the area covered by a "grab" decreases with an increase in depth, and, moreover, the deeper the water the greater is the labor involved in making the "grab" and the smaller is the number of grabs which can be made per hour or per day. With 14-foot tongs used from a canoe, such as is employed 
on the James River, an oysterman can cover twice as much bottom per grab in 4 feet as he can in 8 feet, and about two and one-half times as much as he can using 20 -foot tongs in 16 feet. Using the tongs stated, the average tonger observed in Maryland, and the data will hold in Virginia, will make about 2.7 grabs per minute in 4 feet, 2.6 in 8 feet, and 1.8 in 16 feet of water. In other words, if he can cover 1 square yard of the bottom in a given time in 16 feet, he can cover 1.7 yards in 8 feet, and 3.3 yards in 4 feet of water.

It is obvious that if a tonger in a given time is to obtain the same quantity of oysters in each of these depths, the oyster growth must lie on the bottom with a density inversely to the areas stated above. The value of a bed, the price per bushel of the oysters being the same, depends on the quantity which a man can take in a given time, and it therefore happens that a bed in deep water may be valueless commercially, while another rock, with the same density of growth but covered by shoaler water, may be tonged with profit.

Based on these principles, and taking into consideration the number of oysters per bushel on the different beds as determined by actual counts, tables were prepared showing the number of oysters per square yard for each foot of depth necessary to yield to the tonger 1 bushel of oysters per day of tonging. From these data the beds were divided into areas, according to the number of bushels of oysters which they were capable of yielding per day to the tonger, based on nine hours of actual tonging and disregarding the time occupied in culling. The bottom was divided into 5 categories: Barren, on which there were neither shells nor oysters; depleted, on which the tonger could take less than 3 bushels of market oysters or 4 bushels of seed, according to location; very scattering growth, on which between 3 and 5 bushels of oysters or 4 and 8 bushels of seed could be taken; scattering growth, on which the limits were 5 and 8 bushels of market oysters or 8 and 12 bushels of seed; and areas of dense growth, on which upward of 8 bushels of market oysters or 12 bushels of seed could be taken per day.

During the survey 10,440 soundings were taken, and the position of the boat was instrumentally determined at 1,369 places. The chain was dragged for 226 miles, giving continuous indications of the character of the bottom, which were plotted on the chart at 10,440 places. The density of oyster growth was determined by the 590 biological observations already referred to, and the extent and boundaries of the areas as charted were fixed by a combination of these observations and the 10,440 records of the continuous chain readings. During the work the writer was in charge of the sounding boat and in constant touch with all operations. The biological observations were all under the immediate charge of Mr. T. E. B. Pope, whose 
experience in such work is such as insured their accuracy both as to the area covered by the tonger and the quantity of oysters taken. The oysters brought in by the biological party were all examined by the author, who has also personally made all of the many calculations required and directly supervised the laying off of the areas on the charts. The basis for the determination of the character of the beds was decided on in advance, but the work of the survey was so planned that it was impossible for any member of the party to form an opinion as to the conditions found until after the field work was completed, and any involuntary prejudice was thus eliminated as far as possible. The author himself could form but a vague idea of the general results until the charts were completed and the report almost written.

In the following pages the subject is gradually developed from a detailed description of the several parts of the individual natural rocks to a broad consideration of the market oyster and seed areas as a whole, and in every case there is given the principal data on which the several statements are based.

\section{OYSTER ROCKS.}

The term "oyster rock," as used in Virginia and employed in this report, is synonymous with natural oyster bed and is to be distinguished from the term "public ground," which is used to designate the areas legally embraced within surveyed lines and set apart for the use of the public. The public grounds were intended to embrace all of the oyster rocks, and usually each includes a number of the latter within its confines.

An oyster rock is usually a more or less definite area of bottom, limited by the extent of actual oyster growth. Originally, the boundaries were rather definitely marked and the rocks were separated from one another by barren areas, but the operations of oystering have in many cases strewn oysters and shells over the surrounding bottom, so that in cases the original limits have become obscured and adjacent rocks merged.

On the accompanying chart much of the bottom indicated as depleted really represents the areas which have been thus covered with scattered oysters and shells, and the term employed indicates that oysters and shells are very scarce rather than that they have been removed, though the latter is the fact in many cases. The so-called "depleted" areas are those on which oysters grow in quantities much below those which would make it commercially profitable to tong for them.

The boundaries of the rocks, as shown by the red inclosing lines on the charts and as considered in the text, were defined by the 
results of the chain indications, the methods of obtaining which have been before explained. All areas in which shells or oysters were encountered are regarded as rocks, but their character, so far as productiveness is concerned, was determined by tonging and counting the yield in the manner heretofore described. The depleted areas, except where it is shown that they contain a reasonably heary growth of young, may be regarded as worthless from the viewpoint of the tonger; the areas of very scattering growth are of doubtful value except where a heavy growth of young oysters indicates potential improvement, while the areas of scattering and dense growth can be regarded as really productive natural rocks. The barren bottom, which is shown on the chart as an unshaded area outside of the red lines, is that on which neither oysters nor shells were found. A few small unshaded areas inclosed by red lines indicate beds the exact nature of which was not accurately determined.

An attempt is made in this report to designate the rocks by the names employed by the oystermen, so far as these could be ascertained. In several cases, as for instance "Fishing Point Rocks" and "Marshy Island Rock," names have been coined to serve the purposes of reference and designation. The exact extent of Point of Shoals Rock was not definitely ascertained, and as shown on the chart it may not accord with the usage of the oystermen. There was also some doubt about the location of Kettle Hole and Thomas Point Rocks, but, as the names used in the text are clearly shown on the charts, there can be no confusion in the references. In a number of cases where the several beds were more or less continuous with one another arbitrary boundaries have been adopted, but, as these usually pass through depleted areas and as in a later discussion the rocks are considered as a whole in their grouping in the public beds, the necessity for this treatment causes no loss in the final accuracy or exactitude.

In the following pages the rocks are considered in detail.

\section{MARKET OYSTER AREA.}

HOLLANDS ROCK.

This was intended to be included by the Baylor survey in Public Ground No.3, Nansemond County, though it is stated that a mistake was made by which it was omitted. The area, 22 acres, which is described under this name included the only bottom within the public ground which gave any indication of being an oyster bed, though the examination showed it to be depleted. It is completely surrounded by planted beds.

The results of the examination were as follows: 
Details of Examination of Hollands Rock.

\begin{tabular}{|c|c|c|c|c|c|c|c|c|c|}
\hline \multirow{2}{*}{$\begin{array}{c}\text { Station } \\
\text { num- } \\
\text { ber. }\end{array}$} & \multirow{2}{*}{$\begin{array}{l}\text { Date of ex- } \\
\text { amination. }\end{array}$} & \multirow{2}{*}{$\begin{array}{c}\text { Mean } \\
\text { depth } \\
\text { of wa- } \\
\text { ter. }\end{array}$} & \multirow{2}{*}{$\begin{array}{l}\text { Character of growth } \\
\text { of market oysters. }\end{array}$} & \multicolumn{3}{|c|}{$\begin{array}{l}\text { Oysters caught per } \\
\text { square yard. }\end{array}$} & \multicolumn{3}{|c|}{$\begin{array}{l}\text { Estimated quantity of } \\
\text { oysters per acre. }\end{array}$} \\
\hline & & & & Spat. & Culls. & Counts. & Seed. & Market. & Total. \\
\hline $\begin{array}{r}4 \\
30\end{array}$ & $\begin{array}{l}\text { Aug. 9,1909 } \\
\text { Aug. 11, } 1909\end{array}$ & $\begin{array}{r}\text { Feet. } \\
11.0 \\
9.5\end{array}$ & $\begin{array}{l}\text { Depleted. } \\
. . . \text { do } . . . .\end{array}$ & $\begin{array}{l}0 \\
0\end{array}$ & $\begin{array}{r}0.4 \\
0\end{array}$ & $\begin{array}{r}1.8 \\
0\end{array}$ & $\begin{array}{r}\text { Bush. } \\
3 \\
0\end{array}$ & $\begin{array}{r}\text { Bush. } \\
29 \\
0\end{array}$ & $\begin{array}{r}\text { Bush. } \\
-\quad 32 \\
0\end{array}$ \\
\hline
\end{tabular}

\section{NANSEMOND RIDGE ROCK.}

This is the principal and only productive bed in Nansemond River. It lies mainly on and about a shoal extending through the middle of the river from Cedar Point almost to the middle of James River, opposite Newport News. At its northern end it is connected, by an unproductive, practically barren area, with three smaller rocks hereafter described. Its area, density of oyster growth, and contents are as follows:

Oyster Growth on Nansemond Ridge Rock.

\begin{tabular}{|c|c|c|c|c|}
\hline \multirow{2}{*}{ Character of growth of market oysters. } & \multirow{2}{*}{ Area. } & \multicolumn{2}{|c|}{ Oysters per acre. } & \multirow{2}{*}{$\begin{array}{l}\text { Estimated } \\
\text { content } \\
\text { of market } \\
\text { oysters. }\end{array}$} \\
\hline & & Seed. & Market. & \\
\hline $\begin{array}{l}\text { Dense } \\
\text { Seattering. } \\
\text { Very scattering } \\
\text { Depleted. }\end{array}$ & $\begin{array}{r}\text { Acres. } \\
85 \\
446 \\
294 \\
782\end{array}$ & $\begin{array}{r}\text { Bushels. } \\
148 \\
133 \\
34 \\
35\end{array}$ & $\begin{array}{r}\text { Bushels. } \\
93 \\
60 \\
37 \\
11\end{array}$ & $\begin{array}{r}\text { Bushels. } \\
7,905 \\
26,760 \\
10,878 \\
8,602\end{array}$ \\
\hline Total. & 1,607 & & & 54,145 \\
\hline
\end{tabular}

The market oysters on this bed are large, averaging at the time of the survey a few over 300 per bushel. They are said to attain a good condition, particularly late in the season, and are used mainly by shucking houses. The small oysters ran about 750 per bushel.

The broadest, largest, and most productive part of the bed stretches northward from opposite Pig Point on the west side of the channel. It is estimated that this portion has an area of about 1,156 acres, of which 69 acres bear a dense growth of market oysters, 386 acres a scattering growth, 201 acres a very scattering growth, and 500 acres are depleted. The latter does not include the barren bottom embraced between the edges of the bed and the lines of the Baylor survey. It is further estimated that on the dense bottom a man tonging exclusively could take in a day about 10 bushels of market oysters, on the scattering area about 6 bushels, on the very scattering part about $3 \frac{1}{4}$ bushels, while on the depleted area he could not take an average of over 1 bushel. These estimates are for the beginning of the season, $20201-10-2$ 
and any considerable tonging of the beds would soon materially reduce the average catch per day.

In the dense and scattering parts of this portion of the bed, especially near the crest of the ridge, there is a growth of small oysters so dense that an average of upward of 12 bushels could be tonged per day, and these areas can undoubtedly be regarded as both presently and prospectively productive. There is also a dense growth of young oysters on the inner parts of the depleted area opposite Nansemond River Light. On the areas of very scattering growth the small oysters are in even smaller quantity than the market oysters, but in places there are clean shells in sufficient quantity to indicate that under proper conditions a good set might occur and the bottom become fairly productive.

Above a line drawn between Pig Point and Barrel Point the bed may be divided into two parts, one a tail-like continuation of the main bed running along the eastern edge of the channel and the other a detached portion lying on a shoal west of the channel, north of Larkins Rock. The former has 126 acres of depleted bottom and two small patches, one of scattering growth covering about 22 acres and the other of about 41 acres on which the oysters are very scattering. The detached area covers about 260 acres, of which 15 are dense, 39 scattering, 51 very scattering, and 155 depleted. On the areas of dense and scattering growths of market oysters there is a heavy growth of culls, but the scattering and depleted areas are generally impoverished of young.

On the two areas just described as lying above a line between Pig and Barrel points it is estimated that there are 15 acres of dense growth on which a man could tong an average of about 8 barrels of market oysters per day, 61 acres on which he could average about 5 bushels, 92 acres of very scattering growth where he could take about 4 bushels per day, and 281 acres of depleted bottom which will not yield 1 bushel per day. On the depleted area there are few young oysters and practically no shells. The barren bottom lying within this part of the Baylor survey, on which oysters do not now grow and apparently never have grown in marketable quantities, nearly equals all of the foregoing combined, covering about 430 acres. The barren and depleted bottom together aggregate about 711 acres, while all of the bottom which is capable of yielding even as little as 3 bushels per day, exclusive of the time consumed in culling, covers about 168 acres. In other words, at least 80 per cent of the area is at present commercially worthless.

The observations, in addition to the sounding and chain investigations, on which the foregoing is based, are as follows: 
Details of Examination of Nansemond Ridge Rocks.

\begin{tabular}{|c|c|c|c|c|c|c|c|c|c|}
\hline \multirow{2}{*}{$\begin{array}{c}\text { Station } \\
\text { num- } \\
\text { ber. }\end{array}$} & \multirow{2}{*}{$\begin{array}{l}\text { Date of ex- } \\
\text { amination. }\end{array}$} & \multirow{2}{*}{$\begin{array}{c}\text { Mean } \\
\text { depth } \\
\text { of wa- } \\
\text { ter. }\end{array}$} & \multirow{2}{*}{$\begin{array}{l}\text { Character of growth } \\
\text { of market oysters. }\end{array}$} & \multicolumn{3}{|c|}{$\begin{array}{l}\text { Oysters caught per } \\
\text { square yard. }\end{array}$} & \multicolumn{3}{|c|}{$\begin{array}{l}\text { Estimated quantity oys- } \\
\text { ters per acre. }\end{array}$} \\
\hline & & & & Spat. & Culls. & Counts. & Seed. & Market. & Total. \\
\hline & & Feet. & & & & & Bush. & Bush. & Bush. \\
\hline 1 & Aug. 9, 1909 & 13. $\theta$ & Dense............ & 6.0 & 5. 1 & 8.2 & 72 & 132 & 204 \\
\hline 549 & Sept. 13, 1909 & 6.5 & ... do do . . . . . & 4. 7 & 27.7 & 4.7 & 209 & 76 & 285 \\
\hline 582 & Sept. 14,1909 & 6.5 & . _do. . & 3.9 & 21.2 & 4.4 & 163 & 71 & 234 \\
\hline 15 & Aug. 10,1909 & 6. 0 & Scattering........ & 1.7 & 13. 4 & 2.7 & 98 & 43 & 141 \\
\hline 18 & .... do........ & 11.5 & .... do............ & .2 & .0 & 4. 0 & 1 & 64 & 65 \\
\hline 33 & Aug. 12, 1909 & 10.5 & ..... do ............ & .6 & 12.4 & 4. 6 & 85 & 74 & 159 \\
\hline 34 & ... do....... & 7.5 & . . do . . . . . . . . . & 4.8 & 13.3 & 3.6 & 111 & 58 & 169 \\
\hline 42 & .... do ....... & 10.5 & ... do............ & 2 & .6 & 4.5 & 5 & 72 & 77 \\
\hline 550 & Sept. 13,1909 & 6.5 & ....do. & 2.3 & 11.6 & 2.3 & 90 & 37 & 127 \\
\hline 576 & Sept. 14, 1909 & 7.5 & ..... do... & 1.8 & 9.7 & 3.1 & 75 & 50 & 125 \\
\hline 577 & .... do ....... & 8. 0 & . . do.............. & 45. 0 & 26.6 & 3.9 & 466 & 63 & 529 \\
\hline 578 & ... do....... & 11.0 & . do................ & 4. 0 & 16.3 & 4.0 & 132 & 64 & 196 \\
\hline 579 & .. do ... & 6.0 & . . do . . . . . . . . . . & 5.3 & 27.3 & 3.5 & 212 & 56 & 268 \\
\hline 5 & .... do ... & 7.5 & ....do... & 5.3 & 25.6 & 4.2 & 201 & 68 & 269 \\
\hline 581 & ..... do... & 8.5 & .....do. . & 3.4 & 15.7 & 4.9 & 124 & 79 & 203 \\
\hline 7 & Aug. 9,1909 & 10.0 & Very scattering... & 2.9 & 9.3 & 1.8 & 79 & 29 & 108 \\
\hline 21 & Aug. 10,1909 & 9.0 & . . do. do........... & .4 & 2.1 & 2.7 & 16 & 43 & 59 \\
\hline 26 & Aug. 11, 1909 & 8.5 & ...do................. & 1. 6 & 10.9 & 2.8 & 81 & 45 & 126 \\
\hline 35 & Aug. 12, 1909 & 9.5 & .... do... & .9 & 3.8 & 2.2 & 31 & 35 & 66 \\
\hline 39 & .... do ........ & 10.0 & $\ldots$ do $\ldots . . . . .$. & .2 & .4 & 2.3 & 4 & 37 & 41 \\
\hline 43 & .....do....... & 10.5 & . do.................. & .8 & 2.4 & 3.1 & 21 & 50 & 71 \\
\hline 542 & Sept. 13,1909 & 6.0 & ... do... & .0 & .8 & 1.4 & 5 & 23 & 25 \\
\hline 2 & Aug. 9,1909 & 12.0 & Depleted.. & .0 & 0 & .9 & 0 & 15 & 15 \\
\hline 5 & .... do ....... & 9.0 & .... do ..... & 3.5 & 20.0 & .9 & 153 & 15 & 168 \\
\hline 8 & ......do... & 8. 0 & ...do.. & 8. 4 & 23.9 & .6 & 210 & 10 & 220 \\
\hline 11 & Aug. 10,1909 & 8.5 & ....do... & 1.8 & 13.3 & .5 & 98 & 8 & 106 \\
\hline 12 & $\ldots$ do...... & 7. 0 & ... do... & 2.1 & 4.5 & .9 & 43 & 14 & 57 \\
\hline 13 & ... do... & 7.5 & $\ldots$ do $\ldots \ldots \ldots . . . .$. & .0 & .0 & .3 & 0 & 5 & $\mathbf{5}$ \\
\hline 16 & do.. & 12.5 & ... do... & .0 & .0 & .4 & 0 & 6 & 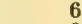 \\
\hline 25 & Aug. 11, 1909 & 10.0 & .. do... & .0 & .0 & .0 & 0 & 0 & 0 \\
\hline 36 & Aug. 12, 1909 & 10.5 & .... do do... & .5 & 1.8 & 1.3 & 8 & 21 & 29 \\
\hline 38 & .... do........ & 9.0 & ....do.... & .7 & .9 & 1.3 & 10 & 21 & 31 \\
\hline 40 & .... do... & 10.0 & . do . . . . . . . . & .4 & .7 & 1. & 7 & 19 & 26 \\
\hline 41 & do... & 10.0 & ... do. & .7 & 3.5 & 1.9 & 27 & 31 & 58 \\
\hline 547 & Sept. 13,1909 & 7.0 & ....do. . & .2 & .7 & 1.1 & 6 & 18 & 24 \\
\hline 548 & .... do do....... & 6.5 & ..... do. . & .0 & .0 & .2 & 0 & 3 & 3 \\
\hline 551 & ..... do . . & 7.5 & .....do... & 1.3 & 2.9 & .5 & 27 & 8 & 35 \\
\hline 574 & Sept. 14,1909 & 9.5 & ... do do... & .0 & .0 & .0 & 0 & 0 & 0 \\
\hline 575 & ... do....... & 9.0 & ...do. & .0 & .0 & .0 & 0 & 0 & 0 \\
\hline 583 & do... & 7.0 & .. do. & 2.6 & 10.0 & 1.1 & 82 & 18 & 100 \\
\hline 584 & ..... do... & 10.5 & ..... do.. & .0 & .0 & .0 & 0 & 0 & 0 \\
\hline 587 & . do... & 11.0 & ... do. . & .0 & .0 & .0 & 0 & 0 & 0 \\
\hline
\end{tabular}

LARKINS ROCK.

This is a small bed in Nansemond River at the extreme southwest corner of Public Ground No. 2. As developed by the survey it has an area of about 39 acres and a depth varying from $4 \frac{1}{2}$ to 8 feet at mean-low water. It is stated that the product of this bed has been in demand by shucking houses, the size and quality being generally good and the condition fat, especially early in spring. The market oysters found by the survey averaged between 300 and 350 to the bushel and the small oysters about 750 per bushel.

The bed at present bears market oysters at the average density of about 5 bushels per acre, though in spots the production is as high as 18 bushels. The young growth has an average density of about 10 bushels and a maximum of 31 bushels per acre.

At the present time this bed must be regarded as depleted, as at none of the spots examined could a man tong more than 2 bushels of oysters per day, and the average yield, taking the bed as a whole, 
would be hardly more than one-half bushel per day. The young growth is sparse and the shells few. The bed bears the aspect of having been carried off bodily for planting purposes, a depredation to which its location makes it susceptible. The results of detailed examinations are as follows:

Details of Examination of Larkins Rock.

\begin{tabular}{|c|c|c|c|c|c|c|c|c|c|}
\hline \multirow{2}{*}{$\begin{array}{c}\text { Station } \\
\text { num- } \\
\text { ber. }\end{array}$} & \multirow{2}{*}{$\begin{array}{l}\text { Date of ex- } \\
\text { amination. }\end{array}$} & \multirow{2}{*}{$\begin{array}{c}\text { Mean } \\
\text { depth } \\
\text { of wa- } \\
\text { ter. }\end{array}$} & \multirow{2}{*}{$\begin{array}{l}\text { Character of growth } \\
\text { of market oysters. }\end{array}$} & \multicolumn{3}{|c|}{$\begin{array}{l}\text { Oysters caught per } \\
\text { square yard. }\end{array}$} & \multicolumn{3}{|c|}{$\begin{array}{c}\text { Estimated quantity oys- } \\
\text { ters per acre. }\end{array}$} \\
\hline & & & & Spat. & Culls. & Counts. & Seed. & Market. & Total. \\
\hline $\begin{array}{r}20 \\
27 \\
28 \\
544 \\
545 \\
546\end{array}$ & 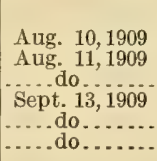 & $\begin{array}{r}\text { Feet. } \\
8.5 \\
7.5 \\
6.5 \\
6.5 \\
7.0 \\
6.5\end{array}$ & 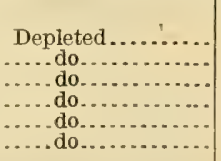 & $\begin{array}{r}0.0 \\
.0 \\
.0 \\
.0 \\
.2 \\
.0\end{array}$ & $\begin{array}{r}0.0 \\
.0 \\
3.5 \\
.0 \\
2.7 \\
.6\end{array}$ & $\begin{array}{r}0.0 \\
.0 \\
.1 \\
.0 \\
1.1 \\
.6\end{array}$ & $\begin{array}{r}\text { Bush. } \\
0 \\
0 \\
23 \\
0 \\
31 \\
4\end{array}$ & $\begin{array}{r}\text { Bush. } \\
0 \\
0 \\
2 \\
0 \\
18 \\
10\end{array}$ & $\begin{array}{r}\text { Bush. } \\
0 \\
0 \\
25 \\
0 \\
49 \\
14\end{array}$ \\
\hline
\end{tabular}

DRUM SHOAL ROCK.

This is a small bed located at the northwest corner of Public Ground No. 2 in Nansemond County. Its area, density of oyster growth, and estimated contents are as follows:

Oyster Growth on Drum Shoal Rock.

\begin{tabular}{|c|c|c|c|c|}
\hline \multirow{2}{*}{ Character of growth of market oysters. } & \multirow{2}{*}{ Area. } & \multicolumn{2}{|c|}{ Oysters per acre. } & \multirow{2}{*}{$\begin{array}{c}\text { Estimated } \\
\text { content of } \\
\text { market } \\
\text { oysters. }\end{array}$} \\
\hline & & Seed. & Market. & \\
\hline $\begin{array}{l}\text { Scattering... } \\
\text { Very scattering } \\
\text { Depleted. }\end{array}$ & $\begin{array}{r}\text { Acres. } \\
19 \\
14 \\
95\end{array}$ & $\begin{array}{r}\text { Bushels. } \\
92 \\
61 \\
62\end{array}$ & $\begin{array}{r}\text { Bushels. } \\
50 \\
39 \\
29\end{array}$ & $\begin{array}{r}\text { Bushels. } \\
950 \\
546 \\
2,755\end{array}$ \\
\hline Total.. & 128 & & & 4,251 \\
\hline
\end{tabular}

This bed was doubtless originally restricted to the area of the shoal which is now covered by the scattering and very scattering growth, but oysters and shells have become scattered over the surrounding bottom and it is now connected, by means of a depleted area, with Nansemond Ridge Rock on the south and Newport News Rock on the west.

The scattering growth lies in a depth of from 6 to 8 feet at mean low water and the market oysters grow in such quantity that a tonger of average ability can take about 5 bushels per day. The very scattering growth is at the eastern side of the shoal and has oysters in sufficient numbers to yield about $3 \frac{1}{2}$ bushels per day. The density of growth shown for the depleted area in the table produced above is in excess of the actual conditions, as the examina- 
tions on which it was based were taken in close proximity to the edge of the shoal, while the more distant bottom is more denuded. The growth of young on the productive part of the rock is fair, being sufficient to yield about 9 bushels per day on the scattered area and about 6 bushels on the very scattered area and about the edges of the shoal.

Following is the record of observations on this bed:

Detalls of Examination of Drum Shoal Rock.

\begin{tabular}{|c|c|c|c|c|c|c|c|c|c|}
\hline \multirow{2}{*}{$\begin{array}{c}\text { Station } \\
\text { num- } \\
\text { ber. }\end{array}$} & \multirow{2}{*}{$\begin{array}{l}\text { Date of ex- } \\
\text { amination. }\end{array}$} & \multirow{2}{*}{$\begin{array}{l}\text { Mean } \\
\text { depth } \\
\text { of wa. } \\
\text { ter. }\end{array}$} & \multirow{2}{*}{$\begin{array}{l}\text { Character of growth } \\
\text { of market oysters. }\end{array}$} & \multicolumn{3}{|c|}{$\begin{array}{l}\text { Oysters caught per } \\
\text { square yard. }\end{array}$} & \multicolumn{3}{|c|}{$\begin{array}{l}\text { Estimated quantity oys- } \\
\text { ters per acre. }\end{array}$} \\
\hline & & & & Spat. & Culls. & Counts. & Seed. & Market. & Total. \\
\hline $\begin{array}{r}585 \\
586 \\
44 \\
45\end{array}$ & $\begin{array}{l}\text { Sept. 14,1909 } \\
\text { Aug. } 12,1909 \\
\text {....do......... }\end{array}$ & $\begin{array}{r}\text { Feet. } \\
8.0 \\
9.0 \\
10.5 \\
8.5\end{array}$ & $\begin{array}{l}\text { Scattering ........... } \\
\text { Very scattering .... } \\
\text { Depleted............. } \\
\ldots . . . \text { do ................. }\end{array}$ & $\begin{array}{r}2.6 \\
1.5 \\
.7 \\
.9\end{array}$ & $\begin{array}{r}11.6 \\
7.9 \\
6.1 \\
12.0\end{array}$ & $\begin{array}{l}3.1 \\
2.4 \\
1.9 \\
1.7\end{array}$ & $\begin{array}{r}\text { Bush. } \\
92 \\
61 \\
44 \\
84\end{array}$ & $\begin{array}{r}\text { Bush. } \\
50 \\
39 \\
31 \\
27\end{array}$ & $\begin{array}{r}\text { Bush. } \\
142 \\
100 \\
75 \\
111\end{array}$ \\
\hline
\end{tabular}

\section{NEWPORT NEWS ROCK.}

This lies in the overlapping portions of Public Grounds No. 2, Nansemond County, and No. 6, Isle of Wight County, north of Nansemond Ridge, and between Drum Shoal on the east and Cruiser Rock on the west. Its estimated area, density of growth, and contents are as follows:

Oyster Growth on Newport News Rock.

\begin{tabular}{|c|c|c|c|c|}
\hline \multirow{2}{*}{ Character of growth of market oysters. } & \multirow{2}{*}{ Area. } & \multicolumn{2}{|c|}{ Oysters per acre. } & \multirow{2}{*}{$\begin{array}{l}\text { Estimated } \\
\text { content of } \\
\text { market } \\
\text { oysters. }\end{array}$} \\
\hline & & Seed. & Market. & \\
\hline 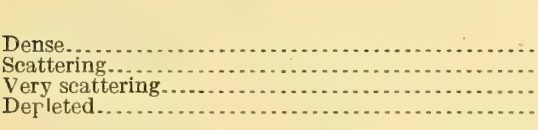 & $\begin{array}{r}\text { Acres. } \\
4 \\
27 \\
12 \\
129 \\
\end{array}$ & $\begin{array}{r}\text { Bushels. } \\
93 \\
75 \\
83 \\
34 \\
\end{array}$ & $\begin{array}{r}\text { Bushels. } \\
108 \\
63 \\
35 \\
27 \\
\end{array}$ & $\begin{array}{r}\text { Bushels. } \\
432 \\
1,701 \\
420 \\
3,483\end{array}$ \\
\hline Total... & 172 & & & 6,036 \\
\hline
\end{tabular}

The rock in reality consists of several shoal spots separated by areas of depleted bottom in deeper water. The dense area is a small spot lying by itself in about 8 feet of water at low tide, and it bears market oysters in sufficient quantity to yield to the tonger about 9 bushels per day, and the young growth is in nearly the same quantity. The scattered and very scattered growth lies on Cruiser Shoal proper, the former being sufficiently productive to yield about 6 bushels and the latter about 3 bushels per day. On both of these areas there is a fair growth of young, sufficient to yield about 6 bushels per day. 
At the eastern edge of the rock, as defined on the chart, there is a dense growth, not shown, which lies just outside of the Baylor line, and running south from this is a growth of young oysters on the so-called depleted bottom sufficient to yield about 4 bushels per day. The depleted bottom on the whole will yield about 2 bushels of market oysters per day and about the same quantity of young.

The following are the results of examinations on this rock:

Detalls of Examination of Newport News Rock.

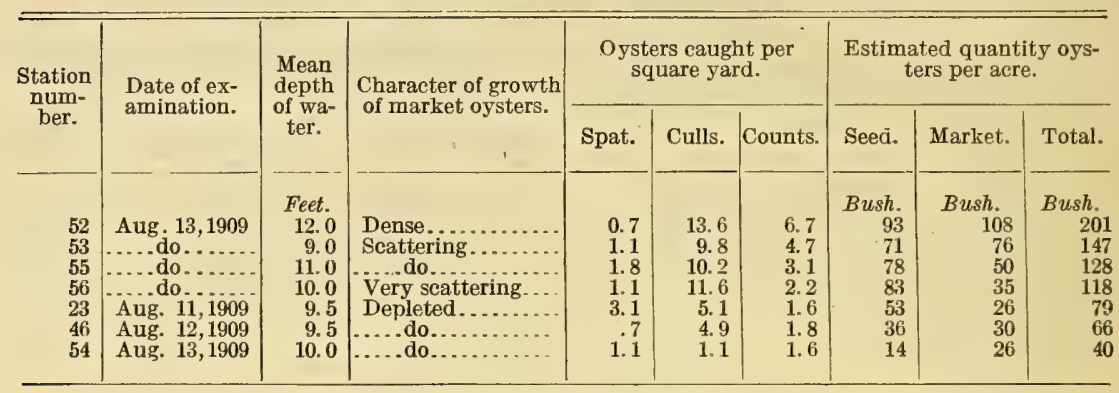

CRUISER SHOAL ROCK.

This rock lies on and about the shoal that gives it its name, mainly in Public Ground No. 6, Warwick County, but partly in the area common to that ground and No. 2, Nansemond County. Its area and condition are shown in the following table:

Oyster Growth on Cruiser Shoal Rock.

\begin{tabular}{|c|c|c|c|c|}
\hline \multirow{2}{*}{ Character of growth of market oysters. } & \multirow{2}{*}{ Area. } & \multicolumn{2}{|c|}{ Oysters per acre. } & \multirow{2}{*}{$\begin{array}{l}\text { Estimated } \\
\text { content of } \\
\text { market } \\
\text { oysters. }\end{array}$} \\
\hline & & Seed. & Market. & \\
\hline 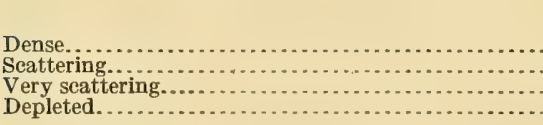 & $\begin{array}{r}\text { Acres. } \\
27 \\
19 \\
26 \\
32\end{array}$ & $\begin{array}{r}\text { Bushels. } \\
140 \\
47 \\
51 \\
66\end{array}$ & $\begin{array}{r}\text { Bushels. } \\
156 \\
53 \\
28 \\
9\end{array}$ & $\begin{array}{r}\text { Bushels. } \\
4,212 \\
1,007 \\
728 \\
288\end{array}$ \\
\hline Total.... & 104 & & & 6,235 \\
\hline
\end{tabular}

The dense and scattered areas follow the line of a very shallow ridge which forms the backbone of the shoal, the former being capable of yielding from 10 to 20 bushels of oysters per day and the latter about 5 . The area of very scattering growth lies on each side of the more prolific areas and is capable of yielding about 3 bushels of market oysters per day's tonging. The depleted area will yield an average of not over 1 bushel of market oysters per day, and the parts more distant from the ridge are practically bare. Close to the ridge, even on some of the bottom depleted of market oysters, the 
growth of young is good enough to yield an average of about 15 bushels per day to the tonger; but on the very scattering and depleted areas further removed from the ridge the young growth is sparse.

The following table shows the results of the examinations made on this bed:

Details of Examination of Cruiser Shoal Rock.

\begin{tabular}{|c|c|c|c|c|c|c|c|c|c|}
\hline \multirow{2}{*}{$\begin{array}{c}\text { Station } \\
\text { num- } \\
\text { ber. }\end{array}$} & \multirow{2}{*}{$\begin{array}{l}\text { Date of ex- } \\
\text { amination. }\end{array}$} & \multirow{2}{*}{$\begin{array}{c}\text { Mean } \\
\text { depth } \\
\text { of wa- } \\
\text { ter. }\end{array}$} & \multirow{2}{*}{$\begin{array}{l}\text { Character of growth } \\
\text { of market oysters. }\end{array}$} & \multicolumn{3}{|c|}{$\begin{array}{l}\text { Oysters caught per } \\
\text { square yard. }\end{array}$} & \multicolumn{3}{|c|}{$\begin{array}{l}\text { Estimated quantity oys- } \\
\text { ters per acre. }\end{array}$} \\
\hline & & & & Spat. & Culls. & Counts. & Seed. & Market. & Total. \\
\hline $\begin{array}{r}58 \\
589 \\
51 \\
50 \\
57 \\
47 \\
59 \\
590\end{array}$ & $\begin{array}{l}\text { Aug. 13,1909 } \\
\text { Sept. 14,1909 } \\
\text { Aug. 12,1909 } \\
\text { Aug. do. 13, } 1909 \\
\text { Aug. 12,1909 } \\
\text { Aug. 13,1909 } \\
\text { Sept. 14,1909 }\end{array}$ & $\begin{array}{r}\text { Feet. } \\
10.5 \\
8.5 \\
9.0 \\
11.0 \\
7.5 \\
9.0 \\
13.0 \\
6.0\end{array}$ & 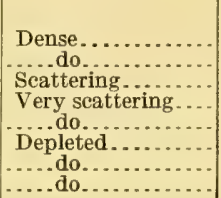 & $\begin{array}{r}4.0 \\
1.5 \\
.3 \\
.2 \\
1.8 \\
.5 \\
.0 \\
5.3\end{array}$ & $\begin{array}{r}21.0 \\
17.0 \\
7.0 \\
.4 \\
13.4 \\
4.5 \\
.0 \\
20.2\end{array}$ & $\begin{array}{r}7.3 \\
12.1 \\
3.3 \\
2.0 \\
1.6 \\
.7 \\
.0 \\
.9\end{array}$ & $\begin{array}{r}\text { Bush. } \\
162 \\
120 \\
47 \\
4 \\
99 \\
32 \\
0 \\
166\end{array}$ & $\begin{array}{r}\text { Bush. } \\
117 \\
195 \\
53 \\
32 \\
25 \\
11 \\
0 \\
15\end{array}$ & $\begin{array}{r}\text { Bush. } \\
279 \\
315 \\
100 \\
36 \\
124 \\
43 \\
0 \\
181\end{array}$ \\
\hline
\end{tabular}

\section{FLAT ROCK AND ADJACENT SMALL BEDS.}

Flat Rock is a small bed bearing a dense growth of market oysters lying in the southeast corner of Public Ground No.6, Warwick County. The examination of this rock was not satisfactory, as owing to an error in platting in the field certain positions supposed to be on the bed proved to be on adjacent planted beds. The single examination, in connection with traversing lines of chain readings, indicates a growth over the entire area which will yield to the tonger an average of about 9 bushels of market oysters per day. There were practically no small oysters or shells, and there was some reason to believe that the place had been planted, though it was fully 200 yards inside of the Baylor lines.

North of Flat Rock is a small depleted area, covering about 7 acres, on which there are about 26 bushels of market oysters and 16 bushels of young oysters per acre, and on which it is computed that a tonger could take not over 2 bushels of oysters per day.

West of Cruiser Rock is another unnamed bed of very scattering oysters. Its area is about 5 acres, with an average of 42 bushels of market oysters and 55 bushels of seed oysters per acre, and it is estimated that a tonger could take about $3 \frac{1}{2}$ bushels of oysters per day.

Northwest of Flat Rock, at intervals of about 400 yards, are two small beds where the water does not shoal, on which no determinations were made except with the chain. The indications are of very scattering growths. The areas are about 5 and 2 acres, respectively. The data relating to the several beds examined are as follows: 
Detams of Examination of Flat Rock and Small Beds Between Nansemond Ridge and Fishing Point.

\begin{tabular}{|c|c|c|c|c|c|c|c|c|c|}
\hline \multirow{2}{*}{$\begin{array}{c}\text { Station } \\
\text { num- } \\
\text { ber. }\end{array}$} & \multirow{2}{*}{$\begin{array}{l}\text { Date of ex- } \\
\text { amination. }\end{array}$} & \multirow{2}{*}{$\begin{array}{l}\text { Mean } \\
\text { depth } \\
\text { of wa- } \\
\text { ter. }\end{array}$} & \multirow{2}{*}{$\begin{array}{l}\text { Character of growth } \\
\text { of market oysters. }\end{array}$} & \multicolumn{3}{|c|}{$\begin{array}{l}\text { Oysters caught per- } \\
\text { square yard. }\end{array}$} & \multicolumn{3}{|c|}{$\begin{array}{l}\text { Estimated quantity oys- } \\
\text { ters per acre. }\end{array}$} \\
\hline & & & & Spat. & Culls. & Counts. & Seed. & Market. & Total. \\
\hline $\begin{array}{l}31 \\
48 \\
32\end{array}$ & $\begin{array}{l}\text { Aug. 11, } 1909 \\
\text { Aug. 12,1909 } \\
\text { Aug. 11, } 1909\end{array}$ & $\begin{array}{l}\text { Feet. } \\
10.5 \\
10.0 \\
10.5\end{array}$ & $\begin{array}{l}\text { Dense............. } \\
\text { Very scattering.... } \\
\text { Depleted........... }\end{array}$ & $\begin{array}{r}0.2 \\
1.8 \\
.0\end{array}$ & $\begin{array}{l}0.2 \\
6.7 \\
2.4\end{array}$ & $\begin{array}{l}6.7 \\
2.6 \\
1.6\end{array}$ & $\begin{array}{r}\text { Bush. } \\
3 \\
55 \\
16\end{array}$ & $\begin{array}{r}\text { Bush. } \\
108 \\
42 \\
26\end{array}$ & $\begin{array}{r}\text { Bush. } \\
111 \\
97 \\
42\end{array}$ \\
\hline
\end{tabular}

HIGH SHOAL ROCK.

High Shoal Rock is conspicuous from its position, near the middle of James River, surrounding a shoal of sand and broken shells bare at practically all times. The highest part of the shoal is near the channel, from which it extends shoreward toward Fishing Point. The bed, including the depleted parts, is quadrangular in shape, with its more productive areas extending at right angles to the shores along its major diameter. Its extent and density of growth are as follows:

Oyster Growth on High Shoal Rock.

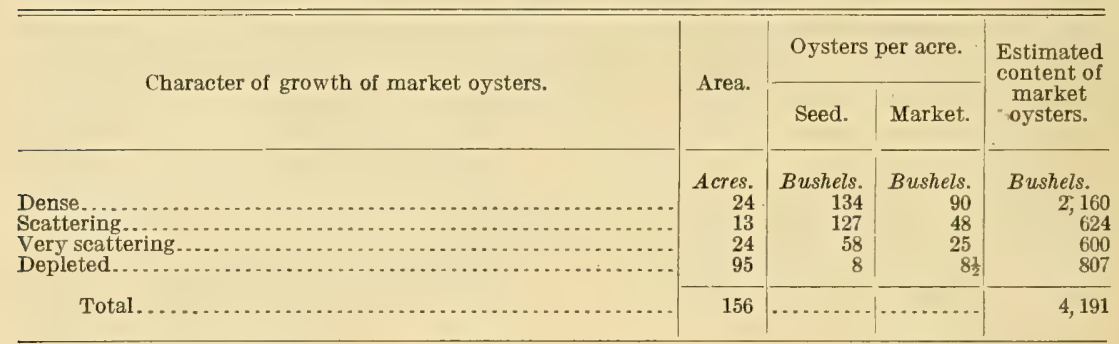

The dense area extends along practically the entire length of the shoal, as a narrow strip on both sides but especially to the eastward of the highest ridge. The market oysters are somewhat smaller than those in water a little deeper, but on the bed as a whole they were found to average about 400 to the bushel. It is estimated that on this area a tonger could take about 10 bushels of oysters per day.

The area of scattering growth forms a strip on the southern side of the bed along the edge of a deep swash channel which separates it from one of the neighboring Fishing Point Rocks. Market oysters are produced in sufficient abundance to yield the tonger akout $6 \frac{1}{2}$ bushels per day. The very scattering area lies to the eastward of the dense area and north of the scattering, and produces oysters sufficient to furnish the tonger about 3 to $3 \frac{1}{2}$ bushels per day. 
The depleted area, which constitutes the major portion of the bed as delineated on the chart, is principally on the western or upstream side, though a strip averaging about 100 yards in width extends around the outer end of the shoal and along its entire eastern side. This area will nowhere yield to the tonger more than about $2 \frac{1}{2}$ bushels of oysters per day, and the average yield of all places examined would not be over 1 bushel.

The growth of young oysters on the areas charted as dense and scattering and on the very scattering part closer to the ridge is prolific enough to yield a tonger from 8 to 25 bushels per day, the average of all places examined being about 17 bushels. Clean shells were abundant on the three productive areas and in the depleted area close to the ridge.

The data on which the foregoing statements are based is as follows:

Details of Examination of High Shoal Rock.

\begin{tabular}{|c|c|c|c|c|c|c|c|c|c|}
\hline \multirow{2}{*}{$\begin{array}{c}\text { Station } \\
\text { num- } \\
\text { ber. }\end{array}$} & \multirow{2}{*}{$\begin{array}{l}\text { Date of ex- } \\
\text { amination. }\end{array}$} & \multirow{2}{*}{$\begin{array}{c}\text { Mean } \\
\text { depth } \\
\text { of wa- } \\
\text { ter. }\end{array}$} & \multirow{2}{*}{$\begin{array}{l}\text { Character of growth } \\
\text { of market oysters. }\end{array}$} & \multicolumn{3}{|c|}{$\begin{array}{l}\text { Oysters caught per } \\
\text { square yard. }\end{array}$} & \multicolumn{3}{|c|}{$\begin{array}{c}\text { Estimated quantity oys- } \\
\text { ters per acre. }\end{array}$} \\
\hline & & & & Spat. & Culls. & Counts. & Seed. & Market. & Total. \\
\hline & & Feet. & & & & & Bush. & Bush. & Bush. \\
\hline $\begin{array}{l}68 \\
70\end{array}$ & Aug. 13,1909 & $\begin{array}{l}7.0 \\
7.5\end{array}$ & Dense. & $\begin{array}{r}3.6 \\
10.0\end{array}$ & $\begin{array}{l}10.9 \\
17.0\end{array}$ & $\begin{array}{r}7.8 \\
10.3\end{array}$ & $\begin{array}{r}94 \\
175\end{array}$ & $\begin{array}{r}94 \\
125\end{array}$ & $\begin{array}{l}188 \\
300\end{array}$ \\
\hline 473 & Sept. 7,1909 & 5.5 & do & 3.2 & 12.4 & 2.6 & 101 & 32 & 132 \\
\hline 474 & ..... do ......... & 6.0 & ...... do. & 3.2 & 22.5 & 8. & 167 & 102 & 269 \\
\hline 67 & Aug. 13,1909 & 6.0 & Scattering. & 3. & 26. & 4. & 194 & 50 & 244 \\
\hline 478 & Sept. 8,1909 & 6.0 & .....do.. & 2.9 & 6.5 & 3. & 61 & 47 & 108 \\
\hline 476 & . . do ......... & 8. 0 & Very scattering. & .0 & .3 & 2.9 & 2 & 35 & 37 \\
\hline 477 & & 3.5 & & 7.6 & 10.1 & 1.3 & 115 & 16 & 131 \\
\hline 63 & Aug. 13,1909 & 14.5 & Depleted & .0 & .0 & 0 & 0 & 0 & 0 \\
\hline 64 & ..... do........ & 12.5 & ...... do... & .0 & .2 & 1.8 & 1 & 22 & 23 \\
\hline 69 & ..... do .......... & 9.0 & ......do.. & .0 & .0 & & 0 & 0 & 0 \\
\hline 71 & .. do... & 7.5 & $\ldots . d$ & .4 & 2.2 & 1.8 & 17 & 22 & 39 \\
\hline 470 & Sept. 7,1909 & 4.0 & ... do & 2.4 & 1.8 & .2 & 27 & 2 & 29 \\
\hline 471 & $\ldots$ do $0 . .$. . & 6.0 & . do & 1.1 & .1 .4 & 1. & 16 & 20 & 36 \\
\hline 472 & do... & 6.5 & ..... do $\ldots . . .$. & .0 & 1.0 & 1.7 & 6 & 20 & 26 \\
\hline 479 & Sept. 8,1909 & 7.5 & .... do ............. & .0 & .2 & .0 & 1 & 0 & 1 \\
\hline 480 & ..... do ...... & 9. & .. d & .0 & 1.3 & .0 & 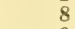 & 0 & 8 \\
\hline 481 & .... do ... & 7.0 & .. do. & .0 & .0 & .0 & 0 & 0 & 0 \\
\hline
\end{tabular}

TROUT SHOAL ROCK.

This bed occupies the southeastern part of Naseway Shoal. In its depleted area it is continuous with Dog Shoal Rock, which occupies the upper part of the same shoal, but is separated from the adjacent Fishing Point and High Shoal Rocks'by swash channels in which there is an abrupt deepening of the water. The depth ranges from low-water mark to 10 or 11 feet, the greater depths being found in a pocket of deep water which extends far into Naseway shoal from the westward. 
The extent and productiveness of the bed are shown in the following table:

Oyster Growth on Trout Shoal Rock.

\begin{tabular}{|c|c|c|c|c|}
\hline \multirow{2}{*}{ Character of growth of market oysters. } & \multirow{2}{*}{ Area. } & \multicolumn{2}{|c|}{ Oysters per acre. } & \multirow{2}{*}{$\begin{array}{l}\text { Estimated } \\
\text { content of } \\
\text { market } \\
\text { oysters. }\end{array}$} \\
\hline & & Seed. & Market. & \\
\hline $\begin{array}{l}\text { Scattering } \\
\text { Very scattering } \\
\text { Depleted }\end{array}$ & $\begin{array}{r}\text { Acres. } \\
25 \\
14 \\
90\end{array}$ & $\begin{array}{r}\text { Bushels. } \\
165 \\
118 \\
21\end{array}$ & $\begin{array}{r}\text { Bushels. } \\
44 \\
30 \\
8\end{array}$ & $\begin{array}{r}\text { Bushels. } \\
1,100 \\
420 \\
720\end{array}$ \\
\hline Total.. & 129 & & & 2,240 \\
\hline
\end{tabular}

There is no dense growth within the meaning of the definition adopted in this report-that is, bottom on which 8 or more bushels of market oysters may be tonged by a man working 9 hours. There are two areas of scattering growth which lie as strips along the line of a shoal largely exposed at low water. These areas are sufficiently productive to yield from 5 to 10 bushels of market oysters per day to the tonger, the average being about 7 bushels.

The only other productive bottom is a very scattering area occupying the central and eastern portion of the rock, from the ridge to the deep water lying between this shoal and High Shoal. On this area a tonger can average a little over 3 bushels of oysters per day. Depleted areas lie on each side of the shoal, that on the western side being more extensive and continuous with the depleted area of Dog Shoal rock. On these areas a tonger could take hardly a bushel of market oysters per day, although there are spots a little more productive. On the scattering and very scattering areas of market oysters the young growth is prolific, on the former being sufficient to yield to the tonger an average of about 26 bushels per day and on the latter about 16 bushels. On both of these areas there is an abundance of clean shells suitable for taking a set of spat, but the depleted areas have comparatively few shells and young oysters.

The following observations were made on this rock:

Details of Examination of Trout Shoal Rock.

\begin{tabular}{|c|c|c|c|c|c|c|c|c|c|}
\hline \multirow{2}{*}{$\begin{array}{c}\text { Station } \\
\text { num- } \\
\text { ber. }\end{array}$} & \multirow{2}{*}{$\begin{array}{l}\text { Date of ex- } \\
\text { amination. }\end{array}$} & \multirow{2}{*}{$\begin{array}{c}\text { Mean } \\
\text { depth } \\
\text { of wa- } \\
\text { ter. }\end{array}$} & \multirow{2}{*}{$\begin{array}{l}\text { Character of growth } \\
\text { of market oysters. }\end{array}$} & \multicolumn{3}{|c|}{$\begin{array}{l}\text { Oysters caught per } \\
\text { square yard. }\end{array}$} & \multicolumn{3}{|c|}{$\begin{array}{l}\text { Estimated quantity oys- } \\
\quad \text { ters per acre. }\end{array}$} \\
\hline & & & & Spat. & Culls. & Counts. & Seed. & Market. & Total. \\
\hline & & Feet. & & & & & Bush. & Bush. & Bush. \\
\hline $\begin{array}{r}76 \\
105\end{array}$ & $\begin{array}{l}\text { Aug. } 13,1909 \\
\text { Aug. } 14,1909\end{array}$ & $\begin{array}{l}6.5 \\
4.0\end{array}$ & Scattering............. & $\begin{array}{l}7.7 \\
1.0\end{array}$ & $\begin{array}{l}32.3 \\
16.1\end{array}$ & $\begin{array}{l}4.0 \\
2.4\end{array}$ & $\begin{array}{l}260 \\
111\end{array}$ & $\begin{array}{l}48 \\
29\end{array}$ & $\begin{array}{l}308 \\
140\end{array}$ \\
\hline 482 & Sept. 8,1909 & 4.5 & do. & 4. & 29.1 & 4. & 220 & 59 & 279 \\
\hline 488 & .... do........ & 6.5 & do. & 4.2 & 21.6 & 3. & 168 & 41 & 209 \\
\hline 75 & Aug. 13, 1909 & 6.0 & Very scattering... & 4.3 & 18.3 & 2. & 147 & 24 & 171 \\
\hline 106 & Aug. 14, 1909 & 5. 0 & .... do... . . . & .8 & 25.6 & 1.8 & 171 & 22 & 193 \\
\hline 107 & .... do........ & 10.0 & .... do.... & .4 & 18.7 & 3. & 124 & 40 & 164 \\
\hline 108 & $\ldots$ do........ & 9.5 & ..... do. & .0 & 4.8 & 2. & 31 & 34 & 65 \\
\hline 72 & Aug. 13, 1909 & 11.5 & Depleted......... & .4 & 2.1 & 1.7 & 16 & 21 . & 37 \\
\hline 483 & Sept. 8,1909 & 11.0 & .... do.... & .7 & 2.3 & .3 & 19 & 4 & 23 \\
\hline 484 & .... do...... & 5. 5 & .....do... & 1. 6 & 6.1 & .6 & 50 & 7 & 57 \\
\hline 487 & ......do... & 6.5 & ..... do. . & .0 & .0 & .0 & 0 & 0 & 0 \\
\hline
\end{tabular}


DOG SHOAL ROCK.

This bed occupies the northwestern or upstream part of Naseway Shoal. The rocks are in reality two, separated by the tongue of deeper water which makes into Naseway Shoal from the west and extends well toward the ridge of Trout Shoal.

The larger rock is hook shaped and contains two areas of dense growth and a long strip of very scattering oysters, both following the line of a shell ridge bare in parts at low water. The smaller area is a $U$-shaped ridge of scattering oysters lying between the deeper water just mentioned and the swash channel, which separates it from the adjacent Fishing Point rock.

The following table shows the area, density of growth, and estimated oyster content of the rock:

\section{Oyster Growth on Dog Shoal Rock.}

\begin{tabular}{|c|c|c|c|c|}
\hline \multirow{2}{*}{ Character of growth of market oysters. } & \multirow{2}{*}{ Area. } & \multicolumn{2}{|c|}{ Oysters per acre. } & \multirow{2}{*}{$\begin{array}{l}\text { Estimated } \\
\text { content of } \\
\text { market } \\
\text { oysters. }\end{array}$} \\
\hline & & Seed. & Market. & \\
\hline 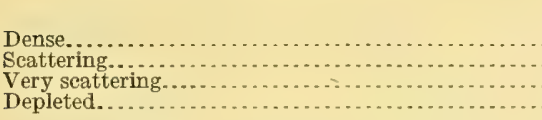 & $\begin{array}{r}\text { Acres. } \\
16 \\
13 \\
35 \\
118\end{array}$ & $\begin{array}{r}\text { Bushels. } \\
155 \\
153 \\
22 \\
41\end{array}$ & $\begin{array}{r}\text { Bushels. } \\
104 \\
39 \\
27 \\
12\end{array}$ & $\begin{array}{r}\text { Bushels. } \\
1,664 \\
507 \\
945 \\
1,416\end{array}$ \\
\hline Total... & 182 & & & 4,532 \\
\hline
\end{tabular}

The dense areas produce market oysters in sufficient quantity to yield the tonger an average of about 12 bushels per day, the scattering area will yield about 6 bushels, and the very scattering about 3 bushels. On the depleted area the yield would be at no place more than about 2 or $2 \frac{1}{2}$ bushels of marketable stock, and the average at all places examined was about 1 bushel.

The growth of young oysters on this rock is prolific, the density on the dense and scattering areas of market oysters being sufficient to yield the tonger an average of about 23 bushels per day. On the area of very scattering growth the yield should be about 3 bushels of young per day and on the depleted area about 4 bushels. The average of the latter is brought up by the very dense growth of young found in places close to the exposed ridge, where the quantity of market oysters was negligible. Over all of the area shown on the chart as depleted, excepting close to the productive areas, both clean shells and young were practically absent. The market oysters on this rock, like those on Trout Shoal and High Shoal, are comparatively small, averaging a little in-excess of 400 per bushel.

The data on which the foregoing description is based are as follows: 
Details of Examination of Dog Shoal Rock.

\begin{tabular}{|c|c|c|c|c|c|c|c|c|c|}
\hline \multirow{2}{*}{$\begin{array}{c}\text { Station } \\
\text { num- } \\
\text { ber. }\end{array}$} & \multirow{2}{*}{$\begin{array}{l}\text { Date of ex- } \\
\text { amination. }\end{array}$} & \multirow{2}{*}{$\begin{array}{c}\text { Mean } \\
\text { depth } \\
\text { of wa- } \\
\text { ter. }\end{array}$} & \multirow{2}{*}{$\begin{array}{l}\text { Character of growth } \\
\text { of market oysters. }\end{array}$} & \multicolumn{3}{|c|}{$\begin{array}{l}\text { Oysters caught per } \\
\text { square yard. }\end{array}$} & \multicolumn{3}{|c|}{$\begin{array}{c}\text { Estimated quantity oys- } \\
\text { ters per acre. }\end{array}$} \\
\hline & & & & Spat. & Culls. & Counts. & Seed. & Market. & Total. \\
\hline & & Feet. & & & & & Bush. & Bush. & Bush. \\
\hline 79 & Aug. 13, 1909 & 7.0 & Dense............ & 10. 2 & 30.3 & 9.1 & 263 & 110 & 373 \\
\hline 103 & Aug. 14,1909 & 5.5 & . . . do ........... & 3.7 & 21.0 & 6.0 & 160 & 73 & 233 \\
\hline 104 & $\ldots$ do........ & 5.5 & .....do.. & 4. 2 & 21.2 & 3.0 & 165 & 36 & 201 \\
\hline 491 & Sept. 8, 1909 & 6.0 & ..... do ............. & 7.4 & 21.3 & 16. 0 & 187 & 194 & 381 \\
\hline 493 & ... do...... & 9.5 & .... do do............ & .0 & .0 & 9.0 & 0 & 109 & 109 \\
\hline 102 & Aug. 14, 1909 & 4.5 & Scattering . . . . . . . . & 1.2 & 15. 2 & 2.4 & 106 & 29 & 135 \\
\hline 465 & Sept. 3,1909 & 6.0 & ... do............ & 9.2 & 21.7 & 4.1 & 201 & 49 & 250 \\
\hline 78 & Aug. 13, 1909 & 4. 0 & Very scattering... & 2.4 & 3.2 & 1.0 & 36 & 12 & 48 \\
\hline 486 & Sept. 8, 1909 & 8.0 & ... do . . . . . . & .0 & 4.5 & 2.7 & 29 & 33 & 62 \\
\hline 492 & ... do =...... & 8.5 & ..... do . ............ & .0 & 2.0 & 3.0 & 13 & 36 & 49 \\
\hline 494 & .... do ....... & 7.0 & . . do . . . . . . . . & .0 & .0 & 2.1 & 0 & 25 & 25 \\
\hline 496 & ... . do....... & 6.5 & . . do ............ & .6 & 3.0 & 2.4 & 23 & 29 & 53 \\
\hline 77 & Aug. 13,1909 & 7.5 & Depleted.......... & 4.1 & 11.0 & 1.6 & 98 & 19 & 117 \\
\hline 82 & .... do...... & 5.5 & .... do ............... & 6.4 & 42.1 & 1.3 & 302 & 16 & 318 \\
\hline 83 & ... do...... & 9.0 & .... do... & .3 & .0 & 2.3 & 2 & 28 & 30 \\
\hline 101 & Aug. 14, 1909 & 10.0 & .... do... & .0 & .3 & .7 & 2 & 8 & 10 \\
\hline 485 & Sept. 8,1909 & 11.5 & ..... do do............ & .0 & .3 & 2.3 & 2 & 28 & 30 \\
\hline 487 & . . . do....... & 6.5 & .... do............... & .0 & .0 & .0 & 0 & 0 & \\
\hline 490 & .... do...... & 8.5 & ... do......... & .0 & .0 & 1.7 & 0 & 21 & 21 \\
\hline 495 & $\therefore$ do ....... & 7.0 & .....do............. & .0 & .3 & .0 & 2 & 0 & 2 \\
\hline 500 & ..... do... & 6.5 & ... do . . . & .0 & .3 & .0 & 2 & 0 & 2 \\
\hline 501 & ..... do... & 6.5 & $\therefore$ do... & .0 & .0 & .0 & 0 & 0 & 0 \\
\hline
\end{tabular}

FISHING POINT ROCKS.

These are two beds of considerable extent lying between High Shoal and Naseway Shoal and Fishing Point. The names by which they are known to the oystermen were not learned. One of these beds, embracing scattered and very scattered areas, lies between High Shoal and the Baylor line, almost surrounded by deeper water; the other, which includes dense, scattered, and depleted areas, lies along the Baylor line inside of Naseway Shoal, from which it is separated by a channel carrying from 8 to 10 feet at low water.

The statistics of the rocks are as follows:

Oyster Growth on Fishing Point Rocks.

\begin{tabular}{|c|c|c|c|c|}
\hline \multirow{2}{*}{ Character of growth of market oysters. } & \multirow{2}{*}{ Area. } & \multicolumn{2}{|c|}{ Oysters per acre. } & \multirow{2}{*}{$\begin{array}{l}\text { Estimated } \\
\text { content of } \\
\text { market } \\
\text { oysters. }\end{array}$} \\
\hline & & Seed. & Market. & \\
\hline 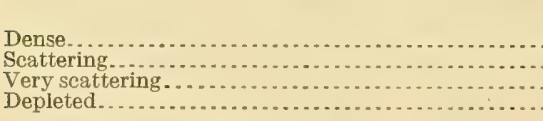 & $\begin{array}{r}\text { Acres. } \\
45 \\
77 \\
47 \\
90\end{array}$ & $\begin{array}{r}\text { Bushels. } \\
185 \\
178 \\
70 \\
30\end{array}$ & $\begin{array}{r}\text { Bushels. } \\
119 \\
82 \\
44 \\
19\end{array}$ & $\begin{array}{r}\text { Bushels. } \\
5,355 \\
6,314 \\
2,068 \\
1,710\end{array}$ \\
\hline Total...... & 259 & & & 15,447 \\
\hline
\end{tabular}

It is estimated that on the dense area a tonger could take an average of 10 or 11 bushels of market oysters per day, and on the scattering area about 7 bushels. On the very scattering area the water is rather deep, the beds in this vicinity ranging from about 12 to 22 feet at low water, and although the density of growth is fair as compared with other beds described, this reduces the probable yield to the tonger to an average of between 3 and 4 bushels per day. On the depleted 
area the probable average yield is estimated at between $1 \frac{1}{2}$ and 2 bushels per day of tonging. On the area of scattering growth on the bed inside of High Shoal young growth is almost absent, giving the bottom the appearance of having been planted. On the very scattering area in the same bed the quantity of young is sufficient to yield about 6 bushels per day per tonger.

On the dense and scattering areas of the other bed there is a dense growth of young oysters, sufficient to yield on the former about 18 bushels and on the latter about 13 bushels per day. On the depleted bottom as a whole it would probably be impossible to take more than 3 bushels of young per day, though there are spots where the yield might be double that amount.

The following results were obtained from examinations:

Detalls of Examination of Fishing Point Rocks.

\begin{tabular}{|c|c|c|c|c|c|c|c|c|c|}
\hline \multirow{2}{*}{$\begin{array}{c}\text { Station } \\
\text { num- } \\
\text { ber. }\end{array}$} & \multirow{2}{*}{$\begin{array}{l}\text { Date of ex- } \\
\text { amination. }\end{array}$} & \multirow{2}{*}{$\begin{array}{c}\text { Mean } \\
\text { depth } \\
\text { of wa- } \\
\text { ter. }\end{array}$} & \multirow{2}{*}{$\begin{array}{l}\text { Character of growth } \\
\text { of market oysters. }\end{array}$} & \multicolumn{3}{|c|}{$\begin{array}{l}\text { Oysters caught per } \\
\text { square yard. }\end{array}$} & \multicolumn{3}{|c|}{$\begin{array}{l}\text { Estimated quantity oys- } \\
\text { ters per acre. }\end{array}$} \\
\hline & & & & Spat. & Culls. & Counts. & Seed. & Market. & Total. \\
\hline 466 & Sept. 3, 1909 & $\begin{array}{l}\text { Feet. } \\
8.0\end{array}$ & Dens & 3.8 & 27.4 & 8.5 & $\begin{array}{r}\text { Bush. } \\
203\end{array}$ & Bush. & Bush. \\
\hline 467 & ...... do........ & $\begin{array}{l}8.0 \\
8.0\end{array}$ & .....do. & $\begin{array}{l}0.0 \\
1.2\end{array}$ & 24.7 & 11.2 & $\begin{array}{l}200 \\
168\end{array}$ & 135 & $\begin{array}{l}500 \\
303\end{array}$ \\
\hline 62 & Aug. 13, 1909 & 14.0 & Scattering. & .0 & .3 & 6.7 & 2 & 81 & 83 \\
\hline 468 & Sept. 3, 1909 & 9.0 & .... do. . & 6.2 & 39.7 & 6.1 & 298 & 74 & 372 \\
\hline 469 & .... do ........ & 9.5 & .....do. & 2.5 & 18.3 & 7.5 & 135 & 91 & 226 \\
\hline 66 & Aug. 13, 1909 & 13. 0 & Very scattering... & 4.0 & 6.8 & 3.6 & 70 & 44 & 114 \\
\hline 73 & ..... do...... & 8.5 & Depleted............ & 2.6 & 6.9 & 2.0 & 62 & 24 & 86 \\
\hline 84 & ............ & 10.0 & ....do............. & .0 & 1.3 & .7 & 8 & 8 & 16 \\
\hline 99 & Aug. 14,1909 & 9.0 & ..... do. & .3 & 7.3 & 2.4 & 49 & 29 & 78 \\
\hline 100 & ................. & 8.0 & ....do.. & .3 & .3 & 1.2 & 4 & 14 & 18 \\
\hline
\end{tabular}

\section{ROCKS BETWEEN FISHING POINT AND BALLARDS MARSH ROCKS.}

In this region there are two small rocks for which no names were obtained. One of these lies close to the Baylor line and is encroached on by planted areas. It consists of a dense area inshore, the oysters becoming very scattering farther out, surrounded by a fringe of depleted bottom. The other bed is a small patch of very scattering growth about 400 yards farther out, in the direction of Dog Shoal Rock.

The following table exhibits the extent and condition of these beds:

Oyster Growth on Rocks Between Fishing Point and Ballards Marsh Rocks.

\begin{tabular}{|c|c|c|c|c|}
\hline \multirow{2}{*}{ Character of growth of market oysters. } & \multirow{2}{*}{ Area. } & \multicolumn{2}{|c|}{ Oysters per acre. } & \multirow{2}{*}{$\begin{array}{l}\text { Estimated } \\
\text { content } \\
\text { of market } \\
\text { oysters. }\end{array}$} \\
\hline & & Seed. & Market. & \\
\hline $\begin{array}{l}\text { Dense } \\
\text { Very scattering. } \\
\text { Depleted.......... }\end{array}$ & $\begin{array}{r}\text { Acres. } \\
5 \\
8 \\
18\end{array}$ & $\begin{array}{r}\text { Bushels. } \\
183 \\
1 \\
0\end{array}$ & $\begin{array}{r}\text { Bushels. } \\
268 \\
31 \\
0\end{array}$ & $\begin{array}{r}\text { Bushels. } \\
1,340 \\
248 \\
0\end{array}$ \\
\hline Total.... & 31 & ........... & $\ldots \ldots \ldots$ & 1,588 \\
\hline
\end{tabular}


The dense area varies considerably in productiveness, one spot near what appeared to be the center of the original bed producing a quantity of oysters sufficient to yield 50 bushels per day to the tonger, while in another place not more than 9 bushels coula be taken.

On the very scattering area of the larger bed barely 3 bushels per day could be taken, but on the small isolated spot the growth was sufficient to yield about 4 bushels per day. The depleted area is practically bare of oysters of all sizes, and the quantity of shells is negligible. On the small strip in the dense bottom where the market oysters were most abundant there is a very dense growth of young, but the rest of the bed is deficient in this respect.

The following table gives the results of the several examinations of the beds:

Details of Examination of Beds Between Fishing Point and Ballards Marsh Rocks.

\begin{tabular}{|c|c|c|c|c|c|c|c|c|c|}
\hline \multirow{2}{*}{$\begin{array}{c}\text { Station } \\
\text { num- } \\
\text { ber. }\end{array}$} & \multirow{2}{*}{$\begin{array}{l}\text { Date of ex- } \\
\text { amination. }\end{array}$} & \multirow{2}{*}{$\begin{array}{l}\text { Mean } \\
\text { depth } \\
\text { of wa- } \\
\text { ter. }\end{array}$} & \multirow{2}{*}{$\begin{array}{l}\text { Character of growth } \\
\text { of market oysters. }\end{array}$} & \multicolumn{3}{|c|}{$\begin{array}{l}\text { Oyssters caught per } \\
\text { square yard. }\end{array}$} & \multicolumn{3}{|c|}{$\begin{array}{c}\text { Estimated quantity oys- } \\
\text { ters per acre. }\end{array}$} \\
\hline & & & & Spat. & Culls. & Counts. & Seed. & Market. & Total. \\
\hline $\begin{array}{r}93 \\
95 \\
98 \\
464 \\
96 \\
97 \\
463\end{array}$ & $\begin{array}{l}\text { Aug. } 14,1909 \\
\ldots \ldots \text { do } \ldots . . . . \\
\text { Sept. } 3,1909 \\
\text { Aug. } 14,1909 \\
\text { Sept. } 3,1909\end{array}$ & $\begin{array}{r}\text { Feet. } \\
7.5 \\
7.5 \\
7.0 \\
8.5 \\
8.5 \\
8.5 \\
8.5\end{array}$ & 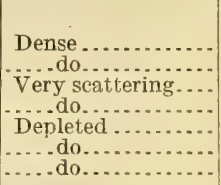 & $\begin{array}{l}0.0 \\
.0 \\
.3 \\
.0 \\
.0 \\
.0 \\
.0\end{array}$ & $\begin{array}{r}0.0 \\
56.4 \\
.0 \\
.0 \\
.0 \\
.0 \\
.0\end{array}$ & $\begin{array}{r}7.0 \\
37.3 \\
3.1 \\
2.0 \\
.0 \\
.0 \\
.0\end{array}$ & $\begin{array}{r}\text { Bush. } \\
0 \\
366 \\
2 \\
0 \\
0 \\
0 \\
0\end{array}$ & $\begin{array}{r}\text { Bush. } \\
85 \\
451 \\
37 \\
25 \\
0 \\
0 \\
0\end{array}$ & $\begin{array}{r}\text { Bush. } \\
85 \\
817 \\
39 \\
25 \\
0 \\
0 \\
0\end{array}$ \\
\hline
\end{tabular}

BALLARDS MARSH ROCK.

This is the bed called by Winslow "Bally Smash," probably an unconscious attempt to render a provincial pronunciation phonetically. It is the westernmost bed of Public Ground No. 6, Isle of Wight County. It follows the line of a shoal which sets offshore from Ballards Marsh.

Its extent and condition are epitomized in the following table:

Oyster Growth on Ballards Marsh Rock.

\begin{tabular}{|c|c|c|c|c|}
\hline \multirow{2}{*}{ Character of growth of market oysters. } & \multirow{2}{*}{ Area. } & \multicolumn{2}{|c|}{ Oysters per acre. } & \multirow{2}{*}{$\begin{array}{l}\text { Estimated } \\
\text { content of } \\
\text { maiket } \\
\text { oysters. }\end{array}$} \\
\hline & & Seed. & Market. & \\
\hline $\begin{array}{l}\text { Scattering. } \\
\text { Very scattering } \\
\text { Depleted. }\end{array}$ & $\begin{array}{r}\text { Acres. } \\
4 \\
33 \\
142\end{array}$ & $\begin{array}{r}\text { Bushels. } \\
152 \\
191 \\
45\end{array}$ & $\begin{array}{r}\text { Bushels. } \\
31 \\
24 \\
7\end{array}$ & $\begin{array}{r}\text { Bushels. } \\
124 \\
792 \\
894\end{array}$ \\
\hline Total. & 179 & & & 1,810 \\
\hline
\end{tabular}


The scattering area is a small spot near the inner end of the shoal, where the quantity of market oysters is sufficient to yield to the tonger between 7 and 8 bushels per day. The very scattering growth is found on each side of this and beyond it for a distance of about two-thirds the length of the shoal, bearing a growth yielding about $3 \frac{1}{2}$ bushels of oysters per day's work. On both sides of the very scattering area and beyond it along the line of the shoal is a depleted bottom on which, as a whole, less than 1 bushel of oysters can be taken per day, the edges of the area being practically barren.

Along both sides of the shoal, even on the so-called depleted bottom which surrounds it at its outer end, is a heavy growth of young and many shells, which will yield on the average about 35 bushels of culls and spat per day. The market oysters on this bed will average about 400 to the bushel and the culls or seed oysters about 750 .

Details of Examination of Ballards Marsh Rock.

\begin{tabular}{|c|c|c|c|c|c|c|c|c|c|}
\hline \multirow{2}{*}{$\begin{array}{c}\text { Station } \\
\text { num- } \\
\text { ber. }\end{array}$} & \multirow{2}{*}{$\begin{array}{l}\text { Date of ex- } \\
\text { amination. }\end{array}$} & \multirow{2}{*}{$\begin{array}{c}\text { Mean } \\
\text { depth } \\
\text { of wa- } \\
\text { ter. }\end{array}$} & \multirow{2}{*}{$\begin{array}{l}\text { Character of growth } \\
\text { of market oysters. }\end{array}$} & \multicolumn{3}{|c|}{$\begin{array}{l}\text { Oysters caught per } \\
\text { square yard. }\end{array}$} & \multicolumn{3}{|c|}{$\begin{array}{c}\text { Estimated quantity oys- } \\
\text { ters per acre. }\end{array}$} \\
\hline & & & & Spat. & Culls. & Counts. & Seed. & Market. & Total. \\
\hline & Aug. 14,1909 & $\begin{array}{l}\text { Feet. } \\
3.0\end{array}$ & Scattering & & & & Bush. & Bush. & Bush. \\
\hline 85 & do........ do & $\begin{array}{l}\text { 5. } \\
6.0\end{array}$ & Very scattering .... & $\begin{array}{r}15.6 \\
3.2\end{array}$ & $\begin{array}{l}9.1 \\
3.2\end{array}$ & $\begin{array}{l}2.0 \\
2.1\end{array}$ & $\begin{array}{r}152 \\
42\end{array}$ & $\begin{array}{l}31 \\
25\end{array}$ & $\begin{array}{r}18 \\
67\end{array}$ \\
\hline 462 & Sept. 3,1909 & 5.0 & .... do do.................. & 6.6 & 21.7 & 2.0 & 184 & 25 & 209 \\
\hline 514 & Sept. 9,1909 & 4.0 & ....do.... & 10.8 & 42.3 & 1.8 & 346 & 22 & 368 \\
\hline 87 & Aug. 14, 1909 & 6.0 & Depleted & .3 & 2.3 & 1.4 & 17 & 17 & 34 \\
\hline 88 & $\ldots$ do..... & 7.0 & ...... do... & .0 & .0 & .0 & 0 & 0 & 0 \\
\hline 89 & .... do......... & 9.0 & do. & .0 & .0 & 1.7 & 0 & 21 & 21 \\
\hline 90 & .....do... & 7.0 & .....do.. & .0 & .0 & .0 & 0 & 0 & 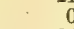 \\
\hline 91 & …do.. & 7.0 & $\ldots . . d$ & .0 & .3 & 1.8 & 2 & 22 & 24 \\
\hline 461 & Sept. 3,1909 & 7.0 & …..d d & 4.7 & 27.7 & 1.3 & 211 & 16 & 227 \\
\hline 504 & Sept. 9,1909 & 6.0 & ..... do..... & .0 & .0 & .0 & 0 & 0 & 0 \\
\hline 505 & ..... do ........ & 5.0 & ...... do ...... & 5.7 & 22.5 & .4 & 183 & 5 & 188 \\
\hline & ..... do . . & 4.5 & .....do... & 7.4 & 21.0 & .5 & 185 & 6 & 191 \\
\hline & .d & 4. & $\ldots . . d$ & 10.3 & 22.4 & .2 & 213 & 2 & 215 \\
\hline 5 & $d$ & 6. & ....do & .0 & .0 & .2 & 0 & 2 & 2 \\
\hline 5 & 6 & 5. & $\ldots . . \mathrm{dc}$ & .0 & .0 & .9 & 0 & 11 & 11 \\
\hline 5 & d & 6. & $\ldots . . . \mathrm{do}$ & .0 & .0 & .7 & 0 & 8 & 8 \\
\hline & 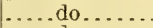 & 6. & $\ldots$. & .0 & .0 & .2 & 0 & 2 & 2 \\
\hline 518 & . d & 7.0 & .... do & .0 & .0 & .5 & 0 & 6 & 6 \\
\hline 519 & d & 7.0 & .....d & .0 & .3 & 1.4 & 2 & 17 & 19 \\
\hline 520 & 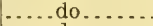 & 6. & $\ldots . . d$ & .0 & .0 & .0 & 0 & 0 & 0 \\
\hline 521 & 4 & 5.5 & .... do. & .0 & .0 & .0 & 0 & 0 & \\
\hline
\end{tabular}

\section{CREEK CHANNEL ROCK.}

This is a small bed about 2 acres in extent, covering a shoal marked by a buoy of the Light-House Establishment. It has the indications of having been a dense bed, but at the present time it is depleted, and a tonger could take on it an average of hardly a bushel of oysters per day, and the young growth is still more sparse. It is surrounded by private beds. It constitutes Public Ground No. 5, Isle of Wight County. 
The following observations were made on this bed:

Detalls of Examination of Creek Channel Shoal Rock.

\begin{tabular}{|c|c|c|c|c|c|c|c|c|c|}
\hline \multirow{2}{*}{$\begin{array}{c}\text { Station } \\
\text { num- } \\
\text { ber. }\end{array}$} & \multirow{2}{*}{$\begin{array}{l}\text { Date of ex- } \\
\text { amination. }\end{array}$} & \multirow{2}{*}{$\begin{array}{l}\text { Mean } \\
\text { depth } \\
\text { of wa- } \\
\text { ter. }\end{array}$} & \multirow{2}{*}{$\begin{array}{l}\text { Character of growth } \\
\text { of market oysters. }\end{array}$} & \multicolumn{3}{|c|}{$\begin{array}{l}\text { Oysters caught per } \\
\text { square yard. }\end{array}$} & \multicolumn{3}{|c|}{$\begin{array}{l}\text { Estimated quantity oys- } \\
\text { ters per acre. }\end{array}$} \\
\hline & & & & Spat. & Culls. & Counts. & Seed. & Market. & Total. \\
\hline $\begin{array}{l}383 \\
384\end{array}$ & $\begin{array}{l}\text { Aug. } 26,1909 \\
\ldots\end{array}$ & $\begin{array}{r}\text { Feet. } \\
13.0 \\
6.0\end{array}$ & $\begin{array}{l}\text { Depleted. } \\
\text {.... do .... }\end{array}$ & $\begin{array}{l}0.0 \\
0.0\end{array}$ & $\begin{array}{l}0.0 \\
1.1\end{array}$ & $\begin{array}{r}1.4 \\
.2\end{array}$ & $\begin{array}{r}\text { Bushels. } \\
0 \\
7\end{array}$ & $\begin{array}{r}\text { Bushels. } \\
19 \\
3\end{array}$ & $\begin{array}{r}\text { Buskels. } \\
19 \\
10\end{array}$ \\
\hline
\end{tabular}

AARON SHOAL ROCK.

This is the only bed in Public Ground No. 2, Isle of Wight County. It is almost or quite surrounded by private beds, the boundary stakes of which formed a forest which made it difficult to tell, without spending on the bed more time than its importance warranted, what was planted ground and what was not.

The following statistics exhibit its present condition:

Oyster Growth on Aaron Shoal Rock.

\begin{tabular}{|c|c|c|c|c|}
\hline \multirow{2}{*}{ Character of growth of market oysters. } & \multirow{2}{*}{$\begin{array}{c}\text { Area. } \\
\text {. }\end{array}$} & \multicolumn{2}{|c|}{ Oysters per acre. } & \multirow{2}{*}{$\begin{array}{l}\text { Estimated } \\
\text { content of } \\
\text { market } \\
\text { oysters. }\end{array}$} \\
\hline & & Seed. & Market. & \\
\hline 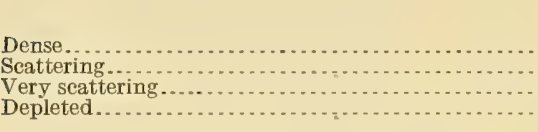 & $\begin{array}{c}\text { Acres. } \\
2 ? \\
4 \\
3 \\
24\end{array}$ & $\begin{array}{r}\text { Bushels. } \\
129 \\
135 \\
0 \\
112\end{array}$ & $\begin{array}{r}\text { Bushels. } \\
100 \\
33 \\
23 \\
5\end{array}$ & $\begin{array}{r}\text { Bushels. } \\
200 \\
132 \\
69 \\
120\end{array}$ \\
\hline Total. . & 31 & & & 521 \\
\hline
\end{tabular}

The dense area forms a very narrow strip along the northern edge close to and among the stakes. Its area could not be very definitely determined without wasteful expenditure of time, but is probably about 2 acres. About 10 bushels of oysters per day could be taken by the tonger.

On the scattering growth it is estimated that about $4 \frac{1}{2}$ bushels, and on the very scattering about 3 bushels, per day could be taken. The depleted area is for the most part bare. There is a good growth of young on the dense and scattered areas and at two spots on the depleted bottom.

The following examinations were made. 
Details of Examination of Aaron Shoal Rock

\begin{tabular}{|c|c|c|c|c|c|c|c|c|c|}
\hline \multirow{2}{*}{$\begin{array}{l}\text { Station } \\
\text { num- } \\
\text { ber. }\end{array}$} & \multirow{2}{*}{$\begin{array}{l}\text { Date of ex- } \\
\text { amination. }\end{array}$} & \multirow{2}{*}{$\begin{array}{l}\text { Mean } \\
\text { depth } \\
\text { of wa- } \\
\text { ter. }\end{array}$} & \multirow{2}{*}{$\begin{array}{l}\text { Character of growth } \\
\text { of market oysters. }\end{array}$} & \multicolumn{3}{|c|}{$\begin{array}{l}\text { Oysters caught per } \\
\text { square yard. }\end{array}$} & \multicolumn{3}{|c|}{$\begin{array}{l}\text { Estimated quantity oys- } \\
\text { ters per acre. }\end{array}$} \\
\hline & & & & Spat. & Culls. & Counts. & Seed. & Market. & Total. \\
\hline $\begin{array}{l}392 \\
396 \\
389 \\
400 \\
390 \\
391 \\
394 \\
395\end{array}$ & 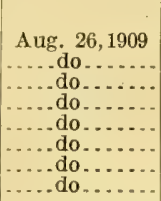 & $\begin{array}{r}\text { Feet. } \\
8.5 \\
5.5 \\
5.5 \\
6.0 \\
5.0 \\
8.5 \\
7.5 \\
6.5\end{array}$ & 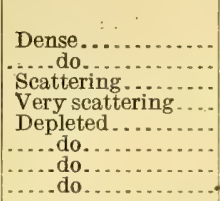 & $\begin{array}{l}0.0 \\
5.7 \\
1.6 \\
.0 \\
6.7 \\
5.0 \\
.0 \\
5.3\end{array}$ & $\begin{array}{r}6.0 \\
28.0 \\
19.2 \\
.0 \\
24.2 \\
10.3 \\
.0 \\
18.7\end{array}$ & $\begin{array}{r}9.7 \\
4.7 \\
2.4 \\
1.7 \\
1.3 \\
.3 \\
.0 \\
.0\end{array}$ & $\begin{array}{r}\text { Bush. } \\
39 \\
219 \\
135 \\
0 \\
201 \\
90 \\
0 \\
156\end{array}$ & $\begin{array}{r}\text { Bush. } \\
134 \\
65 \\
33 \\
23 \\
18 \\
4 \\
0 \\
0\end{array}$ & $\begin{array}{r}\text { Bush. } \\
173 \\
284 \\
168 \\
23 \\
219 \\
94 \\
0 \\
156\end{array}$ \\
\hline
\end{tabular}

BROWNS SHOAL ROCKS.

Included under this name are a number of small rocks, separated by depleted and barren bottom lying at the extreme lower end of public ground No. 1, Warwick County, just above Newport News. The productive portions lie on Browns Shoal and a number of other shoal spots in the vicinity. The extent and present condition of the rocks as a whole are shown in the following table:

Oyster Growth on Browns Shoal Rocks.

\begin{tabular}{|c|c|c|c|c|}
\hline \multirow{2}{*}{ Character of growth of market oysters. } & \multirow{2}{*}{ Area. } & \multicolumn{2}{|c|}{ Oysters per acre. } & \multirow{2}{*}{$\begin{array}{l}\text { Estimated } \\
\text { content of } \\
\text { market } \\
\text { oysters. }\end{array}$} \\
\hline & & Seed. & Market. & \\
\hline $\begin{array}{l}\text { Dense. } \\
\text { Seattering } \\
\text { Very seattering } \\
\text { Depleted. }\end{array}$ & $\begin{array}{r}\text { Acres. } \\
68 \\
44 \\
27 \\
226\end{array}$ & $\begin{array}{r}\text { Bushels. } \\
126 \\
142 \\
88 \\
5\end{array}$ & $\begin{array}{r}\text { Bushels, } \\
183 \\
54 \\
39 \\
4\end{array}$ & $\begin{array}{r}\text { Bushels. } \\
12,444 \\
2,376 \\
1,053 \\
904\end{array}$ \\
\hline Total. . & 365 & & & 16,777 \\
\hline
\end{tabular}

The dense area is found in seven patches, of which the largest, covering about 25 acres, is on a shoal west of Browns Shoal surrounding a watchhouse or covered pierhead. The areas as a whole are quite productive of market oysters, and it is estimated that an industrious tonger working nine hours per day could take between 10 and 40 bushels of oysters, the average at all places examined being about 15 bushels.

The areas of scattering growth are three in number, lying on tne ends of Browns Shoal proper and a small shoal west of it, inshore of the watchhouse above alluded to. They carry a depth of between about 4 or 5 and 12 feet at low water, and their productiveness is such that a tonger could take an average of between 5 and 6 bushels of market oysters per day.

The areas of very scattering growth are a number of small patches nearly all lying between the more prolific areas and the edges of the bed. They are nearly all covered by about 10 feet of water at low tide, and bear oysters in sufficient quantity to yield to the tonger between 3 and 4 bushels per day. 
The depleted bottom constitutes nearly two-thirds of the total area of the beds as charted. At no place does it promise to yield during the present season more than $2 \frac{1}{2}$ bushels per day, and the major part of it is practically barren.

The growth of young oysters is very good on the shallower parts of the beds, especially on those portions yielding a scattering growth of market stock, where a tonger could take an average of about 15 bushels per day. On the dense areas as a whole the young growth is less abundant, the estimated average yield being about 11 bushels per day, the heaviest growth being on two small shoals between the inner end of Browns Shoal and the shipyard at Newport News.

On all of the productive areas there is an abundance of shells suitable for catching a set of 'spat, but the depleted areas are practically bare and give no promise of recuperation under any natural conditions.

The following exhibits the results of examinations:

Detalls of Examination of Browns Shoal Rocks.

\begin{tabular}{|c|c|c|c|c|c|c|c|c|c|}
\hline \multirow{2}{*}{$\begin{array}{c}\text { Station } \\
\text { num- } \\
\text { ber. }\end{array}$} & \multirow{2}{*}{$\begin{array}{c}\text { Date of exami- } \\
\text { nation. }\end{array}$} & \multirow{2}{*}{$\begin{array}{l}\text { Mean } \\
\text { depth } \\
\text { of } \\
\text { water. }\end{array}$} & \multirow{2}{*}{$\begin{array}{l}\text { Character of growth } \\
\text { of market oysters. }\end{array}$} & \multicolumn{3}{|c|}{$\begin{array}{l}\text { Oysters caught per } \\
\text { square yard. }\end{array}$} & \multicolumn{3}{|c|}{$\begin{array}{c}\text { Estimated quantity oys- } \\
\text { ters per acre. }\end{array}$} \\
\hline & & & & Spat. & Culls. & Counts. & Seed. & Market. & Total. \\
\hline & & Feet. & & & & & Bush. & Bush. & Bush. \\
\hline $112^{\circ}$ & Aug. 16, 1909 & 9.5 & Dense.. & 4.7 & 31.9 & 12.0 & 238 & 165 & 403 \\
\hline 122 & .... do....... & 9.5 & ..... do. . & .0 & 24.6 & 7.9 & 160 & 109 & 269 \\
\hline 123 & ... do ... & 8.5 & .... do.............. & 1.3 & 21.6 & 9.6 & 149 & 133 & 282 \\
\hline 126 & ..... do... & 8.0 & .... do............. & .0 & 10.7 & 7.3 & 70 & 101 & 171 \\
\hline 139 & Aug. 17, 1909 & 9.5 & do.. & 1.6 & 6.4 & 32.0 & 52 & 443 & 495 \\
\hline 141 & .... do....... & 11.5 & .. do. . & 2.0 & $11 . \overline{2}$ & 9.6 & 86 & 133 & 219 \\
\hline 142 & ... do... & 14.5 & ... do $\ldots$........ & 7.2 & 15.6 & 12.8 & 148 & 177 & 325 \\
\hline 144 & do.. & 10.5 & . do............ & 1.5 & 18.0 & 10.5 & 127 & 145 & 272 \\
\hline 145 & do. & 12.5 & .. do. . & 1.5 & 11.0 & 14.5 & 81 & 200 & 281 \\
\hline 146 & ..... do. & 13.5 & do. & .0 & 9.2 & 24.4 & 60 & 337 & 397 \\
\hline 450 & Sept. 1, 1909 & 10.0 & do. & 5.2 & 37.8 & 4.4 & 280 & 61 & 341 \\
\hline 459 & Sept. 3,1909 & 10.5 & . do........ & 5.0 & 21.2 & 10.8 & 170 & 149 & 319 \\
\hline 460 & ..... do... & 10.5 & do........... & 2.1 & 16.2 & 20.8 & 119 & 287 & 406 \\
\hline 524 & Sept. 10, 1909 & 11.5 & do & .0 & 4.0 & 9.0 & 26 & 124 & 150 \\
\hline 115 & Aug. 16,1909 & 9.0 & Scattering. . & .3 & 28.7 & 6.3 & 188 & 87 & 275 \\
\hline 118 & ... do...... & 7.0 & ... do........ & .6 & 21.2 & 4.0 & 141 & 55 & 196 \\
\hline 119 & .... do. . & 6.0 & .... do . . . . . & .9 & 12. & 2. & 89 & 32 & 121 \\
\hline 120 & ...do... & 6.0 & ... do ............. & 4.5 & 11. & 2.5 & 100 & 34 & 134 \\
\hline 136 & Aug. 17, 1909 & 10.0 & ... do . . . . . & 3.6 & 25.6 & 4.4 & 190 & 61 & 251 \\
\hline 138 & ... do...... & 9.0 & ... do... & 2.0 & 31.0 & 4.0 & 214 & 55 & 269 \\
\hline 143 & .....do... & 12.5 & ... do.. & 0 & 2.8 & 6.4 & 18 & 88 & 106 \\
\hline 451 & Sept. 1, 1909 & 7.5 & .... do... & 12.3 & 34. & 3.0 & 301 & 41 & 342 \\
\hline 452 & .... do....... & 11.0 & .... do.......... & 7.3 & 20. & 5. & 180 & 80 & 260 \\
\hline 453 & .... do ... & 10.0 & do............ & 2.9 & 12.1 & 4.6 & 98 & 64 & 162 \\
\hline 117 & Aug. 16,1909 & 5.0 & Very scattering. & .2 & 12.9 & 2.2 & 85 & 30 & 115 \\
\hline 125 & $\ldots$ do... & 10.0 & . . do.............. & .3 & 3.7 & 3.3 & 26 & 45 & 71 \\
\hline 135 & Aug. 17,1909 & 11.0 & .... do... & 2.0 & 6. & 3. & 52 & 44 & 96 \\
\hline 140 & ... do....... & 11.0 & do & 0 & 8. & 2 . & 57 & 39 & 96 \\
\hline 457 & Sept. 3, 1909 & 11.0 & . do.... & 8.2 & 26.2 & 2.5 & 223 & 35 & 258 \\
\hline 458 & .... do... & 10.5 & ..do. & 2.9 & 9.6 & 3.8 & 81 & 52 & 133 \\
\hline 523 & Sept. 10,1 & 10.0 & ... do. & 2.0 & 12.5 & 2.0 & 94 & 28 & 122 \\
\hline 113 & Aug. 16,1909 & 12.6 & Depleted. & .0 & 5.7 & 2.0 & 37 & 28 & 65 \\
\hline 114 & .... do....... & 10.5 & .... do.... & .0 & .0 & .0 & 0 & 0 & 0 \\
\hline 116 & . do... & 12.0 & ....do.. & .0 & .3 & .0 & 2 & 0 & 2 \\
\hline 124 & .. do.. & 12.0 & ...do.. & .0 & .0 & .0 & 0 & 0 & 0 \\
\hline 137 & Aug. 17, 1909 & 12.0 & .... do... & .0 & .0 & .0 & 0 & 0 & 0 \\
\hline 449 & Sept. 1,1909 & 18.0 & .... do... & .0 & .0 & .0 & 0 & 0 & 0 \\
\hline 454 & ... do...... & 18.0 & do. & .0 & 2.3 & 1.4 & 15 & 19 & 34 \\
\hline 455 & . do.. & 10.5 & ... do.. & .0 & .0 & .0 & 0 & 0 & 0 \\
\hline 456 & .. do.. & 11.0 & ... do. & .0 & .0 & .0 & 0 & & 0 \\
\hline 522 & Sept. 10,1909 & 24.0 & .... do.. & .0 & .0 & .0 & 0 & 0 & 0 \\
\hline 567 & Sept. 14, 1909 & 20.5 & ... do... & .0 & .0 & .0 & 0 & 0 & 0 \\
\hline
\end{tabular}


GUN ROCK.

This is a small bed lying on a shoal spot west of the preceding. Its extent and estimated density of growth and contents are as follows:

Oyster Growth on Gun Rock.

\begin{tabular}{|c|c|c|c|c|}
\hline \multirow{2}{*}{ Character of growth of market oysters. } & \multirow{2}{*}{ Area. } & \multicolumn{2}{|c|}{ Oysters per acre. } & \multirow{2}{*}{$\begin{array}{l}\text { Estimated } \\
\text { content of } \\
\text { market } \\
\text { oysters. }\end{array}$} \\
\hline & & Seed. & Market. & \\
\hline 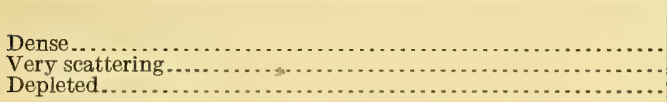 & $\begin{array}{r}\text { Acres. } \\
6 \\
16 \\
4\end{array}$ & $\begin{array}{r}\text { Bushels. } \\
198 \\
62 \\
0\end{array}$ & $\begin{array}{r}\text { Bushels. } \\
152 \\
30 \\
0\end{array}$ & $\begin{array}{r}\text { Bushels. } \\
912 \\
480 \\
0\end{array}$ \\
\hline Total.. & 26 & & $\ldots$ & 1,392 \\
\hline
\end{tabular}

The dense area forms a narrow tongue running along the inner or shoreward end of the ridge or backbone of the shoal, and it produces market oysters in sufficient quantity to yield the tonger about 9 bushels per day. There is no scattering growth, but the outer half of the length of the bed as far as the Baylor line produces a very scattering growth sufficient to yield about 3 bushels per day.

Along the higher parts of the ridge, on both the dense and very scattering bottoms, there is a prolific growth of young oysters, sufficient to furnish the tonger from 12 to 14 bushels per day. The edges of the very scattering area produce but few young oysters, and the depleted bottom is practically bare of both oysters and clean shells, its position being indicated solely by the presence of shells more or less deeply buried in the mud.

The following observations were made:

Details of Examination of Gun Rock.

\begin{tabular}{|c|c|c|c|c|c|c|c|c|c|}
\hline \multirow{2}{*}{$\begin{array}{c}\text { Station } \\
\text { num- } \\
\text { ber. }\end{array}$} & \multirow{2}{*}{$\begin{array}{l}\text { Date of ex- } \\
\text { amination. }\end{array}$} & \multirow{2}{*}{$\begin{array}{c}\text { Mean } \\
\text { depth } \\
\text { of wa- } \\
\text { ter. }\end{array}$} & \multirow{2}{*}{$\begin{array}{l}\text { Character of growth } \\
\text { of market oysters. }\end{array}$} & \multicolumn{3}{|c|}{$\begin{array}{l}\text { Oysters caught per } \\
\text { square yard. }\end{array}$} & \multicolumn{3}{|c|}{$\begin{array}{l}\text { Estimated quantity oys- } \\
\text { ters per acre. }\end{array}$} \\
\hline & & & & Spat. & Culls. & Counts. & Seed. & Market. & Total. \\
\hline $\begin{array}{l}134 \\
147 \\
149 \\
148\end{array}$ & 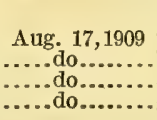 & $\begin{array}{r}\text { Feet. } \\
16.0 \\
6.5 \\
12.5 \\
12.5\end{array}$ & $\begin{array}{l}\text { Dense.............. } \\
\text { Very scattering..... } \\
\text { Depleted................ }\end{array}$ & $\begin{array}{l}2.0 \\
.8 \\
.0 \\
.0\end{array}$ & $\begin{array}{r}28.5 \\
17.4 \\
1.0 \\
.0\end{array}$ & $\begin{array}{r}11.0 \\
1.8 \\
2.5 \\
.0\end{array}$ & $\begin{array}{r}\text { Bush. } \\
198 \\
118 \\
6 \\
0\end{array}$ & $\begin{array}{r}\text { Bush. } \\
152 \\
25 \\
34 \\
0\end{array}$ & $\begin{array}{r}\text { Bush. } \\
350 \\
143 \\
40 \\
0\end{array}$ \\
\hline
\end{tabular}

KETTLE HOLE ROCK.

I am not certain of the name of this bed, as in the field some confusion arose as to whether this or the next was Thomas Point Rock. In designating it as above I have been guided by Winslow's nomenclature. This bed is the largest and most important in this part of 
the river. It lies on the north side of a shallow ridge, extending thence shoreward toward Watts Creek as far as the Baylor line.

Its extent and present general condition are as follows:

Oyster Growth on Ketrle Hole Rock.

\begin{tabular}{|c|c|c|c|c|}
\hline \multirow{2}{*}{ Character of growth of market oysters. } & \multirow{2}{*}{ Area. } & \multicolumn{2}{|c|}{ Oysters per acre. } & \multirow{2}{*}{$\begin{array}{l}\text { Estimated } \\
\text { content of } \\
\text { market } \\
\text { oysters. }\end{array}$} \\
\hline & & Seed. & Market. & \\
\hline 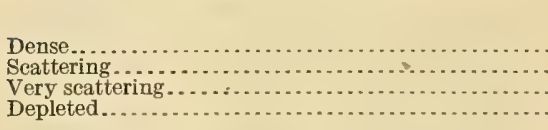 & $\begin{array}{r}\text { Acres. } \\
258 \\
66 \\
111 \\
11\end{array}$ & \begin{tabular}{|r|} 
Bushels. \\
317 \\
207 \\
180 \\
0
\end{tabular} & \begin{tabular}{|r|} 
Bushels. \\
105 \\
82 \\
42 \\
0
\end{tabular} & $\begin{array}{r}\text { Bushels. } \\
27,090 \\
5,412 \\
4,662 \\
0\end{array}$ \\
\hline Total.... & 446 & .... & $\ldots$ & 37,164 \\
\hline
\end{tabular}

The principal area of dense growth starts from the ridge and extends as a broad belt as far as the Baylor line inshore. The public ground includes but a portion of the shoal, possibly because the southern part was taken up as private ground prior to the Baylor survey. The productive bottom probably extends across the ridge, but as it is not included in the public grounds and is staked as a private holding it was not examined. The growth of market oysters on the public ground is rather uniform and is sufficient to provide the tonger with from 8 to 13 bushels per day, the average being about 9 or 10 . Near the middle of the inner part of the dense area is a smal spot where market oysters are deficient in quantity, but the growth of young is so prolific that it has not been thought advisable to differentiate it on the chart. There is also a small area of dense growth on a shallow spot east of the main area.

The scattering growth on Kettle Hole Rock forms a fringe along the western border of the dense area, with a broad tongue thrust into the latter near its middle. The growth of market oysters is sufficient to yield to the tonger an average of about 6 bushels per day.

The areas of very scattering growth form a border on the eastern and inshore edges of the dense growth, and it is estimated that about 3 or $3 \frac{1}{2}$ bushels of oysters could be tonged per day on the areas taken in their entirety.

The depleted bottom is insignificant and bare of everything except a few buried shells.

There is a heavy growth of young oysters over practically the entire extent of this bed. On the dense areas they are estimated to be present in sufficient quantities to yield to the tonger about 28 bushels per day as an average at the beginning of the season, while on the scattering and very scattering areas the yield would probably average about 16 or 17 bushels. Undoubtedly the entire bed can be regarded as 
presently and prospectively productive. The following data were obtained from the examinations made:

Details of Examination of Kettle Hole Rock.

\begin{tabular}{|c|c|c|c|c|c|c|c|c|c|}
\hline \multirow{2}{*}{$\begin{array}{c}\text { Station } \\
\text { num- } \\
\text { ber. }\end{array}$} & \multirow{2}{*}{$\begin{array}{l}\text { Date of ex- } \\
\text { amination. }\end{array}$} & \multirow{2}{*}{$\begin{array}{c}\text { Mean } \\
\text { depth } \\
\text { of wa- } \\
\text { ter. }\end{array}$} & \multirow{2}{*}{$\begin{array}{l}\text { Character of growth } \\
\text { of market oysters. }\end{array}$} & \multicolumn{3}{|c|}{$\begin{array}{l}\text { Oysters eaught per } \\
\text { square yard. }\end{array}$} & \multicolumn{3}{|c|}{$\begin{array}{c}\text { Estimated quantity oys- } \\
\text { ters per acre. }\end{array}$} \\
\hline & & & & Spat. & Culls. & Counts. & Seed. & Market. & Total. \\
\hline & & Feet. & & & & & Bush. & Bush. & Bush. \\
\hline 133 & Aug. 17, 1909 & 10.0 & Dense.......... & 8.5 & & 10.0 & 364 & 138 & 502 \\
\hline 155 & .......... do & $\begin{array}{l}13.5 \\
11.5\end{array}$ & & $\begin{array}{l}5.0 \\
1.5\end{array}$ & $\begin{array}{l}62.0 \\
29.9\end{array}$ & 7. & 436 & 104 & $\begin{array}{l}540 \\
312\end{array}$ \\
\hline 157 & do.. & 11.5 & do.. & .0 & 32.0 & 8.0 & 208 & 111 & $\begin{array}{l}512 \\
319\end{array}$ \\
\hline 159 & ... do .... & 9.5 & . do... & 0 & 44. 6 & .7 & 290 & 10 & 300 \\
\hline 360 & Aug. 26, 1909 & $\cdot 11.5$ & ..do...... & 5.0 & 27.5 & 11.7 & 211 & 161 & 372 \\
\hline 361 & ... do........ & 11.5 & do... & 2.1 & 18.5 & 7.6 & 134 & 105 & 239 \\
\hline 362 & .... do... & 10.5 & do... & 8.1 & 54.6 . & 9. & 408 & 133 & 541 \\
\hline & ....do... & 8 & . do.... & 6.5 & 47. & 6. & 349 & 84 & 433 \\
\hline & .... do....... & 7. & . do..... & 7.6 & 46. & 7. & 353 & 109 & 462 \\
\hline & ..... do........ & 8. & do... & 9.6 & 72.4 & 6. & 533 & 90 & 623 \\
\hline 158 & Aug. 17, 1909 & 12.5 & Scattering ..... & 5.0 & 34.6 & 5. & 257 & 76 & 333 \\
\hline 163 & Aug. 18, 1909 & 17.0 & .... do......... & .7 & 50.0 & 6.9 & 334 & 95 & 429 \\
\hline 359 & Aug. 26, 1909 & 11.0 & ..... do.. & .9 & 3.8 & 5.4 & 31 & 75 & 106 \\
\hline 151 & Aug. 17, 1909 & 11.0 & Very scattering.... & .0 & 16. 0 & 4.0 & 104 & 55 & 159 \\
\hline 152 & $\ldots . . . \mathrm{do} . . . .$. & 13.0 & .... do........... & .4 & 43.3 & 2.1 & 284 & 29 & 313 \\
\hline 153 & .....do.. & 11.5 & . do... & 1.1 & 13.3 & 3.0 & 95 & 41 & 136 \\
\hline 154 & .....do. . & 11.5 & ...do.... & .2 & 24.0 & 3.3 & 169 & 46 & 215 \\
\hline 369 & Aug. 26, 1909 & 11.5 & .... do... & 7.9 & 30.0 & 2.9 & 246 & 40 & 286 \\
\hline 164 & Aug. 18, 1909 & 14.0 & Depleted .. & .0 & .0 & .0 & 0 & 0 & 0 \\
\hline 165 & ..... do........ & 16.0 & ..... do... & .0 & .0 & .0 & 0 & 0 & 0 \\
\hline
\end{tabular}

THOMAS POINT ROCK.

As explained in the discussion of the preceding bed, there may be some question as to the name of this one, which lies between what has been called Kettle Hole Rock and Blunt Point Rock. It is entirely separated from the former by a swash channel carrying from 12 to 21 feet of water, but is connected with Blunt Point Rock by a narrow ridge of depleted bottom. The bed lies on and about two shoals which extend from the edge of the channel lying north of White Shoal Light. Its extent and condition are as follows:

Oyster Growth on Thomas Point Rock.

\begin{tabular}{|c|c|c|c|c|}
\hline \multirow{2}{*}{ Character of growth of market oysters. } & \multirow{2}{*}{ Area. } & \multicolumn{2}{|c|}{ Oysters per acre. } & \multirow{2}{*}{$\begin{array}{l}\text { Estimated } \\
\text { content of } \\
\text { market } \\
\text { oysters. }\end{array}$} \\
\hline & & Seed. & Market. & \\
\hline 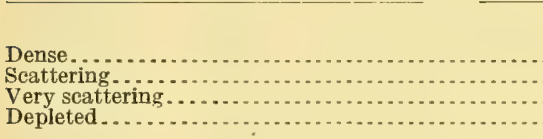 & $\begin{array}{r}\text { Acres. } \\
76 \\
118 \\
100 \\
127\end{array}$ & \begin{tabular}{|r} 
Bushels. \\
168 \\
170 \\
103 \\
80
\end{tabular} & $\begin{array}{r}\text { Bushels. } \\
115 \\
71 \\
51 \\
21\end{array}$ & $\begin{array}{r}\text { Bushels. } \\
8,745 \\
8,378 \\
5,100 \\
2,667\end{array}$ \\
\hline Total.... & 421 & .... & .... & 24.890 \\
\hline
\end{tabular}

The dense growth of market oysters is in three patches, all lying on or close to the shoaler parts of the bed in water ranging from 5 to 8 feet at low tide. The growth is sufficiently prolific to yield to the tonger about 10 bushels of marketable oysters per day. 
The area covered by scattering marketable oysters stretches from the western side of the longer shoal across some intervening deeper water to two small shoals to the westward. Over the whole area the density of growth is such that about 6 bushels of oysters may be taken per day.

The very scattered growth is in three areas fringing the denser parts of the bed. Its productiveness varies between areas which will yield $2 \frac{1}{2}$ and those which will yield $4 \frac{1}{2}$ bushels per day, the general average at all places examined being about $3 \frac{1}{2}$ bushels.

The best of the depleted bottom, which is in the areas lying on the edge of the deep-water channel, will yield about $2 \frac{1}{2}$ bushels per day, while the inshore area and that lying in the midst of the scattering growth will not yield an average of over 1 bushel.

The young growth is in good quantity, though not so abundant as on Kettle Hole Rock. On the dense and scattering areas it is sufficient to yield an average of about 15 bushels per day. On the very scattering area near the inshore end of the eastern edge of the rock it is in about the same abundance, but elsewhere it will yield not more than $4 \frac{1}{2}$ bushels per day's tonging. On the best of the depleted bottom, along the edge of the deep-water channel, it is estimated that about 10 or 11 bushels per day could be taken by the tonger, but on other parts of the depleted area young oysters are practically absent.

The oysters on this bed, as on all others on this shore of the river, are of fair size, the marketable stock averaging about 350 per bushel and the young approximately 750 .

The following observations were made:

Detalls of Examination of Thomas Point Rock.

\begin{tabular}{|c|c|c|c|c|c|c|c|c|c|}
\hline \multirow{2}{*}{$\begin{array}{l}\text { Station } \\
\text { num- } \\
\text { ber }\end{array}$} & \multirow{2}{*}{$\begin{array}{l}\text { Date of ex- } \\
\text { amination. }\end{array}$} & \multirow{2}{*}{$\begin{array}{c}\text { Mean } \\
\text { depth } \\
\text { of wa- } \\
\text { ter. }\end{array}$} & \multirow{2}{*}{$\begin{array}{l}\text { Character of growth } \\
\text { of market oysters. }\end{array}$} & \multicolumn{3}{|c|}{$\begin{array}{l}\text { Oysters caught per } \\
\text { square yard. }\end{array}$} & \multicolumn{3}{|c|}{$\begin{array}{l}\text { Estimated quantity oys- } \\
\text { ters per acre. }\end{array}$} \\
\hline & & & & Spat. & Culls. & Counts. & Seed. & Market. & Total. \\
\hline & Ang 17.1909 & Feet. & Dense. & 0.8 & 2,1 & 11.2 & Bush. & Bush. & Bush. \\
\hline 132 & Aug. 17, 1909 & 12.5 & Deuse. & $\begin{array}{l}0.0 \\
9.6\end{array}$ & 33.0 & 8.9 & $\begin{array}{r}19 \\
277\end{array}$ & $\begin{array}{l}154 \\
123\end{array}$ & 400 \\
\hline 366 & Aug. 26,1909 & 8.5 & .....do. & 3.9 & 33.1 & 10.3 & 241 & 142 & 383 \\
\hline 367 & ..... do....... & 8.5 & ..do. & 13.4 & 13.8 & 5.8 & 177 & 80 & 257 \\
\hline 374 & $\ldots$ do & 13.0 & .. do... & 5.8 & 13.6 & 5.5 & 126 & 76 & 202 \\
\hline 128 & Aug. 17,1909 & 14.5 & Scattering. & 2.0 & 21.2 & 6.0 & 151 & 83 & 234 \\
\hline 129 & .....do......... & 12.5 & ..... do.. & 2.5 & 24.0 & 4.5 & 172 & 62 & 234 \\
\hline 130 & ..... do . ......... & 13.5 & .....do... & 1.5 & 9.5 & 5.5 & 71 & 76 & 147 \\
\hline 131 & ..... do $\ldots . . .$. & 9.5 & .....do.... & 5.5 & 24.0 & 5.5 & 192 & 76 & 268 \\
\hline 160 & Aug. 18,1909 & 9.0 & .....do... & 3.0 & 31.1 & 5.7 & 221 & 79 & 300 \\
\hline 161 & .................. & 9.0 & ..do. & 2.9 & 27.7 & 5.1 & 199 & 70 & 269 \\
\hline 368 & Aug. 26, 1909 & 8.5 & do.. & 10.0 & 28.6 & 1.8 & 251 & 25 & 276 \\
\hline 372 & ................ & 11.0 & 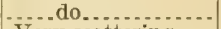 & 2.3 & 13.2 & 7.1 & 101 & 98 & 199 \\
\hline 162 & Aug. 18,1909 & 13.0 & Very scattering. & 1.2 & 13.5 & 2.4 & 97 & 33 & 130 \\
\hline 166 & & 15.5 & ....do.. & 2.7 & 45.9 & 5.5 & 316 & 76 & 392 \\
\hline 371 & Aug. 26,1909 & 14.0 & ..do.. & .0 & 4.5 & 3.3 & 29 & 46 & 75 \\
\hline 375 & .....do......... & 17.0 & ....do.. & .0 & 6.8 & 3. & 44 & 50 & 94 \\
\hline 376 & ..... do... & 13.0 & .... do & .0 & 4.5 & 3.8 & 29 & 52 & 81 \\
\hline 168 & Aug. 18,1909 & 9.5 & Depleted. & 1.3 & 18.5 & 1.8 & 129 & 25 & 154 \\
\hline 172 & .... do & 15.0 & ....do... & 2.7 & 24.6 & 2.7 & 177 & 37 & 214 \\
\hline 373 & Aug. 26, 1909 & 13.0 & ....do... & .0 & 1.2 & .9 & 8 & . 12 & 20 \\
\hline 377 & ......do.... & 13.0 & .....do. & .3 & 1.0 & .7 & 8 & 10 & 18 \\
\hline
\end{tabular}


BLUNT POINT ROCK.

This is the uppermost bed in that part of Public Ground No. 1, Warwick County, in which the cull law is enforced. All beds above this, excepting the small one in Warwick River, are within the area which is set apart for seed production. This rock is rather attenuated in most of its parts, being in the shape of an irregular ring surrounding a deeper barren area, with a long tail running along the Baylor line in the direction of Deep Creek. The highly productive area is very limited and the very scattering growth constitutes more than half of the total area. The extent and general condition of the bed at the time of the survey are shown in the following table:

Oyster Growth on Blunt Point Rock.

\begin{tabular}{|c|c|c|c|c|}
\hline \multirow{2}{*}{ Character of growth of market oysters. } & \multirow{2}{*}{ Area. } & \multicolumn{2}{|c|}{ Oysters per acre. } & \multirow{2}{*}{$\begin{array}{l}\text { Estimated } \\
\text { content of } \\
\text { market } \\
\text { oysters. }\end{array}$} \\
\hline & & Seed. & Market. & \\
\hline 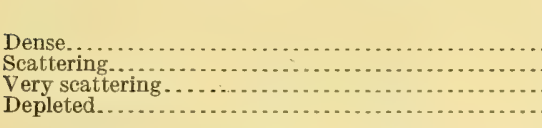 & $\begin{array}{r}\text { Acres. } \\
16 \\
69 \\
225 \\
118\end{array}$ & $\begin{array}{r}\text { Bushels. } \\
171 \\
193 \\
105 \\
42\end{array}$ & $\begin{array}{r}\text { Bushels. } \\
161 \\
60 \\
45 \\
14\end{array}$ & $\begin{array}{r}\text { Bushels. } \\
2,576 \\
4,140 \\
10,125 \\
1,652\end{array}$ \\
\hline Total. . & 428 & $\ldots$. & $\ldots$ & 18,493 \\
\hline
\end{tabular}

The bottom covered with a dense growth occurs on two small patches on small shoals, on which about 15 bushels of market oysters could be taken in a day.

There are three areas of scattering growth, of about equal productiveness so far as market oysters are concerned. One of these is at the extreme end of the rock off Deep Creek, which is in close proximity to planted beds and bears some indications of being itself planted ground. These areas as a whole will yield, it is estimated, an average of about 6 bushels per day.

The very scattering growth consists of a narrow zone almost encircling the included barren area above alluded to and a prolongation northward toward Deep Creek. The examinations made on it indicate a probable yield of about $3 \frac{1}{2}$ bushels per day of continuous tonging.

The depleted area skirts the preceding for a good part of its length, and in addition forms a projection on the western part of the bed and a small isolated patch on a shoal just beyond it. Its content of oysters is such that it could furnish the tonger with hardly more than a bushel per day.

The young growth is in good quantity on the dense and scattering areas of oysters, excepting that nearest Deep Creek, where it is practically absent. With the exception noted, the tonger should be able to gather about 15 bushels per day. On the narrow annular part of 
the beds the production of young oysters is good on the very scattering and depleted areas, which in their other parts are deficient in immature growth.

The following data furnish the basis for the foregoing:

Details of Examination of Blunt Point Rock.

\begin{tabular}{|c|c|c|c|c|c|c|c|c|c|}
\hline \multirow{2}{*}{$\begin{array}{c}\text { Station } \\
\text { num- } \\
\text { ber. }\end{array}$} & \multirow{2}{*}{$\begin{array}{l}\text { Date of ex- } \\
\text { amination. }\end{array}$} & \multirow{2}{*}{$\begin{array}{c}\text { Mean } \\
\text { depth } \\
\text { of wa- } \\
\text { ter. }\end{array}$} & \multirow{2}{*}{$\begin{array}{l}\text { Character of growth } \\
\text { of market oysters. }\end{array}$} & \multicolumn{3}{|c|}{$\begin{array}{l}\text { Oysters caught per } \\
\text { square yard. }\end{array}$} & \multicolumn{3}{|c|}{$\begin{array}{l}\text { Estimated quantity oys- } \\
\text { ters per acre. }\end{array}$} \\
\hline & & & & Spat. & Culls. & Counts: & Seed. & Market. & Total. \\
\hline & A $10 \% \quad 21,1099$ & Feet. & Dense & 7.9 & 17.5 & & Bush. & Bush. & Bush. \\
\hline $\begin{array}{l}252 \\
253\end{array}$ & $\begin{array}{r}\text { Aug, } 21,1909 \\
\ldots . . \text { do } \ldots . . .\end{array}$ & $\begin{array}{r}9.5 \\
12.5\end{array}$ & $\begin{array}{l}\text { Dense. } \\
\text {......do. }\end{array}$ & 3.1 & $\begin{array}{l}14.5 \\
24.5\end{array}$ & $\begin{array}{r}7.5 \\
15.9\end{array}$ & $\begin{array}{l}165 \\
178\end{array}$ & $\begin{array}{l}103 \\
219\end{array}$ & $\begin{array}{l}208 \\
397\end{array}$ \\
\hline 180 & Aug. 18,1909 & 12.5 & Scattering & 1.5 & 33.9 & 5.3 & 230 & 73 & 303 \\
\hline 187 & .... do....... & 6.5 & ..... do. & .0 & .8 & 3.5 & 5 & 48 & 53 \\
\hline 254 & Aug. 21, 1909 & 11.0 & ....do... & .3 & 22.9 & 4.2 & 151 & 58 & 209 \\
\hline 173 & Aug. 18,1909 & 16.0 & Very scattering. & .9 & 5. 0 & 4.6 & 38 & 63 & 101 \\
\hline 175 & ............... & 10.5 & ..... do.. & 2.6 & 42.3 & 3.5 & 292 & 48 & 340 \\
\hline 178 & ....do... & 10.5 & ......do. & 1.3 & 27.1 & 2.9 & 184 & 40 & 224 \\
\hline 182 & .....do... & 11.0 & ......do.. & 2.0 & 7.1 & 3.7 & 59 & 51 & 110 \\
\hline 188 & ...... do.. & 9.5 & ..... do. & .0 & 4. 0 & 2.0 & 26 & 28 & 54 \\
\hline 380 & Aug. 26, 1909 & 14.5 & .....do. & 1.0 & 3.1 & 4.1 & 27 & 57 & 84 \\
\hline 381 & ..... do....... & 13.0 & ...... do. & .3 & 16. 0 & 2.1 & 106 & 29 & 135 \\
\hline 174 & Aug. 18,1909 & 16.0 & Depleted. & 1.9 & 35.2 & 2.6 & 241 & 36 & 277 \\
\hline 177 & ..... do....... & 13.5 & ..... do... & .0 & .0 & .0 & 0 & 0 & 0 \\
\hline 179 & ..... do....... & 16.5 & $\ldots .$. do... & .0 & 3.6 & .9 & 23 & 7 & 30 \\
\hline 181 & .....do.. & 13.5 & ..... do.. & .0 & .0 & .0 & 0 & 0 & 0 \\
\hline 189 & .... do. & 8.5 & ....do. do. & 1.3 & 12,1 & 1.3 & 87 & 18 & 105 \\
\hline 190 & Aug. 19,1809 & 9.5 & ....... do & .0 & .0 & 1.3 & 0 & 18 & 18 \\
\hline 251 & Aug. 21,1909 & 11.5 & .....do & .8 & 2.9 & 1.3 & 24 & 18 & 42 \\
\hline 378 & Aug. 26,1909 & 12.5 & .....do... & .0 & .0 & 1.8 & 0 & 25 & 25 \\
\hline 379 & ..... do....... & 15.5 & ......do.. & .0 & .0 & .0 & 0 & 0 & 0 \\
\hline
\end{tabular}

WHITE SHOAL ROCKS.

These are two rocks in very shallow water, with slightly greater depths between and deep channels surrounding. The westernmost lies about a bare shell bank and the easternmost is nearly awash at low water.

The following exhibits their extent and condition at the beginning of the oyster season of 1909-10.

Oyster Growth on White Shoal Rocks.

\begin{tabular}{|c|c|c|c|c|}
\hline \multirow{2}{*}{ Character of growth of market oysters. } & \multirow{2}{*}{ Area. } & \multicolumn{2}{|c|}{ Oysters per acre. } & \multirow{2}{*}{$\begin{array}{l}\text { Estimated } \\
\text { content of } \\
\text { market } \\
\text { oysters. }\end{array}$} \\
\hline & & Seed & Market. & \\
\hline $\begin{array}{l}\text { Dense........... } \\
\text { Very scattering. } \\
\text { Depleted......... }\end{array}$ & $\begin{array}{r}\text { Acres. } \\
44 \\
10 \\
52\end{array}$ & $\begin{array}{r}\text { Bushets. } \\
312 \\
108 \\
53\end{array}$ & $\begin{array}{r}\text { Bushels. } \\
127 \\
36 \\
12\end{array}$ & $\begin{array}{r}\text { Bushels. } \\
5,588 \\
360 \\
624\end{array}$ \\
\hline Total...: & 106 & & & 6,572 \\
\hline
\end{tabular}

The dense areas produce a good quantity of marketable oysters and at the beginning of the present season should be capable of yielding about 12 bushels of oysters per full day of tonging. There are no areas of scattered growth within the definition of this report, but at 
each end of the western rock there is a small patch of very scattering growth capable of yielding an average of $3 \frac{1}{2}$ bushels of marketable oysters per day.

The area charted as depleted bears very few marketable oysters.

The young growth on the dense areas is very prolific, being in sufficient quantity to afford a daily return to the tonger of about 35 bushels. On the scattering bottom about 10 bushels per day could be taken, while on the depleted bottom as a whole the average would hardly exceed 4 bushels, although two or three times that many could be taken in places.

Details of Examination of White Shoal Rocks.

\begin{tabular}{|c|c|c|c|c|c|c|c|c|c|}
\hline \multirow{2}{*}{$\begin{array}{c}\text { Station } \\
\text { num- } \\
\text { ber. }\end{array}$} & \multirow{2}{*}{$\begin{array}{l}\text { Date of ex- } \\
\text { amination. }\end{array}$} & \multirow{2}{*}{$\begin{array}{c}\text { Mean } \\
\text { depth } \\
\text { of wa- } \\
\text { ter. }\end{array}$} & \multirow{2}{*}{$\begin{array}{l}\text { Character of growth } \\
\text { of market oysters. }\end{array}$} & \multicolumn{3}{|c|}{$\begin{array}{l}\text { Oysters caught per } \\
\text { square yard. }\end{array}$} & \multicolumn{3}{|c|}{$\begin{array}{l}\text { Estimated quantity oys- } \\
\text { ters per acre. }\end{array}$} \\
\hline & & & & Spat. & Culls. & Counts. & Seed. & Market. & Total. \\
\hline 169 & Aug. 18, 1909 & $\begin{array}{r}\text { Feet. } \\
5.5\end{array}$ & Dense & 7.7 & 92.3 & 6.5 & $\begin{array}{r}\text { Bush. } \\
650\end{array}$ & $\begin{array}{c}\text { Bush. } \\
{ }_{90}\end{array}$ & $\begin{array}{r}\text { Bush. } \\
740\end{array}$ \\
\hline 170 & Aus. do......... & 8.5 & ..... do. & 3.8 & 10.4 & 9.2 & 92 & $\begin{array}{l}90 \\
127\end{array}$ & 219 \\
\hline 443 & Sept. 1,1909 & 10.0 & .... do. & 11.7 & 63.3 & 7.1 & 487 & 98 & 585 \\
\hline 444 & ... do....... & 10.0 & .... do. & 11.7 & 29.6 & 17.9 & 268 & 247 & 515 \\
\hline 445 & . do.. & 13. 0 & do. & 15. 2 & 26.9 & 8.3 & 274 & 115 & 389 \\
\hline 447 & ....do & 9.5 & ... do. & 10.0 & 28.4 & 7.1 & 250 & 98 & 348 \\
\hline 556 & Sept. 14,1909 & 9.5 & ...do. & 6.1 & 26.2 & 11.6 & 210 & 160 & 370 \\
\hline 557 & ...do........ & 4.0 & do.................. & 11.5 & 29.3 & 5.7 & 265 & 79 & 344 \\
\hline 558 & ..do do... & 7.5 & Very scattering.... & 2.0 & 8.7 & 3.0 & 70 & 41 & 111 \\
\hline 562 & .... do. . & 10.5 & .......... & 2.6 & 19.7 & 2.3 & 145 & 32 & 177 \\
\hline 552 & do . & 9.0 & Depleted - & .3 & 1.3 & .3 & 10 & 4 & 14 \\
\hline 553 & do. & 8.5 & ....do... & 1.0 & 6.3 & 1.0 & 47 & 14 & 61 \\
\hline 554 & do.. & 6.5 & ..... do... & .3 & .0 & .0 & 2 & 0 & 2 \\
\hline 555 & do.. & 12.5 & ..... do... & 1.9 & 11.0 & 1.9 & 84 & 26 & 110 \\
\hline 559 & do.. & 10.5 & ....do.. & 4. 6 & 21.0 & 1.8 & 166 & 25 & 191 \\
\hline 561 & do. & 11.5 & ...do & .3 & .3 & .3 & 4 & 4 & \\
\hline
\end{tabular}

\section{SEED OYSTER AREA.}

JAIL ISLAND ROCK.

For this and all of the following rocks the standard of density of growth is different from that adopted in the preceding descriptions. The cull law, so far as it relates to the size of oysters, does not apply, and oysters of whatever size may be taken. The entire content of the bed, both young and old, is therefore taken into consideration, and as the average price of seed oysters is about two-thirds of that of the market oysters from the James River, a larger quantity has to be taken to furnish a living wage. In all of the following descriptions a bed is regarded as dense when 12 or more bushels may be taken by a tonger in a day's work, as scattering when it will yield between 8 and 12 bushels, very scattering when it yields between 4 and 8 , and depleted if less than 4 bushels can be tonged per day. As the market oysters sell for 45 cents and the seed oysters for but 30 cents per bushel, the financial return is essentially equal.

Jail Island Rock, which extends alongshore west of the mouth of Warwick River, is continuous at its offshore edge with Wreck Shoal 
Rock, the boundary between them as adopted in this report being purely arbitrary.

The extent and general condition of the bed at the time of the survey was as follows:

Oyster Growth on JaIl Island Rock.

\begin{tabular}{|c|c|c|c|}
\hline Character of growth. & Area. & $\begin{array}{l}\text { Oysters } \\
\text { per acre. }\end{array}$ & $\begin{array}{l}\text { Estimated } \\
\text { content } \\
\text { of oysters. }\end{array}$ \\
\hline 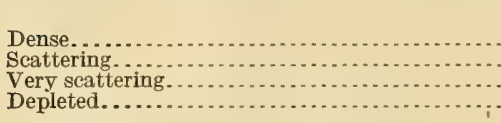 & $\begin{array}{r}\text { Acres. } \\
227 \\
198 \\
14 \\
508\end{array}$ & $\begin{array}{r}\text { Bushels. } \\
143 \\
109 \\
28 \\
8\end{array}$ & $\begin{array}{r}\text { Bushels. } \\
32,461 \\
21,582 \\
392 \\
4,064\end{array}$ \\
\hline Total. - & 947 & $\ldots$ & 58,499 \\
\hline
\end{tabular}

The principal area of dense growth runs from the inner edge of Wreck Shoal Rock in a gradually narrowing belt to a tongue extending to within 200 or 300 yards of shore between Jail Island and the mouth of Warwick River. The depth of water gradually decreases from about 9 feet to 2 or 3 feet at low water, near Jail Island. There is also a small area of dense growth lying on an isolated patch in about 10 or 11 feet of water off the mouth of Warwick River, which, being just on the cull line, is arbitrarily included in the Jail Island bed for the purposes of this report. The dense bottom as a whole will afford the tonger an average catch per day of about 17 bushels of oysters of all sizes.

The area of scattering growth lies in a single body north and west of the preceding in from 6 to 11 feet of water. The growth on the whole is rather heavier in the deeper water, and as an average should yield approximately 9 bushels per day.

The very scattering growth is in a small patch immediately east of Jail Island, where the yield to the tonger should be about 5 bushels per day.

The depleted bottom forms a broad zone on the inshore side and a narrow strip on the eastern edge of the bed. There is also a depleted area adjoining the small, isolated, dense patch before described, and a small patch lying between that and the main bed. In most places the so-called "depleted bottom" is practically bare. There is but a moderate supply of shells on the dense area and on the scattering area close to it, but elsewhere the bed is deficient in this respect.

It is stated that the inshore portions of the bed, on the depleted bottom along the Baylor line, produce fine single oysters, which in calm weather are picked up one by one and bring a high price in the markets. The survey did not disclose any quantity of such oysters. 
Details of Examination of Jail Island Rock.

\begin{tabular}{|c|c|c|c|c|c|c|c|}
\hline \multirow{2}{*}{$\begin{array}{c}\text { Station } \\
\text { num- } \\
\text { ber. }\end{array}$} & \multirow{2}{*}{$\begin{array}{l}\text { Date of ex- } \\
\text { amination. }\end{array}$} & \multirow{2}{*}{$\begin{array}{c}\text { Mean } \\
\text { depth } \\
\text { of wa- } \\
\text { ter. }\end{array}$} & \multirow{2}{*}{ Character of growth. } & \multicolumn{3}{|c|}{$\begin{array}{l}\text { Oysters caught per } \\
\text { square yard. }\end{array}$} & \multirow{2}{*}{$\begin{array}{c}\text { Estimated } \\
\text { quantity } \\
\text { oysters per } \\
\text { acre. }\end{array}$} \\
\hline & & & & Spat. & Culls. & Counts. & \\
\hline & & Feet. & & & & & Bushels. \\
\hline $\begin{array}{l}184 \\
198\end{array}$ & $\begin{array}{l}\text { Aug. 18, } 1909 \\
\text { Aug. } 19,1909\end{array}$ & $\begin{array}{r}\text { 11. } 0 \\
7.0\end{array}$ & Dense.. & $\begin{array}{l}1.3 \\
1.7\end{array}$ & $\begin{array}{l}49.0 \\
12.1\end{array}$ & $\begin{array}{l}4.6 \\
2.5\end{array}$ & $\begin{array}{r}306 \\
97\end{array}$ \\
\hline 199 & ..... do........ & 6. 0 & do. & .0 & 8.5 & 6.9 & 138 \\
\hline 200 & .... do ........ & 4. 0 & do & 1.5 & 8.8 & 4. 2 & 110 \\
\hline 404 & Aug. 27,1909 & 4. 0 & do & 1.3 & 3.3 & 2.8 & 62 \\
\hline 207 & Aug. 19,1909 & 10.0 & Scattering. & 4. 6 & 8.2 & 2.1 & 88 \\
\hline 210 & . . do......... & 11.5 & .....do.. & 5.4 & 16. 7 & 2.5 & 140 \\
\hline 211 & ....do... & 8. 5 & do. & .0 & 2.7 & 6.2 & 99 \\
\hline 402 & Aug. 27, 1909 & 4.0 & Very scattering. & i. 1 & 1.9 & .9 & 28 \\
\hline 183 & Aug. 18, 1909 & 11. 0 & Depleted....... & .0 & .0 & .0 & 0 \\
\hline 185 & .... do....... & $\cdot 12.0$ & ..... do ... & .4 & 1.7 & 1.3 & 32 \\
\hline 192 & Aug. 19,1909 & 9.0 & ......do. do. & .0 & .0 & .7 & 8 \\
\hline 208 & ..... do........... & 7.5 & do.... do & .0 & .0 & .0 & 0 \\
\hline 212 & ... do do & 6.5 & do. & .0 & .3 & .3 & 6 \\
\hline 401 & Aug. 27, 1909 & 5.5 & ....do do.... & .7 & .7 & .0 & 7 \\
\hline 403 & ..... do........ & 4. 0 & .....do.. & .0 & .0 & .0 & 0 \\
\hline
\end{tabular}

WRECK SHOAL ROCK.

This is a large, important, and productive bed extending from the preceding to the edge of deep water. For the purposes of this report, it is regarded as including the oyster growth on and about Wreck Shoal proper and the small shoal to the westward of its outer end. Excepting where it adjoins Jail Island bed, its boundaries are rather sharply defined by a sudden shoaling of the water. This is especially pronounced at the southern edge of the bed, where the bottom very abruptly rises from about 150 feet to within 6 feet of the surface. North of the smaller shoal the bed is prolonged into a narrow belt occupying a slightly shoaling ridge connected with a corner of Mulberry Swash Rock. The depth at low water varies from less than 5 feet on the shoals to 12 or 15 feet at the edges. On one small area projecting as a tongue from the southeast side the water reaches a maximum depth of 30 feet.

Wreck Shoal Rock is practically everywhere highly productive and no part of it falls below the standard here regarded as constituting denseness of growth. Accepting the arbitrary inner boundary here adopted, it has an area of about 506 acres. The oyster growth at the places examined ranges from 178 to 497 bushels per acre, the average being about 316 . The heaviest growth is as a rule found on the shoaler places, which facilitates the removal of the product. This materially raises the average daily yield to the tonger, which ranges in different places from 12 bushels to 51 bushels, with a general average for the entire bed of over 29 bushels.

The bottom is well covered with clean shells and the bed can be regarded as being in a healthy and promising condition. In a few places there is a fair growth of large oysters and on the bed as a 
whole the young growth over 1 inch in length is numerically more than double that under 1 inch.

The following table exhibits the data obtained from the several examinations made:

Detalls of Examination of Wreck Shoal Rock.

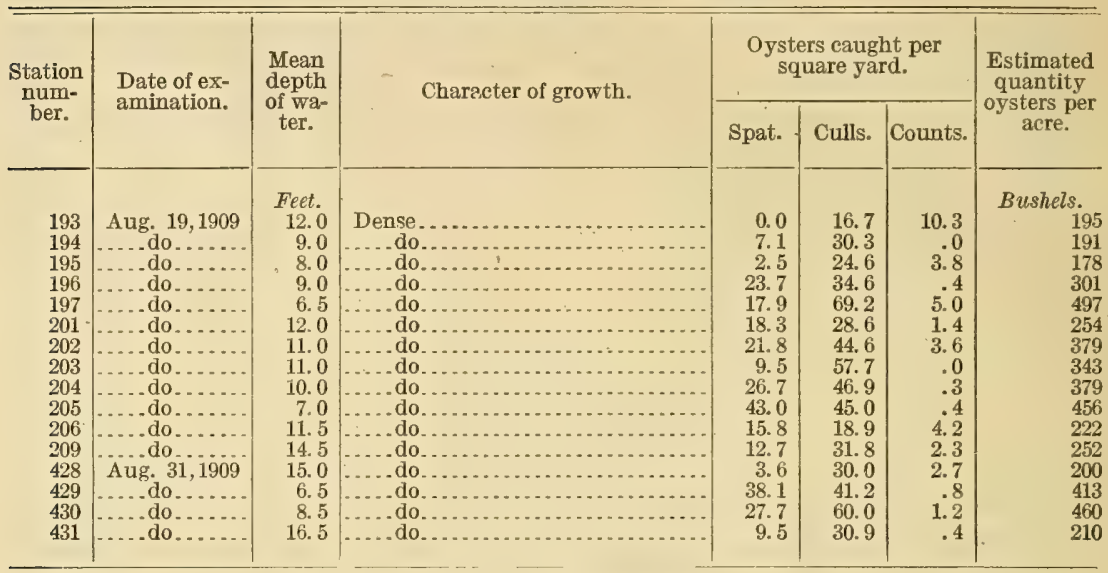

DRY SHOALS ROCKS.

These are 5 small rocks lying west of the preceding on and about shoals which ebb nearly or quite bare. They are in general isolated and surrounded by deep water, though two of them are connected by narrow ridges of depleted bottom with Swash Rock and Mulberry Swash Rock, respectively.

Their present condition and extent are shown in the following table:

Oyster. Growth on Dry Shoals Rocks.

\begin{tabular}{|c|c|c|c|}
\hline Character of growth. & Area. & $\begin{array}{c}\text { Oysters } \\
\text { per acre. }\end{array}$ & $\begin{array}{l}\text { Estimated } \\
\text { total con- } \\
\text { tent of } \\
\text { oysters. }\end{array}$ \\
\hline 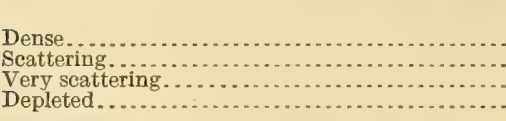 & $\begin{array}{r}\text { A cres. } \\
126 \\
18 \\
9 \\
21\end{array}$ & \begin{tabular}{|r|} 
Bushels. \\
244 \\
124 \\
85 \\
20
\end{tabular} & $\begin{array}{r}\text { Bushels. } \\
30,766 \\
2,232 \\
765 \\
420\end{array}$ \\
\hline Total... & 174 & & 34,183 \\
\hline
\end{tabular}

Four of these rocks are composed wholly or in major part of bottom bearing a dense growth of oysters, while the fifth, the smallest, bears a scattering growth exclusively. The dense growth in its daily yield to the tonger varies, with the locality, between 13 and 59 bushels, the average density over the entire area being sufficient to permit a 
daily catch of about 30 bushels per man. The average depth of water is about 5 to 7 feet at low tide.

The scattering growth is found in two places, one an isolated rock of small size and the other at the extremity of a larger bed where the productive bottom runs off to deeper water. There is not much difference in the density of the growth on the two places, and it is estimated that on the two a tonger could take an average of about 10 bushels of oysters per day.

The very scattering bottom lies in two small patches at opposite ends of the longest bed of the group, and the growth is so sparse as barely to remove the areas from the category of depleted bottom. The depleted areas are three in number, one in the deeper water at the tip of a rock and the others on the two connecting ridges mentioned earlier in this description. About the same numerical proportion exists between the culls and spat as on the preceding bed, and at one place on the dense area there is a good growth of marketable oysters averaging between 400 and 450 per bushel. There is a fair or good deposit of shells throughout the dense and scattering areas and on the apical area of very scattering growth, but elsewhere the rocks are deficient in this respect.

Details of Examination of Dry Shoals Rocks.

\begin{tabular}{|c|c|c|c|c|c|c|c|}
\hline \multirow{2}{*}{$\begin{array}{c}\text { Station } \\
\text { num- } \\
\text { ber. }\end{array}$} & \multirow{2}{*}{$\begin{array}{l}\text { Date of ex- } \\
\text { amination. }\end{array}$} & \multirow{2}{*}{$\begin{array}{l}\text { Mean } \\
\text { depth } \\
\text { of wa- } \\
\text { ter. }\end{array}$} & \multirow{2}{*}{ Character of growth. } & \multicolumn{3}{|c|}{$\begin{array}{l}\text { Oysters caught per } \\
\text { square yard. }\end{array}$} & \multirow{2}{*}{$\begin{array}{l}\text { Estimated } \\
\text { quantity } \\
\text { oysters per } \\
\text { acre. }\end{array}$} \\
\hline & & & & Spat. & Culls. & Counts. & \\
\hline 340 & Aug 25.1909 & Feet. & Dense. & & & & Bushels. \\
\hline $\begin{array}{l}340 \\
341\end{array}$ & Aug 20,1909 & 7.0 & Dense............ do & $\begin{array}{l}10.4 \\
11.7\end{array}$ & $\begin{array}{l}26.4 \\
30.0\end{array}$ & $\begin{array}{l}0.0 \\
4.2\end{array}$ & $\begin{array}{l}218 \\
258\end{array}$ \\
\hline 342 & .... do...... & 5.0 & . & 21.9 & 38.5 & 2.3 & .343 \\
\hline 347 & .... do....... & 11.0 & 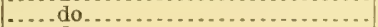 & 5.1 & 20.9 & 2.0 & 154 \\
\hline 348 & .... do... & 10.0 & . . do do & 10.6 & 36.6 & .6 & 247 \\
\hline 349 & ..... do.. & 5.0 & ... . do. . . . . . . . & 20.3 & 57. 7 & .0 & 398 \\
\hline 351 & ..... do.. & 5. 5 & 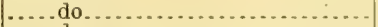 & 13.3 & 14.0 & 1.3 & 153 \\
\hline 352 & ..... do....... & 5.5 & ... do & 9.7 & 15.3 & .3 & 130 \\
\hline 438 & Aug. 31, 1909 & 7.0 & 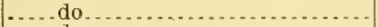 & 15. 7 & 21.3 & .7 & 195 \\
\hline 439 & .... do....... & 8.0 & .... do ...................... & 11. 1 & 43.0 & 12.3 & 408 \\
\hline 440 & ..... do... & 6.0 & $\ldots$ do.... & 15. 4 & 23.6 & .4 & 203 \\
\hline 343 & Aug. 25, 1909 & 14.0 & Seattering..... & 3.1 & 11.4 & 4.0 & 117 \\
\hline 442 & Aug. 31, 1909 & 12.0 & 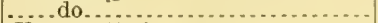 & 5.8 & 19.3 & .3 & 131 \\
\hline 337 & Aug. 25,1909 & 11.0 & Very scattering. & .8 & 2.5 & 2.9 & 48 \\
\hline 344 & .... do ....... & 17.0 & ...do.......... & 6.1 & 11.2 & 3.1 & 121 \\
\hline 437 & Aug. 31, 1909 & 14. 0 & Depleted............... & .0 & 1.8 & .9 & 19 \\
\hline 441 & .... do....... & -9.0 & ..... do . . .................... & .0 & 1.4 & 1.4 & 22 \\
\hline
\end{tabular}

POINT OF SHOALS ROCK.

This name is here given to a large area of varying productiveness lying between the preceding, Long Shoal and Point of Shoals Lighthouse, but it is possible that the name as used by the oystermen may not strictly accord with this usage. Scattered over the area are a number of small shoals ebbing nearly or quite bare, but the average depth is in general between 6 and 8 feet. Excepting at its northern edge, where an imaginary line separates it from Long Shoal Rock, 
the bed is everywhere bounded by the deep water of the ship channel or a swash channel which separates it from Dry Shoals and Swash Rocks. Where it faces the ship channel there is for most of the distance a border of barren bottom lying between the bed proper and deep water.

The condition and extent of the bed at the time of the survey was as follows:

Oyster Growth on Point of Shoals Rock.

\begin{tabular}{|c|c|c|c|}
\hline Character of growth. & Area. & $\begin{array}{l}\text { Oysters } \\
\text { per } \\
\text { acre. }\end{array}$ & $\begin{array}{l}\text { Total con- } \\
\text { tent of } \\
\text { oysters. }\end{array}$ \\
\hline 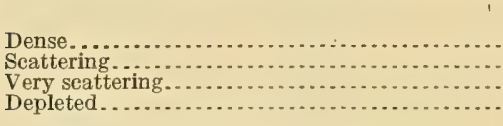 & $\begin{array}{r}\text { Acres. } \\
254 \\
155 \\
239 \\
142 \\
\end{array}$ & $\begin{array}{r}\text { Bushels. } \\
200 \\
93 \\
42 \\
15 \\
\end{array}$ & $\begin{array}{r}\text { Bushels. } \\
50,800 \\
14,415 \\
10,038 \\
2,130\end{array}$ \\
\hline Total....... & 790 & & 77,383 \\
\hline
\end{tabular}

The dense areas are three, one near the eastern end of the bed, another adjoining the corresponding area of Long Shoal Rock, and the third an isolated spot on a shoal in the swash channel. The densest growths occur as a rule on the shoaler spots, especially at the eastern end of the bed, from the isolated area above alluded to to the ship channel. In this area the average growth is about 275 bushels of oysters to the acre-considering the depths, sufficient to yield about 38 bushels per day's tonging-while the average of the whole area of dense growth would not exceed 25 bushels per day.

There are four scattering areas, one of which, near the eastern apex of the bed, is insignificant. On these as a whole a tonger should average, at the beginning of the season, about 10 bushels per day.

The very scattering growth is distributed in three areas, of which one adjoins the dense growth on the isolated patch in the swash channel. They are barely prolific enough to raise them above the assumed limit of depletion.

The depleted area is in five patches or borders along the free boundary of the bed. They are entirely negligible in their productiveness.

On the dense and scattering areas the proportion of very small to small oysters is higher than on the beds previously described, and there are several places on each where the growth of oysters above 3 inches long is fair.

On the dense areas the deposit of shells is abundant, on the areas of scattering growth it is ample, while the areas with a very scattering growth and the depleted bottoms are decidedly deficient. In general the latter two areas are of no present and little prospective value. 
Detalls of Examination of Ponnt of Shonls Rock.

\begin{tabular}{|c|c|c|c|c|c|c|c|}
\hline \multirow{2}{*}{$\begin{array}{c}\text { Station } \\
\text { num- } \\
\text { ber. }\end{array}$} & \multirow{2}{*}{$\begin{array}{l}\text { Date of ex- } \\
\text { amination. }\end{array}$} & \multirow{2}{*}{$\begin{array}{c}\text { Mean } \\
\text { depth } \\
\text { of wa- } \\
\text { ter. }\end{array}$} & \multirow{2}{*}{ Charaeter of growth. } & \multicolumn{3}{|c|}{$\begin{array}{l}\text { Oysters caught per } \\
\text { square yard. }\end{array}$} & \multirow{2}{*}{$\begin{array}{l}\text { Estimated } \\
\text { quantity } \\
\text { oysters per } \\
\text { acre. }\end{array}$} \\
\hline & & & & Spat. & Culls. & Counts. & \\
\hline & & Feet. & & & & & Bushels. \\
\hline 321 & Aug. 25, 1909 & 5. 0 & Dense........................ & 8.7 & 10.5 & 0.3 & 101 \\
\hline 327 & $\ldots$ do ........ & 5.5 & . & 11.9 & 10.3 & .3 & 116 \\
\hline 328 & $\ldots$. do $\ldots . . .$. & 7.5 & . . . do . . . . . . . . . . . . & 7. 7 & 9.3 & 7. 0 & 162 \\
\hline 329 & do . & 7.5 & do & 17.3 & 23.3 & 4.3 & 253 \\
\hline 334 & do.. & 8.5 & 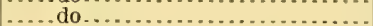 & 8.7 & 33.4 & 1.3 & 229 \\
\hline 336 & ...... do... & 4.0 & . do............. & 33.9 & 34.8 & .3 & 353 \\
\hline 356 & .... do... & 10.0 & .... do . . . . . . . & 4.3 & 16. 0 & 5.7 & 165 \\
\hline 311 & Aug. 24,1909 & 7.5 & Seattering & 8.0 & 6. & .7 & 81 \\
\hline 319 & Aug. 25, 1909 & 7.0 & do ............. & .2 & 5. & 4. 3 & 76 \\
\hline 335 & .... do....... & 7.5 & do & 6.2 & 13.3 & .4 & 104 \\
\hline 354 & ...... do . . & 8.0 & ... do . . . . . . . & .8 & 5.0 & 5.8 & 92 \\
\hline 358 & ..... do.. & 8.0 & ..... do ......... . & 2.0 & 6. 3 & 6.7 & 114 \\
\hline 308 & Aug. 24, 1909 & 7.5 & Very scattering...... & .0 & 1.0 & 5. 6 & 65 \\
\hline 310 & $\ldots .$. do....... & 7.5 & 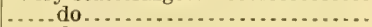 & .3 & . & .3 & 5 \\
\hline 320 & Aug. 25, 1909 & 7.0 & do & .7 & 2.3 & 1. 7 & 34 \\
\hline 357 & do... & 8. 0 & ... do .......... & 1.3 & 2.7 & 2.7 & 50 \\
\hline 527 & Sept. 11,1909 & 6.5 & .... do.... & .5 & 4.0 & 2.9 & 54 \\
\hline 309 & Aug. 24, 1909 & 7.5 & Depleted ..... & .0 & .0 & .0 & 0 \\
\hline 326 & Aug. 25, 1909 & 9.5 & ... do ......... & .0 & 0 & 1. 1 & 12 \\
\hline 333 & do & 10.5 & do & 1.7 & 2.1 & 1.7 & 38 \\
\hline 355 & ...... do.. & 9.0 & $\ldots$ do.......... & 0 & 0 & .0 & 0 \\
\hline 531 & Sept. 11,1909 & 7.0 & .... do.............. & .0 & 2.4 & 1.1 & 24 \\
\hline
\end{tabular}

SWASH ROCK.

This bed lies inshore of the preceding, nearly surrounded by swash channels. It is connected by narrow isthmuses with Long Shoal and Dry Shoal Rocks and adjoins $\mathrm{V}$ Rock to the westward. It consists of a dense area surrounding two shoals ebbing bare, and two depleted areas which connect it with adjoining beds.

Its condition and extent in August, 1909, was as follows:

Oyster Growth on Swash Rock.

\begin{tabular}{|c|c|c|c|}
\hline Character of growth. & Area. & $\begin{array}{l}\text { Oysters } \\
\text { per acre. }\end{array}$ & $\begin{array}{l}\text { Estimated } \\
\text { total con- } \\
\text { tent of } \\
\text { oysters. }\end{array}$ \\
\hline Dense & $\begin{array}{r}\text { Acres. } \\
146 \\
115\end{array}$ & $\begin{array}{r}\text { Bushels. } \\
293 \\
15\end{array}$ & $\begin{array}{r}\text { Bushels. } \\
42,778 \\
1,725\end{array}$ \\
\hline Total. & 261 & & 44,503 \\
\hline
\end{tabular}

The dense area as a whole is prolific in its product, but the middle part of the bed, between the shoal spots, is less densely covered than the surrounding area. It is estimated that at the beginning of the season a tonger could take an average of about 39 bushels of oysters per day. The covering of clean shells is sufficient to guarantee a good strike under favorable conditions. The depleted bottom is practically bare of oysters and shells and is at present and potentially worthless under natural conditions. 
The following examinations were made during the survey:

Details of Examination of Swash Rock.

\begin{tabular}{|c|c|c|c|c|c|c|c|}
\hline \multirow{2}{*}{$\begin{array}{c}\text { Station } \\
\text { num- } \\
\text { ber. }\end{array}$} & \multirow{2}{*}{$\begin{array}{l}\text { Date of ex- } \\
\text { amination. }\end{array}$} & \multirow{2}{*}{$\begin{array}{l}\text { Mean } \\
\text { depth } \\
\text { of wa- } \\
\text { ter. }\end{array}$} & \multirow{2}{*}{ Character of growth. } & \multicolumn{3}{|c|}{$\begin{array}{l}\text { Oysters caught per } \\
\text { square yard. }\end{array}$} & \multirow{2}{*}{$\begin{array}{l}\text { Estimated } \\
\text { quantity } \\
\text { oysters per } \\
\text { acre. }\end{array}$} \\
\hline & & & & Spat. & Culls. & Counts. & \\
\hline 324 & Aug. 25, 1909 & $\begin{array}{r}\text { Feet. } \\
5.0\end{array}$ & Dense.. & 29.2 & 41.4 & 0.0 & Bushels. \\
\hline 325 & ..... do........ & 7.0 & & 12.3 & 17.3 & 7.0 & 226 \\
\hline 228 & Aug. 20,1909 & 12.0 & Depleted. & .0 & .0 & .0 & 0 \\
\hline 323 & Aug. 25, 1909 & 9.0 & do... d & .0 & 1.2 & 1.9 & 27 \\
\hline 437 & Aug. 31, 1909 & 14.0 & .... do & .0 & 1.8 & .9 & 19 \\
\hline
\end{tabular}

MULBERRY SWASH ROCK.

This is a long narrow bed lying between Swash and V rocks on the outside and the so-called Marshy Island Rock on the shoreward side. At its southeastern end it is connected by narrow strips of indifferent productiveness with Wreck Shoal and Dry Shoal rocks, and its offshore boundary is the edge of the deep swash channel running toward Mulberry Point.

It consists essentially of bottom carrying a dense growth, interrupted at two places by areas of inferior productiveness. Its condition and extent in the latter part of August, 1909, are shown in the following table:

Orster Growth on Mulberry Swash Rock.

\begin{tabular}{|c|c|c|c|}
\hline Character of growth. & Area. & $\begin{array}{c}\text { Oysters } \\
\text { per acre. }\end{array}$ & $\begin{array}{l}\text { Estimated } \\
\text { total con- } \\
\text { tent of oys- } \\
\text { ters. }\end{array}$ \\
\hline 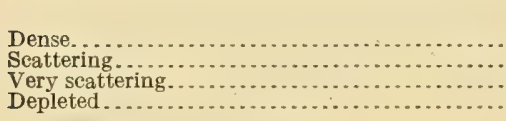 & $\begin{array}{r}\text { Acres. } \\
422 \\
34 \\
20 \\
29\end{array}$ & \begin{tabular}{|r|} 
Bushels. \\
302 \\
106 \\
130 \\
43
\end{tabular} & $\begin{array}{r}\text { Bushels. } \\
127,444 \\
3,604 \\
2,600 \\
1,247\end{array}$ \\
\hline Total...... & 505 & & 134,895 \\
\hline
\end{tabular}

The dense area bears a growth varying from 161 to 570 bushels per acre, and the depths vary from 8 to upward of 20 feet. The heavier growth is as a rule in the shoaler water, though this rule is not without exceptions. It is estimated that a tonger could take an average of about 23 bushels per day at the beginning of the season.

The scattered area is limited in extent and bears a growth of between 88 and 117 bushels per acre, in a depth of between 13 and 15 feet, and it is estimated that it will yield about 8 bushels per day.

The area of very scattering growth connects this bed with Wreck Shoal Rock, and although, as shown by the foregoing table, the growth is heavier than on the preceding area, it lies in between 18 and 20 feet of water and will therefore be less productive to the tonger, its estimated initial yield being about 7 bushels per day. The depleted area is in several small patches. 
There is an abundant supply of shells on the dense area, a quantity of doubtful sufficiency on the bottoms bearing scattering and very scattering growths, and a deficiency on the depleted bottom.

Detalls of Examination of Mulberry Swash Rock.

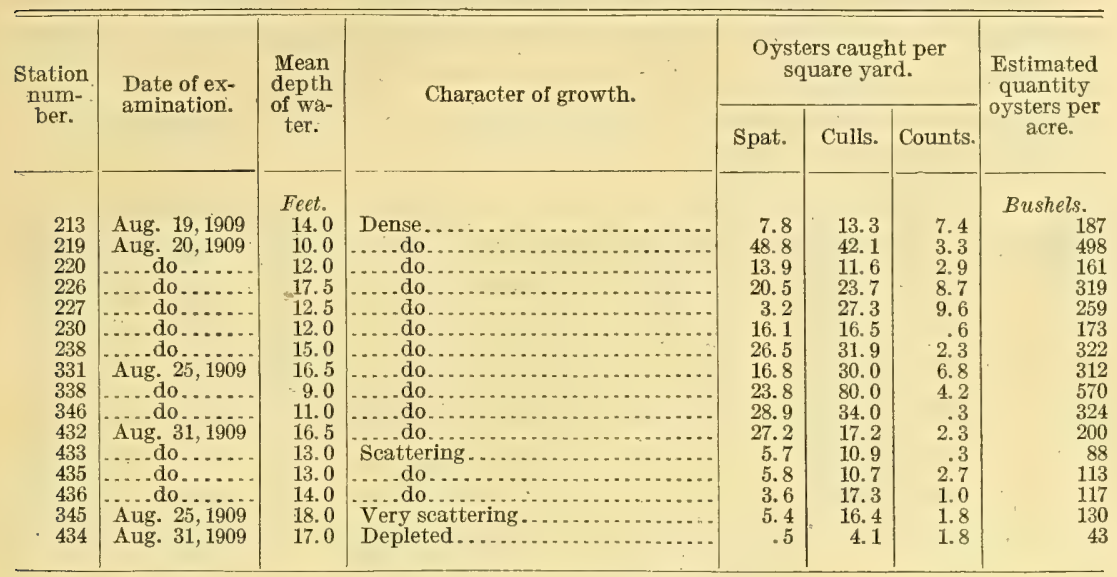

MARSHY ISLAND ROCK.

This lies between Mulberry Swash Rock and the inshore boundary of the public ground, principally in the "addition" which was made a part of the ground subsequent to the Baylor survey. The name here employed is coined for the purpose of this report, as the name by which this area of oyster bottom is known to the oystermen, if it has a distinctive name, was not ascertained by the survey. The outer or offshore boundary of the bed is defined more or less sharply by a channel, carrying a maximum of from 21 to 27 feet of water, between this and Mulberry Swash Rock.

The condition and extent of this bed about the middle of August, 1909, was as follows:

Oyster Growth on Marshy Island Rock.

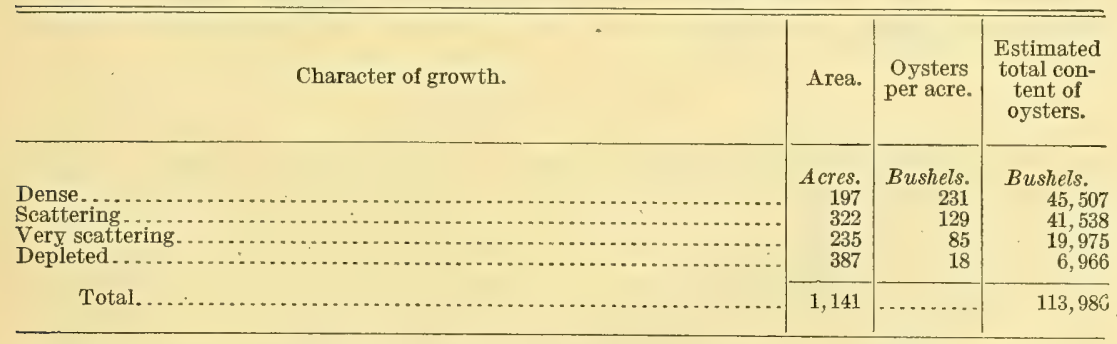

The dense areas lie in three isolated patches which exhibit no material shoaling over the surrounding bottom, except where they touch the channel which bounds the bed offshore. The depth of water on

$$
20201-10-4
$$


the several areas ranges between 6 and 16 feet, and the density of growth between 142 and 410 bushels per acre. It is estimated that the bottoms are capable of producing an initial yield of about 18 bushels per day.

The scattering area occupies a general central position in the bed surrounding one of the dense spots. The depth varies from 10 feet inshore to about 22 feet at the edge of the channel, and the quantity of oysters varies between 92 and 186 bushels per acre. The estimated daily yield to the tonger is about 10 bushels.

The bottom covered by a very scattering growth forms a zone encircling the inner edge of the preceding. It lies in a depth varying from 7 to 16 feet, and, although the examinations were not as numerous as they should have been, they indicate that the growth is sufficient to yield an average of between 6 and 7 bushels per day.

The depleted bottom lies in a belt on the inside edge of the bed. It is practically bare of oysters and shells.

Shells are found in fair quantities on the dense bottom and on the outer parts of the scattering growth, but are deficient on the inshore parts of the latter, on most of the area of very scattering growth, and on the depleted area.

The following observations were made:

Details of Examination of Marshy Island Rock.

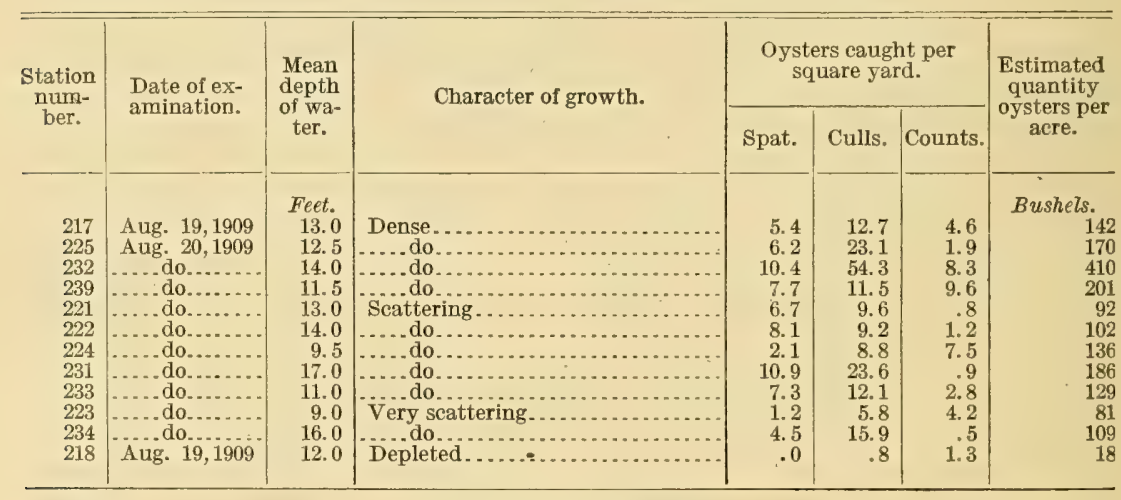

LONG SHOAL ROCK.

This triangular bed flanks a shoal, ebbing bare in many places, which extends eastwardly from Point of Shoals light-house for a distance of upward of $1 \frac{1}{2}$ miles. As understood in this report, its boundary is an imaginary line running from Point of Shoals light toward Jail Island at an average distance of about 300 to 400 yards from the crest of the shoal, as far as the swash channel opening toward the northwest, along the edge of this channel to its mouth, and thence to the starting point. The main body of the rock, therefore, lies north of the crest of the bar. Its condition and extent about the beginning of September, 1909, were as follows: 
Oyster Growth on Long Shoal Rock.

\begin{tabular}{|c|c|c|c|}
\hline Character of growth. & Area. & $\begin{array}{l}\text { Oysters } \\
\text { per acre. }\end{array}$ & $\begin{array}{l}\text { Estimated } \\
\text { total con- } \\
\text { tent of } \\
\text { oysters. }\end{array}$ \\
\hline $\begin{array}{l}\text { Dense } \\
\text { Dentto }\end{array}$ & $\begin{array}{r}\text { Acres. } \\
331\end{array}$ & $\begin{aligned} & \text { Bushels. } \\
& 241\end{aligned}$ & $\begin{array}{l}\text { Bushels. } \\
\quad 79,771\end{array}$ \\
\hline $\begin{array}{l}\text { Scattering } \\
\text { Very scattering. } \\
\text { Depleted }\end{array}$ & $\begin{array}{l}10 \\
84 \\
79\end{array}$ & $\begin{array}{l}64 \\
60 \\
16\end{array}$ & $\begin{array}{r}640 \\
5,040 \\
1,264\end{array}$ \\
\hline Total.. & 504 & & 86,715 \\
\hline
\end{tabular}

A dense growth of small oysters, with a good proportion of larger ones in a few spots, covers the major part of the bed. At various places the total growth varies between 148 and 364 bushels per acre, and it is estimated that at the beginning of the season a tonger could take about 28 bushels per day.

The scattering growth is comprised in one small spot about 100 to 200 yards from the light-house, where about 9 bushels per day may be taken.

The very scattering growth lies in two small patches along the western border of the bed and a larger area south of the ridge is continuous with similar bottom on Point of Shoals Rock. It is capable of yielding between 6 and 7 bushels per day. The depleted area lies south of the outer half of the ridge, with a small patch on the swash channel. It is practically bare of oysters and shells.

The areas bearing oysters in dense and scattering growth are covered with a supply of shells amply sufficient to serve the purposes of cultch. The small patches of very scattering growth are also fairly covered, but the large area south of the ridge and the depleted area adjoining are deficient.

The following observations were made:

Details of Examination of Long Shoal Rock.

\begin{tabular}{|c|c|c|c|c|c|c|c|}
\hline \multirow{2}{*}{$\begin{array}{c}\text { Station } \\
\text { num- } \\
\text { ber. }\end{array}$} & \multirow{2}{*}{$\begin{array}{l}\text { Date of ex- } \\
\text { amination. }\end{array}$} & \multirow{2}{*}{$\begin{array}{c}\text { Mean } \\
\text { depth } \\
\text { of wa- } \\
\text { ter. }\end{array}$} & \multirow{2}{*}{ Character of growth. } & \multicolumn{3}{|c|}{$\begin{array}{l}\text { Oysters caught per } \\
\text { square yard. }\end{array}$} & \multirow{2}{*}{$\begin{array}{l}\text { Estimated } \\
\text { quantity } \\
\text { oysters per } \\
\text { aere. }\end{array}$} \\
\hline & & & & Spat. & Culls. & Counts. & \\
\hline $\begin{array}{l}295 \\
296 \\
298 \\
299 \\
300 \\
301 \\
313 \\
318 \\
322 \\
529 \\
541 \\
297 \\
312 \\
538 \\
307 \\
528 \\
534 \\
535 \\
539 \\
510\end{array}$ & 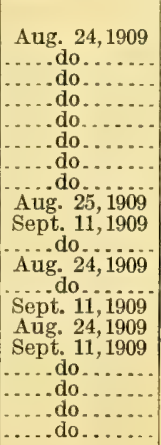 & $\begin{array}{r}\text { Feet. } \\
8.0 \\
10.0 \\
12.5 \\
6.5 \\
6.5 \\
7.5 \\
8.0 \\
6.0 \\
5.0 \\
5.0 \\
6.0 \\
11.0 \\
9.0 \\
4.0 \\
8.5 \\
6.5 \\
7.0 \\
7.0 \\
6.0 \\
6.0\end{array}$ & 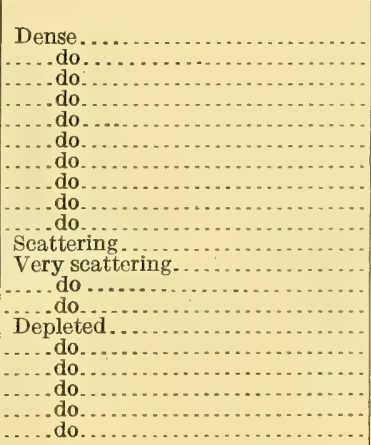 & $\begin{array}{r}25.8 \\
20.4 \\
11.9 \\
22.8 \\
19.2 \\
20.3 \\
19.7 \\
40.7 \\
19.0 \\
1.1 \\
6.1 \\
2.1 \\
3.9 \\
1.4 \\
.0 \\
1.3 \\
.0 \\
.2 \\
.5\end{array}$ & $\begin{array}{r}29.7 \\
25.4 \\
13.4 \\
17.1 \\
10.0 \\
7.3 \\
25.8 \\
30.7 \\
4.6 \\
21.4 \\
6.6 \\
4.5 \\
3.3 \\
3.2 \\
1.1 \\
1.1 \\
3.4 \\
.5 \\
.5 \\
.5\end{array}$ & $\begin{array}{r}2.3 \\
.4 \\
9.6 \\
2.5 \\
12.5 \\
.7 \\
.0 \\
.0 \\
13.1 \\
.0 \\
2.3 \\
1.9 \\
4.2 \\
.0 \\
2.5 \\
.5 \\
.3 \\
.3 \\
.2 \\
.2\end{array}$ & $\begin{array}{r}\text { Bushels. } \\
308 \\
237 \\
232 \\
230 \\
283 \\
148 \\
232 \\
364 \\
164 \\
210 \\
64 \\
74 \\
72 \\
36 \\
39 \\
11 \\
27 \\
6 \\
6 \\
7\end{array}$ \\
\hline
\end{tabular}


$\checkmark$ ROCK.

This bed takes it name from the shape of a bare shoal near its southwestern edge. It is inshore of the preceding rock and adjoins Swash Rock to the southeast.

The area and character of growth on the bed are epitomized in the following table:

\section{Oyster Growth on V Rock.}

\begin{tabular}{|c|c|c|c|}
\hline Character of growth. & Area. & $\begin{array}{l}\text { Oysters } \\
\text { per acre. }\end{array}$ & $\begin{array}{l}\text { Estimated } \\
\text { total con- } \\
\text { tent of } \\
\text { oysters. }\end{array}$ \\
\hline 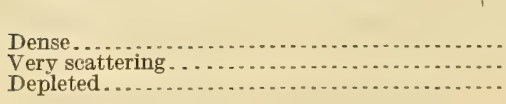 & $\begin{array}{r}\text { Acres. } \\
240 \\
73 \\
73\end{array}$ & $\begin{array}{r}\text { Bushels. } \\
227 \\
84 \\
15\end{array}$ & $\begin{array}{r}\text { Bushels. } \\
54,480 \\
6,132 \\
1,095\end{array}$ \\
\hline Total . . . . . . . . . & 386 & & 61,707 \\
\hline
\end{tabular}

The dense area occupies the middle belt of the bed and carries a growth of between 144 and 344 bushels per acre, the average estimated yield per day to the tonger being about 21 bushels.

The very scattering growth lies along the northwestern edge of the bed and on a comparatively shallow ridge along the swash channel near its mouth. It bears oysters in a quantity to yield about 7 bushels per acre.

The depleted area adjoins similar bottom on Swash Rock and is practically bare of both oysters and shells. The supply of shells on the rest of the bed is ample to secure their reseeding under proper conditions.

The data for the bed are as follows:

Details of Examination of V Rock.

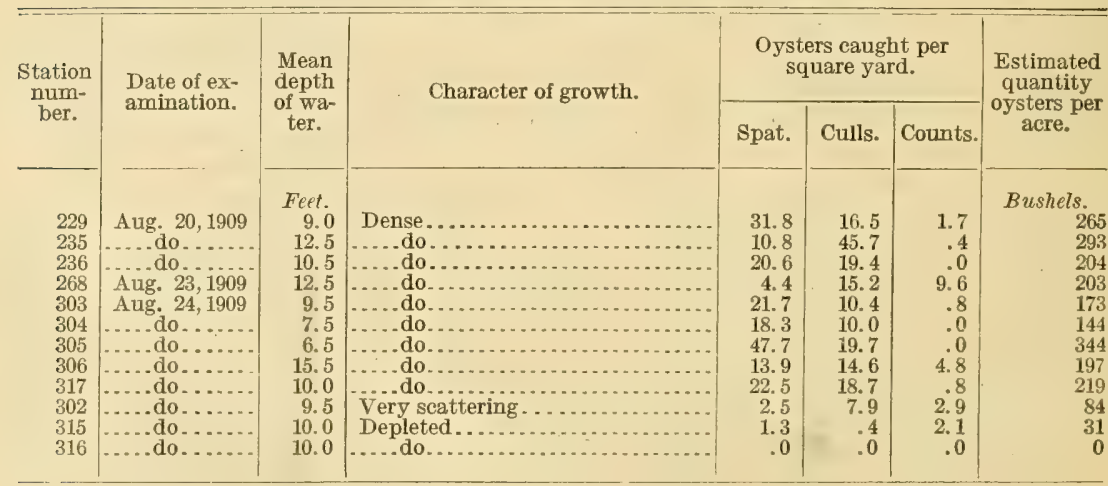


MOORES ROCK.

The bed known to the oystermen by this name lies on a shoal surrounded by deep water about halfway between Point of Shoals Light-House and Mulberry Point. It consists principally of bottom bearing a dense growth, with a scattering fringe along the southern half of its western edge. Its general extent and condition are as follows:

Oyster Growth on Moores Rock.

\begin{tabular}{|c|c|c|c|}
\hline Character of growth. & Area. & $\begin{array}{l}\text { Oysters } \\
\text { per acre. }\end{array}$ & $\begin{array}{l}\text { Estimated } \\
\text { total con- } \\
\text { tent of } \\
\text { oysters. }\end{array}$ \\
\hline $\begin{array}{l}\text { Dense } \\
\text { Scattering................................ }\end{array}$ & $\begin{array}{r}\text { Acres. } \\
37 \\
6\end{array}$ & $\begin{array}{r}\text { Bushels. } \\
265 \\
168\end{array}$ & $\begin{array}{r}\text { Bushels. } \\
9,805 \\
1,008\end{array}$ \\
\hline Total ......... & 43 & $\ldots$. & 10,813 \\
\hline
\end{tabular}

On the dense area the oysters, as developed by the survey, range between 134 and 351 bushels per acre, and it is estimated that the bottom as a whole will produce about 28 bushels of oysters per day of tonging.

The area of scattering growth lies in the deeper water close to the adjoining barren bottom, and its estimated yield to the tonger is about 8 bushels per day. The deposit of shells is good over the entire area of the bed.

Detalus of Examination of Moores Rock.

\begin{tabular}{|c|c|c|c|c|c|c|c|}
\hline \multirow{2}{*}{$\begin{array}{c}\text { Station } \\
\text { num- } \\
\text { ber. }\end{array}$} & \multirow{2}{*}{$\begin{array}{l}\text { Date of ex- } \\
\text { amination. }\end{array}$} & \multirow{2}{*}{$\begin{array}{l}\text { Mean } \\
\text { depth } \\
\text { of wa- } \\
\text { ter. }\end{array}$} & \multirow{2}{*}{ Character of growth. } & \multicolumn{3}{|c|}{$\begin{array}{l}\text { Oysters caught per } \\
\text { square yard. }\end{array}$} & \multirow{2}{*}{$\begin{array}{l}\text { Estimated } \\
\text { quantity } \\
\text { oysters per } \\
\text { acre. }\end{array}$} \\
\hline & & & & Spat. & Culls. & Counts. & \\
\hline $\begin{array}{l}241 \\
265 \\
266 \\
267 \\
242\end{array}$ & $\begin{array}{l}\text { Aug. } 20,1909 \\
\text { Aug. } 23,1909 \\
\ldots \ldots \text { do._...... } \\
\text { Aug. } 20,1909\end{array}$ & $\begin{array}{r}\text { Feet. } \\
9.5 \\
10.5 \\
6.5 \\
5.5 \\
20.5\end{array}$ & \begin{tabular}{l} 
Dense \\
\hdashline do \\
Seattering.
\end{tabular} & $\begin{array}{l}33.4 \\
19.6 \\
28.3 \\
13.3 \\
10.4\end{array}$ & $\begin{array}{l}35.4 \\
19.2 \\
33.4 \\
13.0 \\
12.5\end{array}$ & $\begin{array}{r}0.0 \\
2.5 \\
3.3 \\
.0 \\
.0\end{array}$ & $\begin{array}{r}\text { Bushels. } \\
351 \\
225 \\
350 \\
134 \\
168\end{array}$ \\
\hline
\end{tabular}

HORSEHEAD ROCK.

This bed covers several shoals along the edge of deep water south of Mulberry Point, and for the purpose of this report is considered to include a small patch close to the Baylor line to the eastward. The apex of the bed is detached, but the remainder is continuous, though of varying productiveness. East of this rock and north of Marshy Island Rock the survey found small patches of oysters close to the Baylor line, adjoining or included in various planted beds. This region is shown on the charts. included within red lines but without shading. 
The general distribution of oysters on Horsehead Rock is as follows:

Oyster Growth on Horsehead Rock.

\begin{tabular}{|c|c|c|c|}
\hline Character of growth. & Area. & $\begin{array}{l}\text { Oysters } \\
\text { per acre. }\end{array}$ & $\begin{array}{l}\text { Estimated } \\
\text { total con- } \\
\text { tent of } \\
\text { oysters. }\end{array}$ \\
\hline 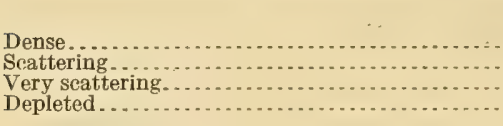 & $\begin{array}{r}\text { Acres. } \\
33 \\
192 \\
199 \\
16 \\
\end{array}$ & $\begin{array}{r}\text { Bushels. } \\
223 \\
104 \\
112 \\
0 \\
\end{array}$ & $\begin{array}{r}\text { Bushels. } \\
7,359 \\
19,968 \\
15,568 \\
0\end{array}$ \\
\hline Total. . & 380 & & 42,895 \\
\hline
\end{tabular}

The areas of dense growth are on the terminal isolated shoal and in two small patches on the main part of the bed. The growth varies between 178 and 283 bushels per acre, and it is estimated that the area as a whole will yield an average of 20 bushels per day to the tonger at the beginning of the season.

On the areas of scattering oysters the density of growth is between 47 and 170 bushels per acre, and it is estimated that they are capable of yielding, at the beginning of the season, an average of about 7 bushels per day per tonger.

On the bottom which is rated as carrying a very scattering growth the average per acre is slightly higher than on the preceding, but as the water is deeper it is less productive in its return per day of labor expended on it.

The depleted bottom lies inshore, close to Mulberry Point, and is practically, in many cases absolutely, bare of oysters and almosit as deficient in shells. On all other areas the deposit of shells is good or fair.

Details of Examination of Horsehead Rock.

\begin{tabular}{|c|c|c|c|c|c|c|c|}
\hline \multirow{2}{*}{$\begin{array}{c}\text { Station } \\
\text { num- } \\
\text { ber. }\end{array}$} & \multirow{2}{*}{$\begin{array}{l}\text { Date of ex- } \\
\text { amination. }\end{array}$} & \multirow{2}{*}{$\begin{array}{c}\text { Mean } \\
\text { depth } \\
\text { of wa- } \\
\text { ter. }\end{array}$} & \multirow{2}{*}{ Character of growth. } & \multicolumn{3}{|c|}{$\begin{array}{l}\text { Oysters eaught per } \\
\text { square yard. }\end{array}$} & \multirow{2}{*}{$\begin{array}{c}\text { Estimated } \\
\text { quantity } \\
\text { oysters per } \\
\text { acre. }\end{array}$} \\
\hline & & & & Spat. & Culls. & Counts. & \\
\hline $\begin{array}{l}256 \\
257 \\
258 \\
263 \\
255 \\
259 \\
261 \\
262 \\
264 \\
273 \\
260 \\
274 \\
280 \\
291 \\
292 \\
293 \\
294\end{array}$ & 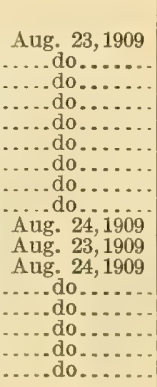 & $\begin{array}{r}\text { Feet. } \\
14.0 \\
7.0 \\
16.0 \\
7.0 \\
18.5 \\
9.0 \\
12.0 \\
7.0 \\
12.0 \\
4.5 \\
16.0 \\
6.0 \\
5.5 \\
5.0 \\
4.5 \\
5.0 \\
7.5\end{array}$ & 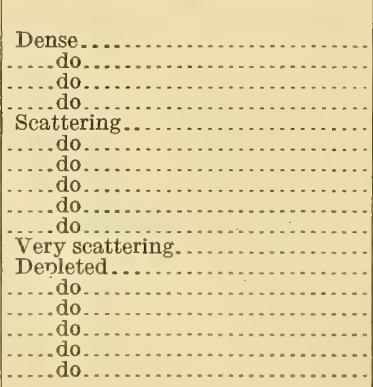 & $\begin{array}{r}19.3 \\
16.5 \\
6.5 \\
9.1 \\
4.1 \\
6.5 \\
5.4 \\
8.1 \\
7.1 \\
.4 \\
.5 \\
.0 \\
.0 \\
.0 \\
.0 \\
.0 \\
.0\end{array}$ & $\begin{array}{r}35.4 \\
22.7 \\
29.6 \\
24.5 \\
6.4 \\
16.9 \\
15.1 \\
5.9 \\
12.5 \\
5.6 \\
16.3 \\
.0 \\
.2 \\
.0 \\
.0 \\
.0 \\
.0\end{array}$ & $\begin{array}{r}0.4 \\
.3 \\
4.1 \\
.6 \\
10.9 \\
1.2 \\
.5 \\
.3 \\
.4 \\
1.1 \\
.5 \\
.3 \\
.0 \\
.0 \\
.0 \\
.0 \\
.0\end{array}$ & $\begin{array}{r}\text { Bushels. } \\
283 \\
203 \\
227 \\
178 \\
170 \\
122 \\
110 \\
74 \\
104 \\
47 \\
112 \\
4 \\
1 \\
0 \\
0 \\
0 \\
0\end{array}$ \\
\hline
\end{tabular}


DEEPWATER SHOALS ROCK.

This is considered as including all oyster bottoms within the Baylor lines above Mulberry Point. Its condition and extent are as follows:

Oyster Growth on Deepwater Shoal Rock.

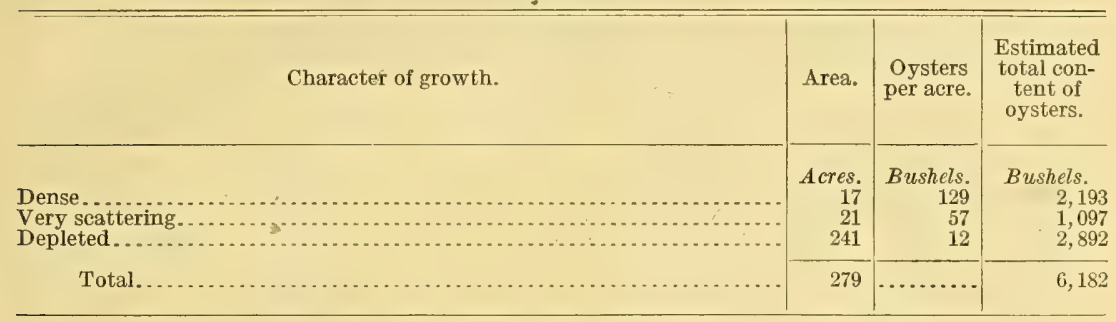

The comparatively small productive area on this bed all lies within a radius of about 1,000 yards of Deepwater Shoals Light-House, most of it being in the immediate vicinity of the light. The dense area is in two small patches on which there is a sufficient growth to yield an average maximum of about 15 bushels per day of actual tonging.

The very scattering areas are three in number, all more or less intimately associated with the preceding. They should yield about 6 bushels per day at the beginning of the season.

The depleted area is practically devoid of oysters. On the areas of dense and very scattering growth there is a good covering of shells, and they are also found in ample numbers on the depleted area within a radius of 1,000 or 1,200 yards of the light, but elsewhere the bed is practically denuded.

The following examinations were made:

Details of Examination of Deeptater Shoals Rock.

\begin{tabular}{|c|c|c|c|c|c|c|c|}
\hline \multirow{2}{*}{$\begin{array}{c}\text { Station } \\
\text { num- } \\
\text { ber. }\end{array}$} & \multirow{2}{*}{$\begin{array}{l}\text { Date of ex- } \\
\text { amination. }\end{array}$} & \multirow{2}{*}{$\begin{array}{l}\text { Mean } \\
\text { depth } \\
\text { of wa- } \\
\text { ter. }\end{array}$} & \multirow{2}{*}{ Character of growth. } & \multicolumn{3}{|c|}{$\begin{array}{l}\text { Oysters caught per } \\
\text { square yard. }\end{array}$} & \multirow{2}{*}{$\begin{array}{c}\text { Estimated } \\
\text { quantity } \\
\text { oysters per } \\
\text { acre. }\end{array}$} \\
\hline & & & & Spat. & Culls. & Counts. & \\
\hline 269 & A 10 g 23,1909 & Feet. & Dense & 4.6 & & 0.3 & Bushels. \\
\hline 270 & ..... do....... & 9.0 & .....do. & 2.1 & 12.9 & 5.8 & 138 \\
\hline 285 & Aug. 24, 1909 & 8. 0 & .... do... & 1.2 & 17.0 & .9 & 158 \\
\hline 272 . & Aug. 23,1909 & 5. 0 & Very scattering. & 1.2 & 7.3 & .0 & 44 \\
\hline 284 & Aug. 24, 1909 & 10.0 & .....do do.......... & .0 & .8 & 4. 2 & 49 \\
\hline 286 & ....do....... & 8. 0 & .....do... & .0 & 7.7 & 3.3 & 74 \\
\hline 288 & ....do do...... & 7. 0 & .... do... & .9 & 4.9 & 3.0 & 62 \\
\hline 271 & Aug. 23, 1909 & 6.0 & Depleted. & .3 & 2.9 & .6 & 23 \\
\hline 282 & Aug. 24, 1909 & 5. 0 & 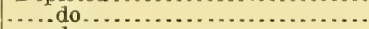 & .0 & .2 & .0 & 1 \\
\hline 283 & .....do....... & 6.0 & .... do & .3 & 1.5 & .0 & 9 \\
\hline 287 & .....do.. & 7.0 & ...do... & .7 & 2.2 & .0 & 15 \\
\hline
\end{tabular}


ROCK WHARF SHOALS ROCK.

This bed lies near the western end of Public Ground No. 1, Isle of Wight County, across the river from the group of seed beds previously described. It forms two patches surrounding shoals and consists principally of productive bottom, as shown in the following table:

Oyster Growth on Rock Wharf Shoals Rock.

\begin{tabular}{|c|c|c|c|}
\hline Character of growth. & Area. & $\begin{array}{c}\text { Oysters } \\
\text { per acre. }\end{array}$ & $\begin{array}{l}\text { Estimated } \\
\text { total con- } \\
\text { tent of } \\
\text { oysters. }\end{array}$ \\
\hline $\begin{array}{l}\text { Dense........ } \\
\text { Depleted.... }\end{array}$ & $\begin{array}{r}\text { Acres. } \\
18 \\
8\end{array}$ & $\begin{array}{r}\text { Bushels. } \\
140 \\
11\end{array}$ & $\begin{array}{r}\text { Bushels. } \\
2,520 \\
88\end{array}$ \\
\hline Total............ & 26 & -.......... & 2,608 \\
\hline
\end{tabular}

The dense area should yield an average of about 22 bushels of - oysters per day, and is fairly covered with clean shells. The depleted bottom is practically bare of both oysters and shells.

Detalls of Examination of Rock Wharf Shoals Rock.

\begin{tabular}{|c|c|c|c|c|c|c|c|}
\hline \multirow{2}{*}{$\begin{array}{c}\text { Station } \\
\text { num- } \\
\text { ber. }\end{array}$} & \multirow{2}{*}{$\begin{array}{l}\text { Date of ex- } \\
\text { amination. }\end{array}$} & \multirow{2}{*}{$\begin{array}{c}\text { Mean } \\
\text { depth } \\
\text { of wa- } \\
\text { ter. }\end{array}$} & \multirow{2}{*}{ Character of growth. } & \multicolumn{3}{|c|}{$\begin{array}{l}\text { Oysters caught per } \\
\text { square yard. }\end{array}$} & \multirow{2}{*}{$\begin{array}{c}\text { Estimated } \\
\text { quantity } \\
\text { oysters per } \\
\text { acre. }\end{array}$} \\
\hline & & & & Spat. & Culls. & Counts. & \\
\hline $\begin{array}{l}421 \\
422 \\
420\end{array}$ & \begin{tabular}{|l|} 
Aug. 28,1909 \\
$\ldots$ do $\ldots \ldots$ \\
do
\end{tabular} & $\begin{array}{r}\text { Feet. } \\
4 \\
6 \\
3\end{array}$ & 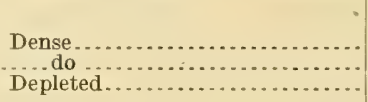 & $\begin{array}{r}7.3 \\
11.3 \\
.0\end{array}$ & $\begin{array}{r}13.6 \\
15.7 \\
.2\end{array}$ & $\begin{array}{r}2.1 \\
1.4 \\
.9\end{array}$ & $\begin{array}{r}\text { Bushels. } \\
129 \\
152 \\
11\end{array}$ \\
\hline
\end{tabular}

BEDS BETWEEN ROCK WHARF SHOALS AND SPINDLE ROCK.

These cover the largest area of productive bottom in the ground, distributed in three patches. Their aggregate area and extent are as follows:

Oyster Growth on Beds Between Rock Wharf Shoals and Spindle Rock.

\begin{tabular}{|c|c|c|c|}
\hline Character of growth. & Area. & $\begin{array}{l}\text { Oysters } \\
\text { per acre. }\end{array}$ & $\begin{array}{l}\text { Total con- } \\
\text { tent of } \\
\text { oysters. }\end{array}$ \\
\hline 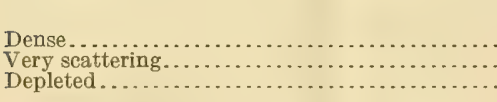 & $\begin{array}{r}\text { Acres. } \\
45 \\
5 \\
37\end{array}$ & $\begin{array}{r}\text { Bushels. } \\
140 \\
46 \\
18\end{array}$ & $\begin{array}{r}\text { Bushels. } \\
6,300 \\
230 \\
666\end{array}$ \\
\hline Total. . & 87 & & 7,196 \\
\hline
\end{tabular}

The dense areas are close to the shoal spots and in various places bear from 101 to 178 bushels per acre, the average density being sufficient to yield about 22 bushels per day to the tonger. 
The bottom of very scattering growth covers but a small spot at the outer end of the middle shoal, and the density of growth is sufficient to yield barely 5 bushels of seed oysters per day.

The depleted bottom is practically denuded. It bears very few shells, and the very scattering bottom is little better in this respect, but the shell deposit on the dense areas is good.

Details of Examination of Beds Between Rock Wharf Shoals and Spindle Rock.

\begin{tabular}{|c|c|c|c|c|c|c|c|}
\hline \multirow{2}{*}{$\begin{array}{c}\text { Station } \\
\text { num- } \\
\text { ber. }\end{array}$} & \multirow{2}{*}{$\begin{array}{l}\text { Date of ex- } \\
\text { amination. }\end{array}$} & \multirow{2}{*}{$\begin{array}{l}\text { Mean } \\
\text { depth } \\
\text { of-wa- } \\
\text { ter. }\end{array}$} & \multirow{2}{*}{ Character of growth. } & \multicolumn{3}{|c|}{$\begin{array}{l}\text { Oysters caught per } \\
\text { square yard. }\end{array}$} & \multirow{2}{*}{$\begin{array}{c}\text { Estimated } \\
\text { quantity } \\
\text { oysters per } \\
\text { acre. }\end{array}$} \\
\hline & & & & Spat. & Culls. & Counts. & \\
\hline $\begin{array}{l}409 \\
417 \\
418 \\
419 \\
425 \\
424 \\
410 \\
416\end{array}$ & 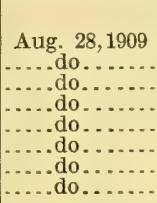 & $\begin{array}{r}\text { Feet. } \\
4.0 \\
6.0 \\
7.0 \\
5.0 \\
3.5 \\
7.5 \\
6.5 \\
7.0\end{array}$ & 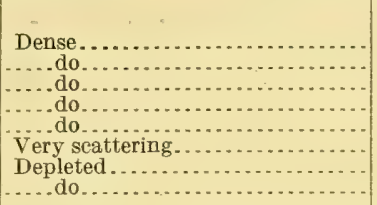 & $\begin{array}{r}8.6 \\
17.0 \\
9.2 \\
9.4 \\
6.2 \\
.5 \\
.3 \\
.0\end{array}$ & $\begin{array}{r}18.2 \\
10.0 \\
9.0 \\
20.0 \\
8.4 \\
3.1 \\
1.3 \\
.3\end{array}$ & $\begin{array}{l}1.0 \\
.8 \\
2.6 \\
2.6 \\
2.5 \\
2.6 \\
1.3 \\
1.3\end{array}$ & $\begin{array}{r}\text { Bushels. } \\
147 \\
146 \\
121 \\
178 \\
101 \\
46 \\
22 \\
15\end{array}$ \\
\hline
\end{tabular}

SPINDLE ROCK.

This bed follows the line of a shoal at right angles to the shores. It consists principally of a dense growth, with insignificant areas of very scattering oysters and depleted bottom at its inner end. Its area and condition at the time of the survey were as follows:

Oyster Growth on Spindle Rock.

\begin{tabular}{|c|c|c|c|}
\hline Character of growth. & Area. & $\begin{array}{c}\text { Oysters } \\
\text { per acre. }\end{array}$ & $\begin{array}{l}\text { Estimated } \\
\text { total con- } \\
\text { tent of } \\
\text { oysters. }\end{array}$ \\
\hline 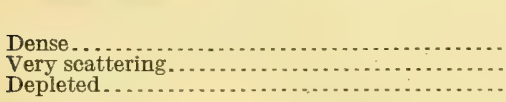 & $\begin{array}{r}\text { Acres. } \\
14 \\
3 \\
2\end{array}$ & \begin{tabular}{|r|} 
Bushels. \\
140 \\
27 \\
12
\end{tabular} & $\begin{array}{r}\text { Bushels. } \\
1,960 \\
81 \\
24\end{array}$ \\
\hline Total. . & 19 & $\ldots$ & 2,065 \\
\hline
\end{tabular}

The dense area bears a growth of between 119 and 179 bushels per acre, and is capable of producing about 21 bushels of oysters per day's tonging; the area of very scattering growth will yield barely 5 bushels and the depleted bottom about 2 bushels. The area of dense growth bears a good supply of shells, that of very scattering growth hardly enough to insure reseeding except under the best conditions, while the depleted bottom is deficient. 
The following examinations were made:

Details of Examination of Spindle Rock.

\begin{tabular}{|c|c|c|c|c|c|c|c|}
\hline \multirow{2}{*}{$\begin{array}{c}\text { Station } \\
\text { num- } \\
\text { ber. }\end{array}$} & \multirow{2}{*}{$\begin{array}{l}\text { Date of ex- } \\
\text { amination. }\end{array}$} & \multirow{2}{*}{$\begin{array}{l}\text { Mean } \\
\text { depth } \\
\text { of wa- } \\
\text { ter. }\end{array}$} & \multirow{2}{*}{ Character of growth. } & \multicolumn{3}{|c|}{$\begin{array}{l}\text { Oysters caught per } \\
\text { square yard. }\end{array}$} & \multirow{2}{*}{$\begin{array}{l}\text { Estimated } \\
\text { quantity } \\
\text { oysters per } \\
\text { acre. }\end{array}$} \\
\hline & & & & Spat. & Culls. & Counts. & \\
\hline $\begin{array}{l}415 \\
426 \\
427 \\
411 \\
412\end{array}$ & 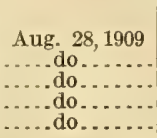 & $\begin{array}{r}\text { Feet. } \\
6.0 \\
4.0 \\
6.0 \\
4.0 \\
4.5\end{array}$ & $\begin{array}{l}\text { Dense } \\
\text { Very scattering } \\
\text { Depleted................... }\end{array}$ & $\begin{array}{r}7.7 \\
8.8 \\
7.4 \\
1.3 \\
.0\end{array}$ & $\begin{array}{r}19.7 \\
14.0 \\
13.6 \\
2.6 \\
.9\end{array}$ & $\begin{array}{r}3.7 \\
.4 \\
1.1 \\
.7 \\
.7\end{array}$ & $\begin{array}{r}\text { Bushels. } \\
179 \\
120 \\
119 \\
27 \\
12\end{array}$ \\
\hline
\end{tabular}

DAYS POINT SHOAL BED.

This follows a shoal but part of which is included in the public ground. The part included embraces a dense growth capable of yielding to the tonger about 27 bushels of oysters per day. The following is the result of the examination made:

Detalls of Examination of Days Point Shoal Rock.

\begin{tabular}{|c|c|c|c|c|c|c|c|}
\hline \multirow{2}{*}{$\begin{array}{l}\text { Sta- } \\
\text { tion } \\
\text { num- } \\
\text { ber. }\end{array}$} & \multirow{2}{*}{$\begin{array}{c}\text { Date of } \\
\text { examination. }\end{array}$} & \multirow{2}{*}{$\begin{array}{c}\text { Mean } \\
\text { depth } \\
\text { of } \\
\text { water. }\end{array}$} & \multirow{2}{*}{ Character of growth. } & \multicolumn{3}{|c|}{$\begin{array}{l}\text { Oysters caught per } \\
\text { square yard. }\end{array}$} & \multirow{2}{*}{$\begin{array}{l}\text { Estimated } \\
\text { quantity } \\
\text { oysters } \\
\text { per acre. }\end{array}$} \\
\hline & & & & Spat. & Culls. & Counts. & \\
\hline 413 & Aug. 28, 1909 & $\begin{array}{l}\text { Feet. } \\
\text { 4.5 }\end{array}$ & Dense. & 7.2 & 22.3 & 1.5 & $\begin{array}{r}\text { Bushels. } \\
166\end{array}$ \\
\hline
\end{tabular}

\section{PUBLIC GROUNDS.}

The public oyster grounds of Virginia are those areas of the bottoms of tide water which are included within the lines of the Baylor survey and additions thereto upon which the public is permitted to take oysters at certain seasons of the year on compliance with certain conditions, and which are withheld from lease for purposes of oyster culture under private and exclusive control.

The public grounds were designed to include all of the natural rocks, though, as has been explained previously, no actual examination was made for the purpose of really determining the facts. The boundaries are necessarily straight lines and do not purport to conform to the outlines of the actual rocks, and largely for this reason they can not fail to include within their confines more or less barren bottom. The relation which the barren bottoms bear to that which actually produces oysters has been in more or less acrimonious dispute between the tongers and dredgers on the one hand and the planters and their partisans on the other, and it was largely to secure authentic and definite information on this point that the present survey was undertaken. 
The public grounds are officially designated by numbers and the name of the county within which they are supposed to lie, and on the accompanying charts their boundaries, accurately platted from the charts of the Baylor survey, are indicated by broken black lines. The boundaries of the natural rocks, as determined by the present survey, are shown in solid red lines, within which the varying density of oyster growth is shown by the relative density of the shading. An inspection of the charts will show that the natural rocks are more or less scattered, between and about them lying barren bottoms, shown as unshaded areas, within the boundaries of the Baylor survey.

At various places it was found that certain private grounds, as indicated by the boundary stakes, encroached more or less on the public grounds, though from the flimsy character of the marks it was difficult in many cases to determine the real facts. This apparent encroachment of private interests on the public domain was observed at various places in Nansemond River, between Fishing Point and Ballards Marsh, about Creek Channel Shoal and Aaron Shoal rocks, in the vicinity of Browns Shoal rocks, at the inshore edges of Kettle Hole and Blunt Point rocks, and at various places between Jail Island and Mulberry Point.

Whatever may have been the conditions under which this encroachment was originally permitted, it was undoubtedly aided by the latter-day uncertainty as to the Baylor boundaries. Apparently but little effort has been made to maintain or replace the shore marks to which the corners of the Baylor survey were referred, and a number of them appear to be now unavailable for reference. The irregularity of the boundaries has also made the maintenance of the lines more difficult, and the same conditions have made it almost impossible for the oyster police to prevent the planters from depredating the public beds beyond their staked boundaries.

These reasons have made it important to both "natural growthers" and planters that an examination should be made into the actual location of the productive areas or those which, though at present more or less unproductive, may be reasonably expected to recuperate under proper natural conditions.

To assist to an understanding of the conditions on the public beds as a whole the following discussion is offered. The several public beds in the region surveyed are considered with regard to the relative areas of dense, scattered, very scattered, and depleted growths, and barren bottom. The first four are measured from the results of the present survey, while the barren bottom is regarded as the difference between the sum of these areas and the areas of the public beds according to Baylor's computations, the data being exhibited in tabular form for each of the several public grounds. For each public ground or for each fraction or combination considered as an entity in the following pages, there are furnished tables and 
summaries of the estimated total contents of market oysters, as distributed by rocks and varying densities of growth. These estimates are interesting, but are misleading if regarded as a measure of productiveness, for a very sparse growth over a large area, as compared with a dense growth over a small one, will give a great aggregate which really represents nothing commercially, as the oysters may be so thinly scattered as to be totally unavailable industrially.

The important point is not how many oysters there may be on a given bed at a given time, but the quantity. of oysters available under existing local economic conditions, the maximum number of bushels that can be removed with profit to the tonger.

It is unnecessary to explain to those familiar with the oyster industry that it is practically impossible to accomplish a complete denudation of the beds in any one season, but there are cases known to the writer, though he has no personal knowledge of the kind in the region under discussion, in which small rocks have been, in effect, taken up bodily, oysters, seed, and shells, and transferred to planted beds.

Under ordinary circumstances, in localities where the cull laws can be and are reasonably enforced, not only the seed or young oysters but a considerable proportion of the market oysters are left on the beds at the end of the season. Eventually, however, the oysters become so scattered that the daily yield to the tonger becomes less than a minimum daily wage, and while the aggregate quantity of marketable oysters left on the beds appears large when expressed in a total of bushels, as in the tables of total contents, it will no longer pay to take them. The minimum average density of growth to which a bed may be reduced before becoming commercially unproductive depends primarily upon the price of oysters. The smaller the market value of a bushel of oysters the greater is the quantity that must be taken per day to furnish a living wage. Another factor that is essentially involved is the amount of culling required, less labor being necessary in handling the oysters when they are single or in small clusters than when they are badly clustered and overgrown with young, from which they must be separated before being placed on the market.

The depth of water is also a very important factor in determining the actual density of growth necessary to render a bed commercially productive. As has been explained in describing the methods pursued in the preparation of this report, the deeper the water the greater must be the quantity of oysters per square yard or acre necessary to afford the tonger a given catch per day. Not only do his tongs of any given length of shaft and head cover a smaller area on the bottom, but the time and labor of making the "grab" - that is, putting the tongs on the bottom, scraping up the oysters, and pulling them up-are materially increased. In other words, in deep water 
not only is the area covered by a "grab" smaller, but, other things being equal, fewer "grabs" can be made in an hour than in a smaller depth.

In the tables shown in this report and on the chart these factors have all been considered in estimating the relative density of the beds. In the estimation of the available contents of the rocks as exhibited in the following tables the same factors have been considered. It is assumed that, at the price which has recently been received for market oysters in the region under considerationnamely, 45 cents per bushel-it would be wholly unprofitable to tong on bottoms which would yield less than 3 bushels of culled oysters per day, exclusive of the time spent in culling, which would ordinarily involve part of the time of a second man or boy. In the same way at the price of seed oysters, namely 30 cents per bushel, it is assumed to be equally unprofitable to tong on bottoms yielding less than 4 bushels, exclusive of shells.

It can not be argued that this limit is too high, but undoubtedly it will be claimed by some that it is entirely too low. The objection would be well founded if it were to apply wholly to areas on which the initial density of growth was such as to afford the minimum yield adopted, but it will not lie against the application of the standard to areas of greater initial productiveness. A dense bed in course of partial denudation by tonging is not uniformly depleted over its whole area. The tongers spread themselves more or less promiscuously over the rocks and take up practically all of the oysters in patches, while other areas are, for the time being, inadvertently left untouched. Later many of these untouched spots are tonged with profit, until the worked areas become so great in proportion to those which have been overlooked that the time spent in searching for the latter makes further work unremunerative. At this stage of temporary abandonment the rock consists of a few small patches of productive bottom, areas which are practically bare of market oysters, and others which have been worked over but still retain some oysters scattered over them by the operations of tonging. It is of course impossible, from the complexity and irregularity of the conditions obtaining on an oyster bed, to fix a limit of more than reasonable accuracy. In preparing the following tables the present available productiveness of each area has been considered with regard to the terms of its initial yield to the tonger and its total estimated contents above that which would give a return of 3 bushels per day's work on the market oyster beds and 4 bushels on the seed beds. The depleted areas and most of the areas covered by what is called very scattered growth are therefore negligible as present factors. A very few areas in the depleted bottoms and a somewhat greater proportion of the bottoms bearing a very scattering growth are of potential value as bearing small oysters and shells which reasonably assure future regeneration. 
These are pointed out in the following discussion of the several public grounds:

\section{PUBLIC GROUNDS NO. 2 NANSEMOND COUNTY AND NO. 6 ISLE OF WIGHT COUNTY.}

These two grounds overlap, as platted on the state charts, and as they can not be accurately differentiated in the conflicting area they may be most conveniently considered together. The former bed begins at the upper limit of oyster growth in the Nansemond River off Cedar Point, and becoming continuous with No. 6 near Newport News Rock, the latter extends along the right side of the James River to beyond Ballards Marsh Rock. Ground No. 2 is said to contain 3,319.6 acres, and Ground No. 6, 4,148.2 acres, a total of 7,467.8; but there is an overlap or duplication of about 305 acres, and deducting this, the actual total area of the two beds may be assumed to be about $7,162.8$ acres. The following is a résumé of the extent of the oyster bottoms of the several rocks and the barren bottom embraced within the limits of these grounds:

Areas of Oyster Growth in Public Grounds No. 2 Nansemond County and No. 6 Isle of Wight County.

\begin{tabular}{|c|c|c|c|c|c|}
\hline \multirow[b]{2}{*}{ Name of oyster rock. } & \multicolumn{5}{|c|}{ Oyster growth. } \\
\hline & Dense. & $\begin{array}{l}\text { Seatter- } \\
\text { ing. }\end{array}$ & $\begin{array}{l}\text { Very } \\
\text { scatter- } \\
\text { ing. }\end{array}$ & Depleted. & Total. \\
\hline 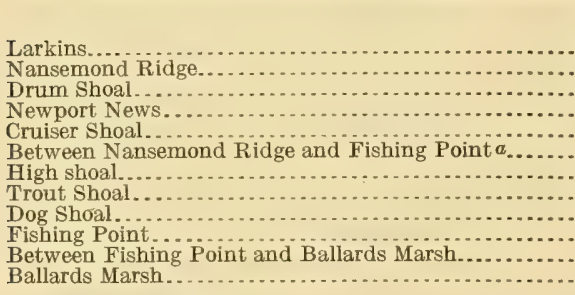 & \begin{tabular}{|r} 
Acres. \\
0 \\
85 \\
0 \\
4 \\
27 \\
50 \\
24 \\
0 \\
16 \\
45 \\
5 \\
0
\end{tabular} & $\begin{array}{r}\text { Acres. } \\
0 \\
446 \\
19 \\
27 \\
19 \\
0 \\
13 \\
25 \\
11 \\
77 \\
0 \\
4\end{array}$ & $\begin{array}{r}\text { Acres. } \\
0 \\
294 \\
14 \\
12 \\
26 \\
5 \\
24 \\
14 \\
35 \\
47 \\
8 \\
33\end{array}$ & $\begin{array}{r}\text { Acres. } \\
39 \\
782 \\
95 \\
129 \\
32 \\
7 \\
95 \\
90 \\
120 \\
90 \\
18 \\
142\end{array}$ & $\begin{array}{r}\text { Acres. } \\
39 \\
1,607 \\
128 \\
172 \\
104 \\
62 \\
156 \\
129 \\
182 \\
259 \\
31 \\
179\end{array}$ \\
\hline 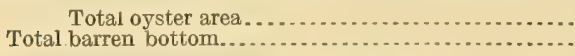 & 256 & 641 & 512 & $\begin{array}{l}1,639 \\
1,63\end{array}$ & $\begin{array}{l}3,048 \\
4,114.8\end{array}$ \\
\hline Total Baylor survey. & & & & & $7,162.8$ \\
\hline
\end{tabular}

$a 8$ acres undetermined.

It will be observed from this table that the barren bottom, as developed by this survey, exceeds the area of the oyster rocks and constitutes about 57 per cent of the area of the two public grounds under discussion. The depleted bottom, which, excepting the places noted in the detailed descriptions of the several beds, is at present unproductive and of a character that gives little or no promise of future regeneration, forms about 23 per cent of the total area included within the Baylor lines. Assuming that the areas of very scattering 
growth, at present practically worthless so far as actual productiveness is concerned, are capable of coming into production at some time in the future, by virtue of the young growth and clean shells that they bear, it will be seen that the actual productive oyster rocks form only about 20 per cent of the area of these two public grounds.

The estimated total marketable contents of the grounds, based upon the distribution of oysters as indicated by the chain, and the actual productiveness of the various areas as determined by actual count and measurement, is exhibited in the following table:

Content of Market Oysters, Public Grounds No. 2 Nansemond-County and No. 6 Isle of Wight County.

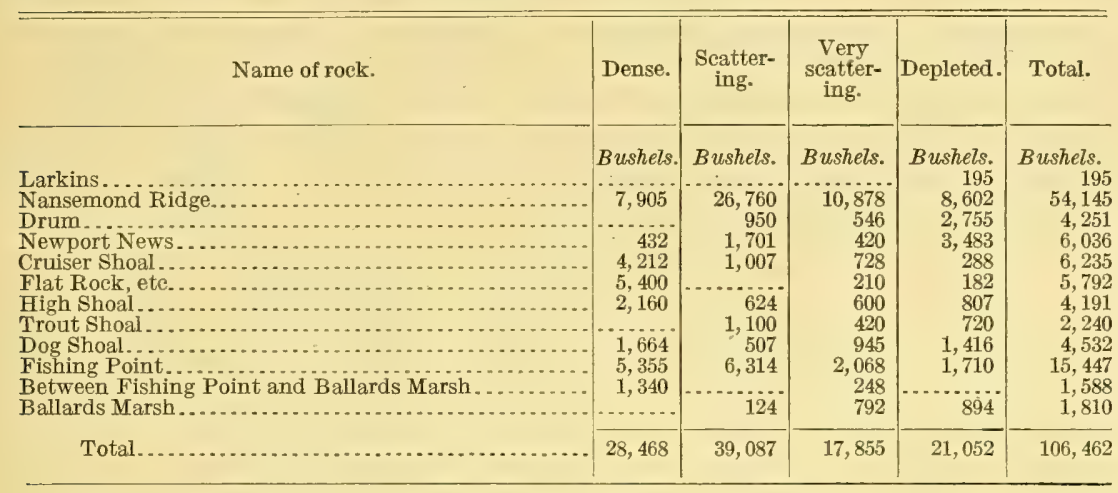

This indicates that if it were possible to "clean up" completely the entire area covered by the oyster rocks, the product would be about 106,000 bushels of marketable oysters. When an analysis is made, it is speedily apparent that the commercially available supply on these beds is only about 40 per cent of the foregoing, as stated in the following table:

Available Content of Market Oysters, Public Grounds No. 2 Nansemond County and No. 6 Isle of Wrght County.

\begin{tabular}{|c|c|c|c|c|}
\hline Name of rock. & Dense. & $\begin{array}{l}\text { Scatter- } \\
\text { ing. }\end{array}$ & $\begin{array}{l}\text { Very } \\
\text { scatter- } \\
\text { ing. }\end{array}$ & Total. \\
\hline Tarkins & Bushels. & Bushels. & Bushels. & Bushels. \\
\hline 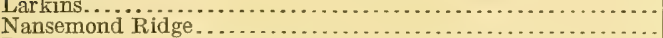 & 5,500 & 13,500 & $\cdots, 000$ & 20,000 \\
\hline Drum & $\ldots . . . . . .$. & 400 & 100 & 500 \\
\hline Newport News & 350 & 850 & ........... & 1,200 \\
\hline Cruiser Shoal ............... & 3,400 & 700 & 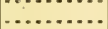 & 4,100 \\
\hline 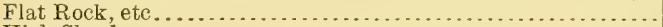 & 3,600 & $\ldots . .$. & ............. & 3,600 \\
\hline 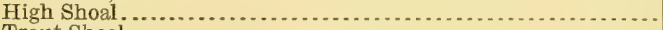 & 1,500 & 350 & 100 & 1,950 \\
\hline 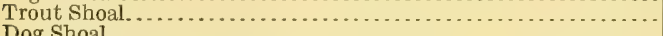 & 1 & 600 & ...... & 600 \\
\hline Dog Shoal & 1,200 & $\begin{array}{r}250 \\
3,600\end{array}$ & $\cdots$ & 1,450 \\
\hline Between Fishing Point and Ballards Marsh.................. & 1,200 & ...... & & 1,200 \\
\hline Ballards Marsh......... . . . . . . . . . . . . . . . . . . . . . . . & & 75 & 100 & 175 \\
\hline Total & 21,150 & 20,325 & 1,600 & 43,075 \\
\hline
\end{tabular}


It will be observed that on the basis assumed in this report the depleted areas are wholly unproductive commercially, and the bottoms covered with very scattered growth are practically so. On the latter the growth in many cases is barely sufficient to yield 3 bushels per day, and in no case does it much exceed that limit. The large aggregate of market oysters on the areas of very scattered and depleted bottoms are. so thinly distributed as to be unavailable commercially, and are therefore valueless except as brood stock to assist in furnishing spat for replenishing the beds. On the dense areas about three-fourths of the total contents and on the scattering growths about one-half may be taken with profit.

The total estimated available product of 43,075 bushels appears very small as compared with the area included within the Baylor lines, averaging but about 6 bushels per acre. It is about half of the average yield of marketable oysters on the public grounds of the State as a whole in 1901 and 1904, according to the statistics of the Bureau of Fisheries, and about equal to the average yield in 1908, as stated by the Bureau of the Census.

The deficiency in productiveness of this section was to be expected in view of public report. The beds, especially in Nansemond River, are generally recognized as being seriously depleted, the allegation of the tongers being that several years ago large quantities of unculled stock were taken from the beds for deposit on private planting ground, and the tonger employed by the survey is authority for the statement that the growth on the Nansemond River beds in the season preceding the investigation was hardly sufficient to warrant tonging.

Combining the exhibits of the tables of areas and of commercially available oysters, we find that it apparently would be profitable to take from the dense growths about 83 bushels per àcre and from the scattering growths an average of about 32 bushels. On the bottoms with a very scattering growth the average content per acre at the beginning of the present oyster season was so small that, even under the very low standard of profit adopted in this report, the beds would be reduced to unproductiveness after an average of only about 3 bushels of oysters per acre had been removed. Of course a very large part of this bottom must be regarded as practically unproductive in the beginning, and it is only here and there that even the least ambitious tonger would venture to work.

Another aspect of the present state of these grounds is the production of young oysters and the presence of shells in such quantities and cleanliness as to afford prospect of a strike under proper conditions. The following table gives the estimated total content of the several rocks and of the grounds as a whole in oysters less than 3 inches long: 
Total Content of Young or Seed Oysters, Public Grounds No. 2 Nansemond County and No. 6 Isle of Wight County.

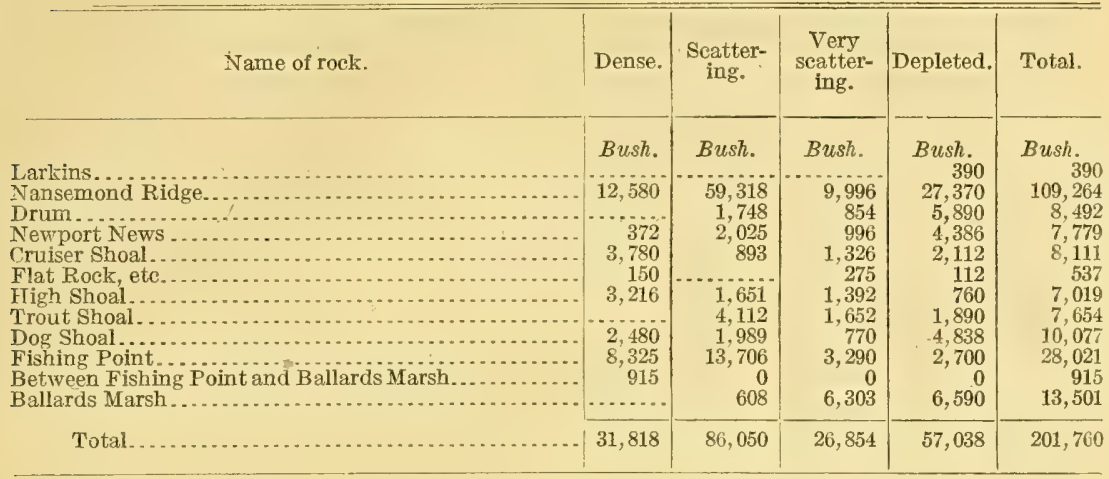

In individuals the small oysters are five or six times as numerous as the market oysters and in measured quantity they are about twice as abundant. On the dense areas they bulk about the same as the market oysters, but as individuals they are two or three times as many. On the scattered area they much exceed the market oysters in numbers and are more than double them in measured quantity. As both of these types of bottom are almost invariably supplied with cultch in the form of clean shells, it can be safely assumed that their future is assured under ordinarily fair conditions and provided the beds are not stripped under infractions of the culling law.

On the area of very scattering growth the quantity of young in nearly every case materially exceeds that of market oysters. Almost the sole exception is Nansemond Ridge Rock, where the young and market oysters are about equal in quantity, the former being decidedly deficient in all places excepting close to the denser areas below a line between Pig and Barrel points.

Excepting Nansemond Ridge Rock the very scattering areas bear an average of about two and one-half times as many bushels of young as of old oysters per acre, and there is nearly everywhere a sufficient abundance of shells to justify the prediction of future regeneration if man will permit. On Nansemond Ridge the future of the very scattering areas, except in a few places, appears unpromising.

The depleted area is, on the whole, deficient in shells and young oysters, and if we except one or two spots near Nansemond Light, the outer end of Ballards Marsh Rock, and several other places quite close to the productive areas, there is but little probability that any of the area will become naturally productive.

$20201-10-5$ 
PUBLIC GROUND NO. 1 WARWICK COUNTY, BELOW DEEP CREEK.

This public ground, while continuous in its lines from near Newport News to above Deepwater Shoals Light, is divided, for purposes of administration, by a line running from Deep Creek to Days Point. Below this line the cull law is in force and tonging is practically confined to taking oysters for the market, while above the line it is legally permissible to take oysters of all sizes for planting purposes. The total area of the portion of the bed here discussed is about 5,515 acres. It embraces six well-defined rocks or groups of rocks, the general condition and area of which are shown in the following table, which also includes a very small contiguous and overlapping area at the inshore edge of Kettle Hole Rock, known as Public Ground No. 2 Warwick County:

Areas of Oyster Growth, Public Ground No, 1 Warwick County, Below Deep Creek.

\begin{tabular}{|c|c|c|c|c|c|}
\hline Name of oyster rock. & Dense. & $\begin{array}{l}\text { Scatter- } \\
\text { ing. }\end{array}$ & $\begin{array}{l}\text { Very scat- } \\
\text { tering. }\end{array}$ & Depleted. & Total. \\
\hline 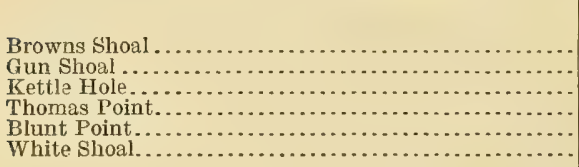 & $\begin{array}{r}\text { Acres. } \\
68 \\
6 \\
258 \\
76 \\
16 \\
44\end{array}$ & $\begin{array}{r}\text { Acres. } \\
44 \\
0 \\
66 \\
118 \\
69 \\
0\end{array}$ & $\begin{array}{r}\text { Acres. } \\
27 \\
16 \\
111 \\
100 \\
225 \\
10\end{array}$ & $\begin{array}{r}\text { Acres. } \\
226 \\
4 \\
11 \\
127 \\
118 \\
52\end{array}$ & $\begin{array}{r}\text { Acres. } \\
365 \\
26 \\
446 \\
421 \\
428 \\
106\end{array}$ \\
\hline 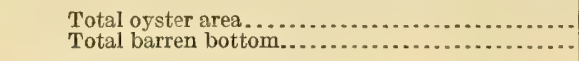 & 468 & 297 & 489 & 538 & $\begin{array}{l}1,792 \\
3,723\end{array}$ \\
\hline Total Baylor survey.. & & & & & 5,515 \\
\hline
\end{tabular}

As shown above, the barren bottom is equal to about 68 per cent of the area included within the Baylor lines, while the depleted area, which is almost uniformly worthless in its present condition, is equal to about 10 per cent. Assuming, as has been done in the discussion of the preceding grounds, that the bottom bearing a very scattering growth, of little or no present value so far as its market-oyster content is concerned, is capable of regeneration under the operation of natural agencies, the total present or prospective productive bottom constitutes about 22 per cent of the entire area. The following table shows the estimated present market-oyster content of the several rocks and their respective subdivisions according to density of growth: 
Content of Market Oxsters, Public Ground No. 1 Warwick County; Below Deep Creek.

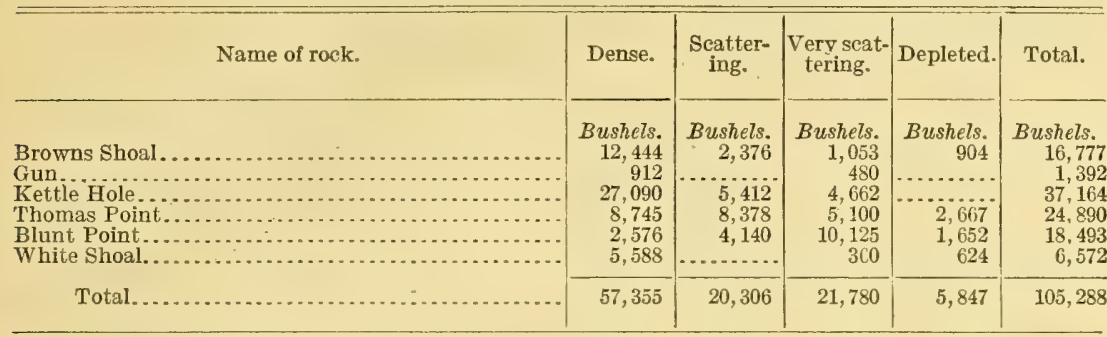

The total content is nearly equal to that of the two grounds first described, but it will be observed that it is differently. distributed, the dense areas bearing about twice the quantity of marketable oysters, the scattering about half as many, the very scattering about one-third more, and the depleted about three-fourths the quantity. With the exception of the depleted bottom, the average growth per acre is in each case somewhat greater than upon the grounds on the opposite side of the James and in the Nansemond River.

As will be understood from what has gone before, this distribution of the total content is to the distinct advantage of the oysterman, as a larger proportion of the oysters may be removed before work on the beds becomes unremunerative. The estimated available content of the beds embraced within this part of the public grounds-that is, the probable maximum yield during the present season-is shown in the following table:

Avallable Content of Market Oysters, Public Ground No. 1 Warwick County, Below Deep Creek.

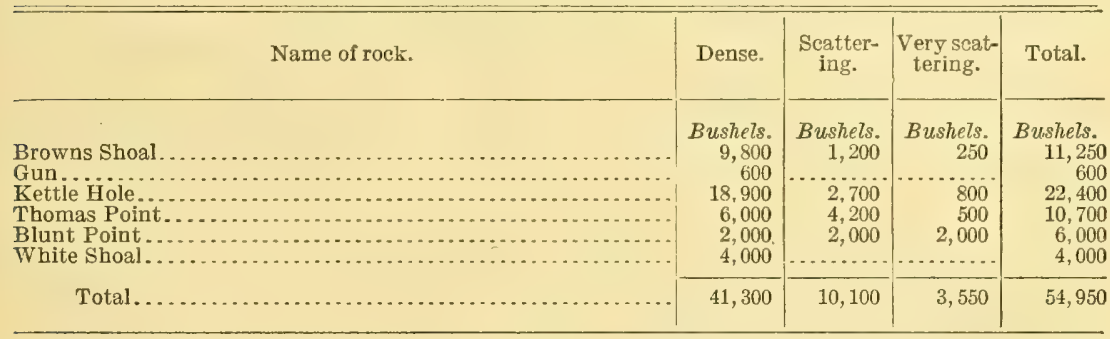

Practically four-fifths of the available oysters are found on the areas charted as bearing a dense growth, and about two-thirds of the remainder are on the areas of scattering growth. The bottoms covered by oysters in very scattering growths are slightly more productive than the average of the grounds previously described, but there are comparatively fow spots on which a tonger could make a minimum livelihood. It is estimated that on the dense areas as a whole nearly three-fourths of the total content, on the scattering areas 
about one-half, and on the very scattering areas not over one-sixth could be removed with profit. The depleted bottoms are worthless for their present product of market oysters.

The yield per acre of bottom included within the Baylor lines is considerably greater than on the grounds previously described, the average being almost 10 bushels, 2 bushels less than the average of the entire public area of Virginia in 1904, and considerably more than the average reported by the Census Bureau in 1908. The average available product of the oyster rocks, excluding all barren bottom but not that which is depleted, is about 30 bushels per acre. The average of the dense area is about 88 bushels, of the scattering area 34 bushels, and of the very scattering growth about 7 bushels per acre. The rocks in this ground are, on the whole, so far as present productiveness is concerned, in better condition than those across the river. The probable future productiveness of the beds, so far as the present existence of young oysters is concerned, is illustrated in the following table:

Total Content of Young or Seed Oysters, Public Ground No. I Warwick County, Below Deep Creek.

\begin{tabular}{|c|c|c|c|c|c|}
\hline Name of rock. & Dense. & $\begin{array}{l}\text { Seatter- } \\
\text { ing. }\end{array}$ & $\begin{array}{c}\text { Verv scat- } \\
\text { tering. }\end{array}$ & Depleted. & Total. \\
\hline 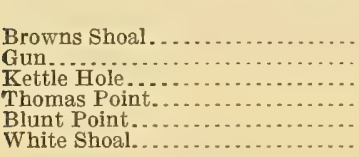 & $\begin{array}{r}\text { Bushels. } \\
8,568 \\
1,188 \\
81,786 \\
12,768 \\
2,736 \\
14,728\end{array}$ & $\begin{array}{r}\text { Bushels. } \\
6,248 \\
13,662 \\
20,060 \\
13,317\end{array}$ & \begin{tabular}{|r|} 
Bushels. \\
2,376 \\
992 \\
19,980 \\
10,300 \\
23,625 \\
1,080
\end{tabular} & \begin{tabular}{r} 
Bushels. \\
1,130 \\
\hdashline$\ldots$ \\
10,160 \\
4,956 \\
2,756
\end{tabular} & $\begin{array}{r}\text { Bushels. } \\
18,322 \\
2,180 \\
115,428 \\
53,288 \\
44,634 \\
18,564\end{array}$ \\
\hline Total... & 121,774 & 53,287 & 58,353 & 19,002 & 252,416 \\
\hline
\end{tabular}

The exhibit here is much more favorable than on the rocks included $\mathrm{n}$ the grounds previously described, the average growth of young oysters on the dense and very scattering areas being over double that on the beds across the river, while that on the scattering area is about 35 per cent greater.

Practically everywhere on the areas of dense and scattererl growth there is a prolific growth of young oysters and an abundance of clean shells, and there is no present prospect of the failure of these areas to continue to produce marketable oysters under ordinary conditions and with a reasonable enforcement of the laws. On the areas of very scattering growth the conditions are mixed, some places being well insured against the future and others being decidedly deficient in bot'1 young growth and clean shells. On Browns Shoal Rocks there is, with the exception of a few places, an abundance of shells; but there are only two or three patches where there is a supply of small oysters ample to replace the present market growth. On Kettle Hole Rock the conditions are grood practically everywhere, but on Thomas Point and 
Blunt Point Rocks there are but a few places where the young growth is prolific, and there are some in which neither young nor shells are found in even the minimum quantity requisite. On White Shoal Rock the condition on the areas of very scattering growth is in general satisfactory.

On the depleted bottoms as a whole the average growth of young oysters is about equal to that on similar bottom across the river, and there appears to be but little prospect of the future improvement of these areas, although there are a few spots on Thomas Point and White Shoal Rocks, in proximity to productive areas, where the growth of young is good.

\section{MINOR PUBLIC GROUNDS.}

In the Nansemond River and on the right side of James River there are several small public grounds, all of which are insignificant both in area and productiveness, and some of which were examined not at all or unsatisfactorily. They are as follows (somewhat more detailed data concerning some of them may be found in the descriptions of the individual rocks):

Nansemond County Ground No. 3. This was intended to include Holland Rock and at present contains in depleted bottom about 22 acres, on which there are a very few oysters and shells and about 33.9 acres of barren bottom.

Isle of Wight County Ground No. 2 contains about 9 acres of bottom of various degrees of productiveness, 24 acres of depleted and 16.8 acres of barren bottom. Its general condition is related in the description of Aaron Shoal Rock, its only natural bed. Isle of Wight County Ground No. 3 adjoins the preceding and has an area of $6 \frac{1}{2}$ acres. It was not examined in the present survey. Isle of Wight County Ground No. 4 lies inshore of the preceding and covers about 3 acres of apparently depleted bottom.

Isle of Wight County Ground No. 5 embraces Creek Channel Shoal Rock, covering about 2 acres of depleted and 5.1 acres of barren bottom. Its present condition is described under the name of the rock.

PUBLIC GROUND NO. 1 WARWICK COUNTY, ABOVE DEEP CREEK.

The lower part of this ground, lying below Deep Creek, is within the area from which market oysters only can be taken and is therefore subject to the operations of the cull law. Its beds have been discussed in the foregoing. Above Deep Creek and Days Point, on both sides of the river, the cull law is suspended so far as young oysters are concerned, and, while shells must be returned to the beds, there is no limit on the minimum size of oysters which may be taken, the whole area being set apart for the production of seed for replanting. 
It is necessary, therefore, in the discussion of the productiveness of this part of the James River oyster grounds, to adopt a different standard of productiveness. The whole oyster product of whatever size is involved in the question of the present value of the beds, whereas in the areas previously discussed the market oysters only could be considered, and the quantity of young was of interest merely as indicating the probability of the beds being maintained or repleted. In the discussion which follows here the maximum potential yield is considered as the production in excess of that. which will give the tonger 4 bushels of oysters per day of tonging, not taking into consideration the time employed in culling out the shells and returning them to the beds.

This part of Ground No. 1 includes all oyster rocks on the left bank of the James River, from the mouth of Warwick River to the upper limit of oyster growth, near Deepwater Shoals Light-House. The following is a summary of the extent of the several rocks and the barren bottoms embraced within the Baylor lines:

Areas of Oyster Growth, Public Ground No. 1 Warwick County, Above Deep Creek.

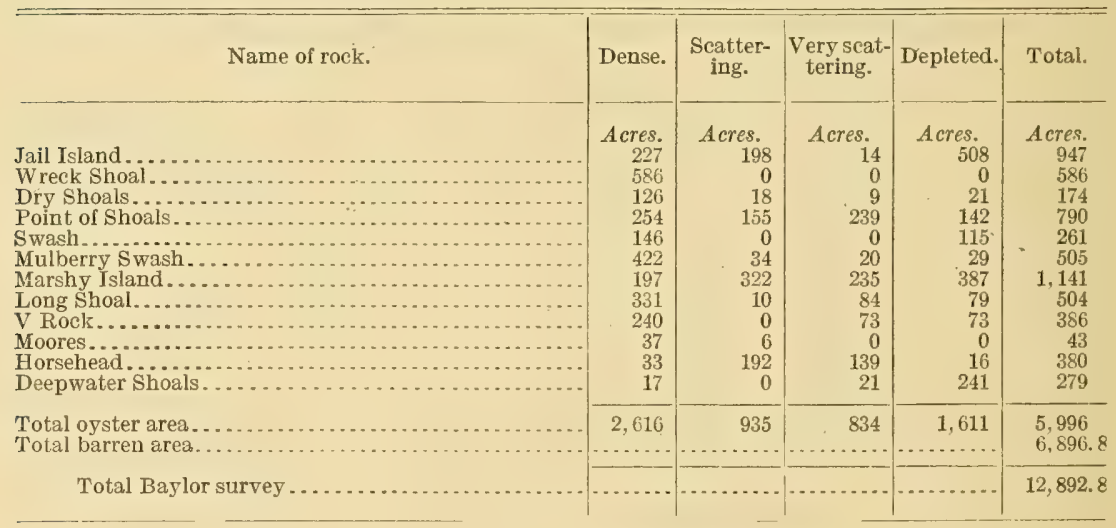

It will be noticed at once that the proportion of barren bottom to that actually included in the rocks as determined by the survey is somewhat smaller than in the grounds previously discussed, constituting about 53 per cent of the total. The depleted bottom, which, with practically no exceptions, is at present and potentially valueless, covers an additional 12 or 13 per cent, so that, assuming all the rest to be at present productive or capable of becoming so in the future. the oyster bottom covers about 35 per cent of the whole.

The following table exhibits the estimated total content of the sereral rocks and their subdivisions at the opening of the oyster season on September 15, 1909: 
Total Content of Oysters, Public Ground No. 1 Warwick County, Above Deep Creek.

\begin{tabular}{|c|c|c|c|c|c|}
\hline Name of rock. & Dense. & $\begin{array}{c}\text { Scatter- } \\
\text { ing. }\end{array}$ & $\begin{array}{c}\text { Very scat- } \\
\text { tering. }\end{array}$ & Depleted. & Total. \\
\hline 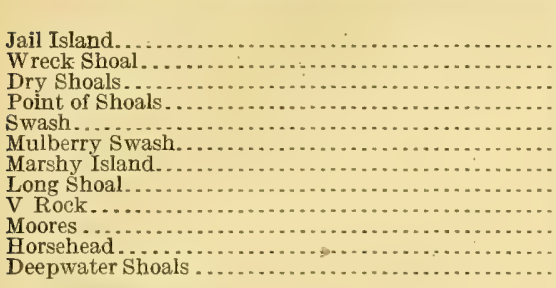 & $\begin{array}{r}\text { Bushels. } \\
32,461 \\
185,176 \\
30,766 \\
50,800 \\
42,778 \\
127,444 \\
45,507 \\
79,771 \\
54,480 \\
9,805 \\
7,359 \\
2,193\end{array}$ & $\begin{array}{r}\text { Bushels. } \\
21,582 \\
2,232 \\
14,415 \\
3,604 \\
41,538 \\
640 \\
1 ., 008 \\
19,968 \\
\ldots \ldots . . .\end{array}$ & $\begin{array}{r}\text { Bushels. } \\
392 \\
765 \\
10,038 \\
2,600 \\
19,975 \\
5,040 \\
6,132 \\
15,568 \\
1,097\end{array}$ & \begin{tabular}{r} 
Bushels. \\
4,064 \\
$\ldots \ldots . .$. \\
420 \\
2,130 \\
1,725 \\
1,247 \\
6,966 \\
1,264 \\
1,095 \\
\hdashline$\ldots . .$. \\
2,892
\end{tabular} & $\begin{array}{r}\text { Bushets. } \\
58,499 \\
185,176 \\
34,183 \\
77,383 \\
44,503 \\
134,895 \\
113,986 \\
86,715 \\
61,707 \\
10,813 \\
42,895 \\
6,182\end{array}$ \\
\hline Total. & 668,540 & 104,987 & 61,607 & 21,803 & 856,937 \\
\hline
\end{tabular}

It will be seen that the great preponderance of oyster production is on the dense areas, which exceed the bottoms of other character not only in their average productiveness but in their total area. The bottoms with a scattering growth, which in extent exceed the next lower grade by about 12 per cent, excel them in their total content by about 70 per cent, and are considerably more important in total production than the combined areas of very scattering oysters and depletion. Summarizing, the dense areas bear 78 per cent of the total content of the rocks, the scattering areas atout 12 per cent, the very scattering about 7 per cent, and the depleted bottom about 3 per cent. Basing the computation on the basis previousiy defined and the data presented in the preceding two tables, we find the estimated maximum available product of the several rocks and their subdivisions to be as follows:

Avallable Content of Oysters, Public Ground No. 1 Warwick County, Above Deep Creek

\begin{tabular}{|c|c|c|c|c|}
\hline Name of rock. & Dense. & $\begin{array}{l}\text { Scatter- } \\
\text { ing. }\end{array}$ & $\begin{array}{c}\text { Very scat- } \\
\text { tering. }\end{array}$ & Total. \\
\hline 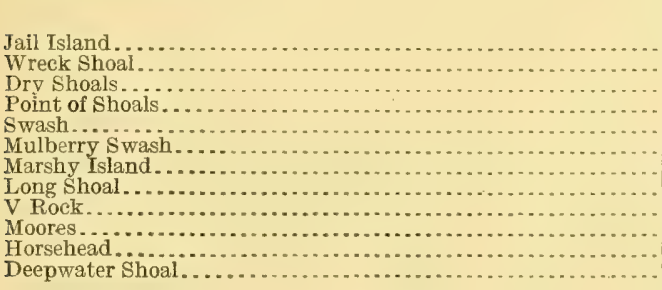 & $\begin{array}{r}\text { Bushels. } \\
25,000 \\
160,000 \\
26,000 \\
42,000 \\
38,000 \\
116,000 \\
35,000 \\
68,000 \\
44,000 \\
7,500 \\
6,000 \\
1,000\end{array}$ & $\begin{array}{r}\text { Bushels. } \\
12,000 \\
1,300 \\
8,500 \\
1,800 \\
25,000 \\
300 \\
11,000\end{array}$ & \begin{tabular}{r} 
Bushels. \\
100 \\
$\cdots$ \\
\hdashline 1,000 \\
1,000 \\
7,500 \\
1,500 \\
2,500 \\
500 \\
7,000 \\
400
\end{tabular} & $\begin{array}{r}\text { Bushels. } \\
37,100 \\
160,000 \\
27,300 \\
51,500 \\
38,000 \\
118,800 \\
67,500 \\
69,800 \\
46,500 \\
8,000 \\
24,000 \\
2,000\end{array}$ \\
\hline Total. & 569,100 & 59,900 & 21,500 & 650,500 \\
\hline
\end{tabular}


The foregoing may be assumed to be the maximum quantity of seed oysters that can be profitably taken from the beds during the present season and the actual yield will probably fall considerably below the total exhibited in the table. Of the total, the areas of dense growth are capable of producing 88 per cent, of scattering growth 9 per cent, and of very scattering growth 3 per cent. The estimated yield per acre of bottom included within the boundary lines of this part of the bed is about 50 bushels. This low average of production is of course induced by the large area of barren and depleted or practically barren bottom included in the Baylor lines. If we compare the average of the whole area with that of the best bottom in the natural rocks under discussion the paucity of the former is equally impressive, the dense areas of the region under discussion having an average total content of about 256 bushels per acre and a promised yield during the present season of 213 bushels, over four times the average of the beds as a whole. The average available product of the areas of scattering growth is about 64 bushels per acre, and of very scattering growth about 13 bushels, both yields being far below what they should produce under proper conditions.

Upon the dense areas as a whole the present production and the promise for the future are both good, and on the area of scattering growth, while the present production is fair, the quantity of shells is such as to promise a better yield in the future, should there come a season of heavy and general strike.

On the bottoms rated as bearing a very scattering growth the conditions as a whole are not such as to yield much profit to the tonger, though in some places he could make a living wage for a short period. In most places on bottom of this character the quantity of clean shells is such as to give indifferent prospect of the future regeneration of the beds.

The depleted bottom, excepting in a few places near Deepwater Shoals Light-House, bears shells in such small quantities as to make exceedingly remote the probability of any material improvement under natural conditions.

PUBLIC GROUND NO. 1 ISLE OF WIGHT COUNTY.

This ground extends as a narrow strip along the right bank of James River from close to the shore line out to the main channel, between Rock Wharf and Days Point Shoal. It lies wholly within the area set apart for seed production, and the statements in regard to the methods employed in computing the productiveness of the several parts of the preceding ground are applicable to this as well.

Compared with the extensive areas occupied by the rocks across the river in Warwick County, the beds included in this ground are 
insignificant. For the purposes of this report it is considered to include four natural rocks, although the largest of these, for which no name was obtained from the oystermen, may be locally recognized by names for its constituents severally. The general condition and extent of the bed are shown in the following table:

Areas of Oyster Growth, Public Ground No. 1 Isle of Wight County.

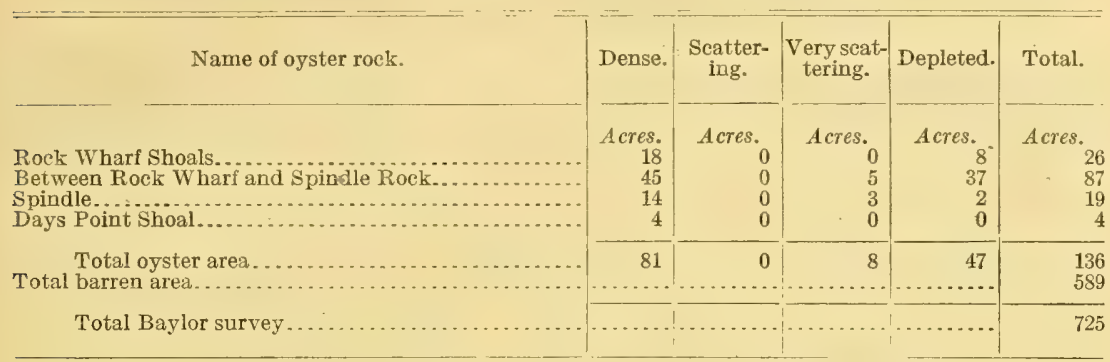

The area of barren bottom as compared with the extent of the ground is relatively large, constituting about 81 per cent, and the depleted bottom, which is at present worthless and holds forth no promise of improvement, adds an additional 7 per cent to the wholly unproductive bottom. The area of dense growth, which is undoubtedly productive, covers about 11 per cent of the whole, while the bottom bearing very scattered oysters, which is at present practically incapable of yielding a living wage to the tonger, covers about 1 per cent.

The following table shows the estimated total content of oysters on the rocks at the end of August, 1909:

Total Content of Oysters, Public Ground No. 1 Isle of Wight County.

\begin{tabular}{|c|c|c|c|c|c|}
\hline Name of rock. & & $\begin{array}{l}\text { Scatter- } \\
\text { ing. }\end{array}$ & $\begin{array}{c}\text { Very scat- } \\
\text { tering. }\end{array}$ & Depleted. & Total. \\
\hline 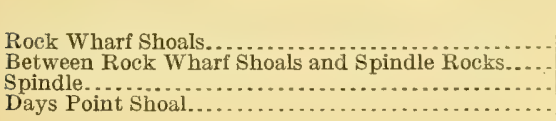 & $\begin{array}{r}\text { Bushels. } \\
2,520 \\
6,300 \\
1,960 \\
664\end{array}$ & 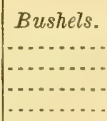 & \begin{tabular}{|r} 
Bushels. \\
230 \\
81
\end{tabular} & $\begin{array}{r}\text { Bushels. } \\
88 \\
666 \\
24 \\
\end{array}$ & $\begin{array}{r}\text { Bushels. } \\
2,608 \\
7,196 \\
2,065 \\
664\end{array}$ \\
\hline Total. & 11,444 & & 311 & 778 & 12,533 \\
\hline
\end{tabular}

The total content of the ground as a whole averages about 17 bushels per acre. Practically all of this is borne by the small fraction of the bottom classed as dense, on which the average production is at the rate of about 141 bushels per acre, considerably less than on the areas of dense growth on the great beds across the channel. 
The estimated available content on these beds - that is, the quantity which may be removed before tonging will cease to pay even a very small assumed minimum livelihood-is as follows:

Available Content of Oysters, Public Ground No. 1 Isle of Wight County.

\begin{tabular}{|c|c|c|c|c|}
\hline Name of rock. & Dense. & $\begin{array}{l}\text { Scatter- } \\
\text { ing: }\end{array}$ & $\begin{array}{l}\text { Very scat- } \\
\text { tering. }\end{array}$ & Total. \\
\hline 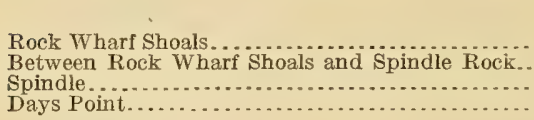 & $\begin{array}{r}\text { Bushels. } \\
2,000 \\
5,000 \\
1,500 \\
500\end{array}$ & $\begin{array}{l}\text { Bushels. } \\
-\ldots \\
\cdots\end{array}$ & $\begin{array}{r}\text { Bushels. } \\
-50 \\
20\end{array}$ & $\begin{array}{r}\text { Bushels. } \\
2,000 \\
5,050 \\
1,520 \\
500\end{array}$ \\
\hline Total... & 9,000 & $\ldots$ & 70 & 9,070 \\
\hline
\end{tabular}

Practically all of the available supply of oysters on this ground is therefore on the bottom classed as dense and the area of very scattering growth is negligible. The available product is of the average density of 111 bushels per acre. On the dense area the shells are sufficient, on the very scattering area they are in fair quantity, while on the depleted ground they are deficient.

\section{SUM MARY.}

The public grounds in the region covered by the survey and of which a detailed discussion is found in the preceding pages cover an area of 26,408.4 acres as computed in the report of the Baylor survey. Of this acreage, 12,790.6 acres lie below the line drawn between Deep Creek and Days Point and $13,617.8$ acres lie above that line. The beds of the former region are available for the production of marketable oysters only, the law requiring that all oysters under 3 inches long be returned to the beds, while the latter region is set apart for the production of seed oysters, and the cull law is not applicable except in so far as it forbids the removal of shells.

Of the entire area the recent survey shows that 3,227 acres may be classed as bearing a dense growth, 2,078 as scattering, 1,848 as very scattering, 3,884 as depleted, and $15,371.4$ as barren. The barren and depleted bottoms together comprise 19,255.4 acres, or about 73 per cent of the total, and all bottom which can be construed as productive aggregates 7,153 acres, or 27 per cent of the entire bottom included within the Baylor lines. Owing to the difference in the provisions of the law applicable to the two regions and the resultant difference in the character of their product, it is necessary to present separate summaries of their present condition.

MARKET OYSTER AREA.

The beds of this region are shown on chart 1 accompanying this report, to which, and to the preceding pages, readers are referred 
for detailed data. The following table summarizes the extent and character of the bottom included within the Baylor lines:

Summarized Statement of Market Oyster Areas on Public Grounds.

\begin{tabular}{|c|c|c|c|c|c|c|}
\hline Name of ground. & Dense. & $\begin{array}{l}\text { Seatter- } \\
\text { ing. }\end{array}$ & $\begin{array}{l}\text { Very seat- } \\
\text { tering. }\end{array}$ & Depleted & Barren. & Total. \\
\hline Nansemond No. 2 & $\begin{array}{r}\text { Acres. } \\
256\end{array}$ & $\begin{array}{r}\text { Acres. } \\
\quad 646\end{array}$ & $\begin{array}{r}\text { Acres. } \\
514\end{array}$ & $\begin{array}{c}\text { Acres. } \\
1,640\end{array}$ & $\begin{array}{l}\text { Acres. } \\
4,106.8\end{array}$ & $\begin{array}{c}\text { Acres. } \\
7,162.8\end{array}$ \\
\hline $\begin{array}{l}\text { 1sle of Wight No. } 6 . \\
\text { Nansemond No. } 3 . .\end{array}$ & 0 & 0 & 0 & 22 & 33.9 & 55.9 \\
\hline $\begin{array}{l}\text { Isle of Wight No. } 2 . . \\
\text { Isle of Wight No. } 3 .\end{array}$ & $2(?)$ & 4 & 3 & 24 & 16.8 & 49.8 \\
\hline Isle of Wight No. $4 . .$. & & & & & & \\
\hline $\begin{array}{l}\text { Isle of Wight No. } 5 \\
\text { Warwick No. } 1 \text { and No. } 2 \text { (below Deep }\end{array}$ & 0 & 0 & 0 & 2 & 5.1 & 7.1 \\
\hline 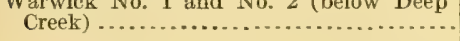 & 468 & 297 & 489 & 538 & $3,723.0$ & $5,515.0$ \\
\hline 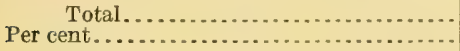 & $\begin{array}{l}726 \\
5.7\end{array}$ & $\begin{array}{l}947 \\
7.4\end{array}$ & $\begin{array}{r}1,006 \\
7.9\end{array}$ & $\begin{array}{r}2,226 \\
17.4\end{array}$ & $\begin{array}{r}7,885.6 \\
61.6\end{array}$ & $\begin{array}{r}12,790.6 \\
100.0\end{array}$ \\
\hline
\end{tabular}

It is estimated that the bottoms embraced by the several grounds, classified in accordance with their relative productiveness, have a total content of market oysters as follows:

Summarized Content of Market Oysters on Public Grounds.

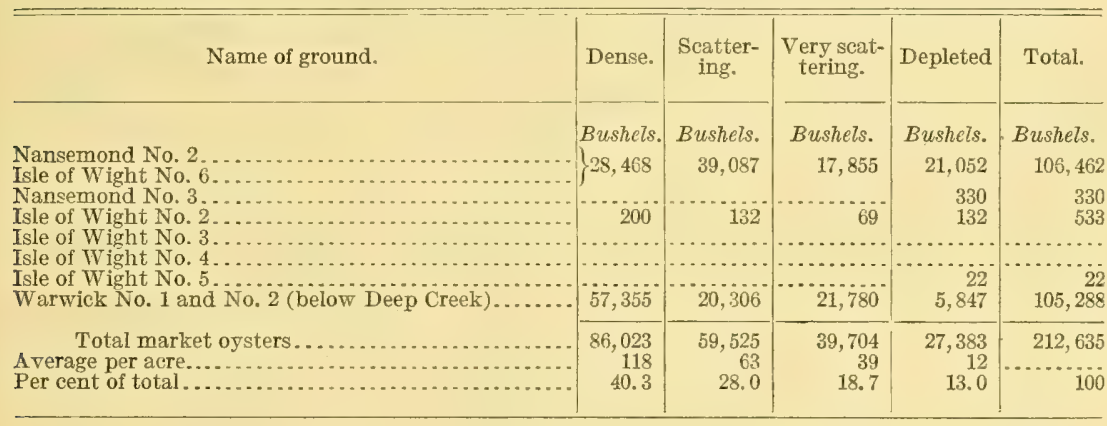

This table is more or less misleading, as the real factor involved is the quantity of oysters which can be profitably removed from the beds. It must be obvious that the total quantity lying on the bottom can not be regarded as commercially available, for when the density of growth is reduced below a more or less definite minimum the value of the average catch will fall below a minimum living wage and work will cease. The minimum average quantity per unit of bottom which will suffice to support commercial operations will depend upon the price of oysters and the depth of water. In this report the price is placed at 45 cents per bushel, and although it will vary somewhat on the different beds and at different times, it is not practicable to make distinctions. The price adopted is based on the testimony of a number of oystermen as to their returns in recent years. The depth of water is a highly variable factor, and as it is of prime importance in 
computing the availability of the oysters lying on the bottom, its variations have been given the fullest possible consideration. For a discussion of the general principles on which the quantity of oysters available with profit have been determined, the reader is referred to preceding pages. For the market oyster beds as a whole the following table gives a summary:

Summary of Avallable Content of Market Oysters on Public Grounds.

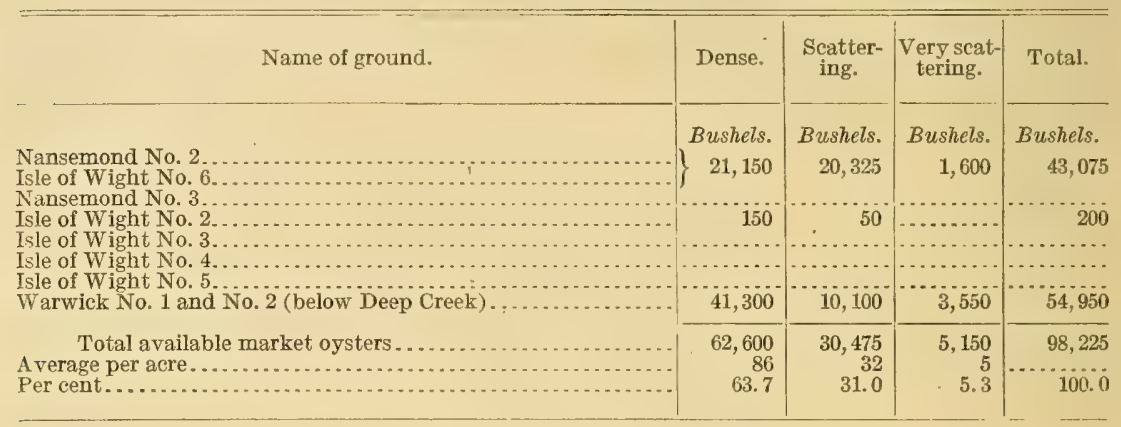

This may be regarded as a maximum estimate of the probable yield of the beds during the season of 1909-10. Owing to the low basis adopted as a minimum wage the yield may not reach the quantity indicated, as it is doubtful whether the beds can be profitably fished as closely as has been assumed. A yield of $\$ 1.35$ per full day of tonging will leave a very small balance after culling and other expenses are deducted, and the beds undoubtedly will be abandoned for the season before this degree of depletion has been reached. 'For this reason the only parts of the natural rock which can be classed as really productive are those designated as dense and scattering, which furnish, according to the foregoing estimates, about 95 per cent of the available product while constituting only about 13 per cent of the total area of the public grounds under consideration.

Taken as a whole, though there are exceptions noted in the preceding accounts of the individual rocks, the areas covered with very scattering growths are of but little present value, their total estimated available product during the present season being valued at less than $\$ 2,500$, or about $\$ 2.50$ per acre. There is, however, another phase to the question which has been touched on in the more detailed accounts of the individual rocks. This is the possibility of future improvement, and is dependent upon the existing quantity of young oysters and the presence of an ample supply of clean shells to serve as places of attachment for future generations of young. The quantity of young oysters less than 3 inches long on the public grounds under discussion at the opening of the present oyster season was as follows: 
Summarized Content of Young Oysters on Public Grounds.

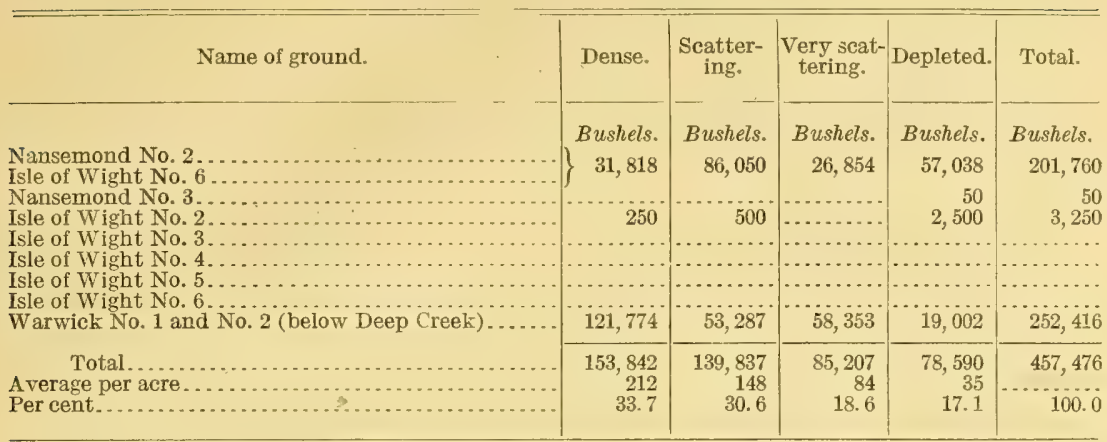

Here again is evidence that the areas of dense and scattering growth should be regarded as not only at present but prospectively productive beds. In quantity, and to a greater extent numerically, the young are considerably in excess of the market oysters, and, as in both classes of bottom under consideration the latter are sufficient to render the bottom undoubtedly at present productive, the abundance of young is sufficient to continue productiveness, under proper regulations as to culling, for at least two years. After the lapse of that period the condition will depend upon the extent of the strike, and other factors concerning which nothing can be predicted.

So far as the areas covered with a very scattering growth are concerned closer scrutiny is required. As these bottoms are on the verge of depletion in respect to market oysters, the proportion of young to large oysters should be greater to insure that the conditions will improve in the future.

The writer is not in possession of definite experimental data applicable specifically to the James River, but from a knowledge of conditions in other parts of the Chesapeake region he feels justified in assuming that oysters as an average will become fit for market in from two to three years from the time of fixation or setting. If experience elsewhere be a guide, some oysters will grow more rapidly and some less rapidly; but two years may be adopted, with very little question, as an irreducible minimum for the average age at which they can be advantageously put on the market. On this assumption and neglecting, for the time being, the question of mortality, it is at once apparent that to maintain the present status there must be two small oysters for each market oyster killed or caught.

There is no way to determine, without long and painstaking observations, the actual average mortality at various ages on the natural rocks of James River. The experience of planters of seed oysters is valueless in this connection, being based on oysters handled and 
otherwise subjected to abnormal conditions. The various locations of the natural-bed oysters and the consequently variable conditions to which they are exposed introduce a factor for which it is difficult to make allowances, and it seems impossible to do more than hazard a guess as to the proportion of young oysters now on the beds which will die before becoming marketable. It is probable that it will be somewhere between 25 and 50 per cent. Considering the size of young oysters found by the survey, the mortality may be less than the former and excepting under unfavorable conditions can hardly be greater than the latter. Assuming that 25 per cent of the young now on the beds will die before reaching a marketable size, there should be on the beds, in order to maintain their present condition, 2.66 young for each marketable oyster removed. If the loss be assumed at 50 per cent there should be 4 young per market oyster.

The following table exhibits the actual average numerical proportion of young oysters to marketable found on the several beds:

Numerical Proportion of Young Growth and Market Oysters in the MarketOyster Area on Bottoms Bearing Verx Scattering Growth.

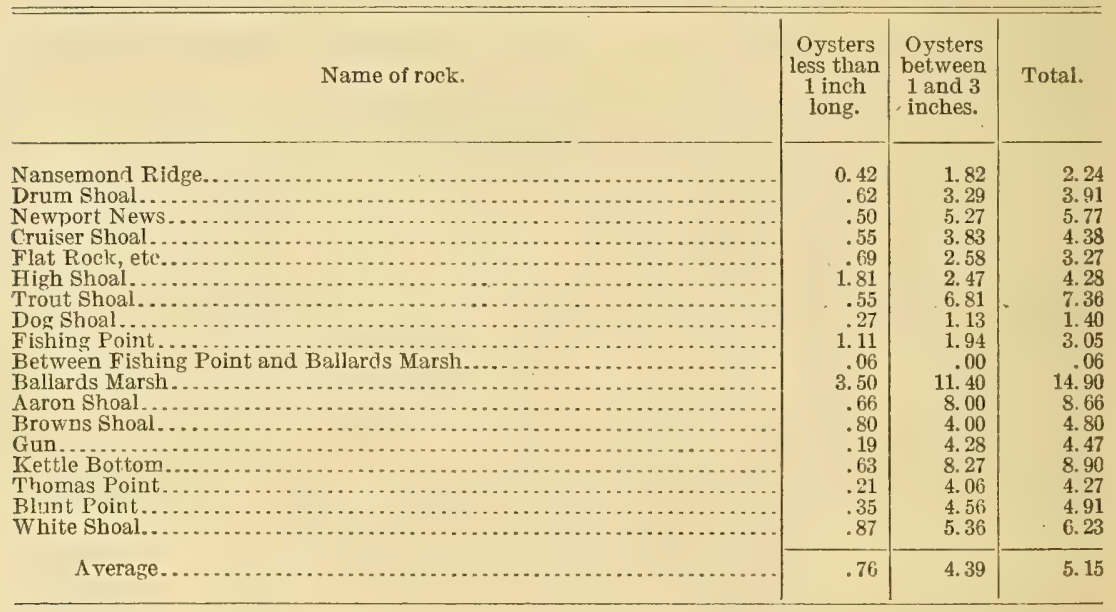

It will be observed that, on the assumption of the smaller death rate, Nansemond Ridge, Dog Shoal, and the small beds near Ballards Marsh are the only rocks which appear to lack sufficient young growth on the very scattering areas to maintain them in their present condition. Assuming the higher rate of mortality, Drum Shoal, the small bed near Flat Rock, and Fishing Point Rocks must be added to the list, though when we consider that many of the market oysters now on the bottom can not be taken with profit, it would appear that even these rocks are capable of improving under a rigid observance of the cull law. The other rocks, under either assumption as to mortality, probably bear a sufficient number of young to 
maintain their present condition or to cause slight improvement in their productiveness, and the real question at issue largely resolves itself into a matter of their present productiveness, which has been already discussed. Most of these bottoms are sufficiently clothed with shells to insure their share of a good strike. The depleted areas, excepting in the places specifically mentioned in the descriptions of the individual rocks, may be regarded as hopeless of recuperation under natural conditions.

The barren bottoms, which preceding tables show to constitute a very large proportion of the areas of the public beds, are in many cases so situated as to be of necessity and for practical considerations impossible of separation from the natural beds without injury to the future of the latter or without due regard to the question of policing and administration. There are, however, certain large areas readily separable from the public grounds, and the latter would suffer practically no diminution in really productive bottom as a result of the severance.

\section{SEED-OYSTER AREA.}

This region lies above the line drawn between Deep Creek and Days Point, and is shown on chart 2 accompanying this report. The following table summarizes the extent and condition of the bottoms of different degrees of productiveness included within this part of the Baylor survey:

Summarized Statement of Oyster Growth on Seed Areas.

\begin{tabular}{|c|c|c|c|c|c|c|}
\hline Name of ground. & Dense. & $\begin{array}{l}\text { Scatter- } \\
\text { ing. }\end{array}$ & $\begin{array}{l}\text { Verv scat- } \\
\text { tering. }\end{array}$ & Depleted. & Barren. & Total. \\
\hline $\begin{array}{l}\text { Warwick No. } 1 \text { (above Deep Creek). } \\
\text { Isle of Wight No. } 1 . . . . . . . . . . . .\end{array}$ & $\begin{array}{r}\text { Acres. } \\
2,420 \\
81\end{array}$ & $\begin{array}{r}\text { Acres. } \\
1,131 \\
0\end{array}$ & $\begin{array}{r}\text { Acres. } \\
834 \\
8\end{array}$ & $\begin{array}{r}\text { Acres. } \\
1,611 \\
47\end{array}$ & $\begin{array}{r}\text { Acres. } \\
6,896.8 \\
589.0\end{array}$ & $\begin{array}{r}\text { Acres. } \\
12,892.8 \\
725.0\end{array}$ \\
\hline $\begin{array}{r}\text { Total.......... } \\
\text { Per cent........... }\end{array}$ & $\begin{array}{r}2,501 \\
18.4\end{array}$ & $\begin{array}{r}1,131 \\
8.3\end{array}$ & $\begin{array}{l}842 \\
6.2\end{array}$ & $\begin{array}{r}1,658 \\
12.2\end{array}$ & $\begin{array}{r}7,485.8 \\
54.9\end{array}$ & $\begin{array}{r}13,617.8 \\
100.0\end{array}$ \\
\hline
\end{tabular}

The following table furnishes an estimate of the total content of seed oysters present on the bottoms of varying productiveness at the beginning of the oyster season on September 15, 1909:

Summarized Content of Oysters on Seed Areas.

\begin{tabular}{|c|c|c|c|c|c|}
\hline Name of ground. & Dense. & $\begin{array}{l}\text { Seatter- } \\
\text { ing. }\end{array}$ & $\begin{array}{l}\text { Very scat- } \\
\text { tering. }\end{array}$ & Depleted. & Total. \\
\hline 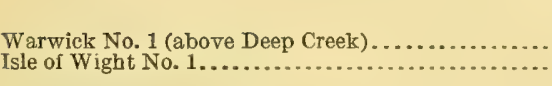 & $\begin{array}{r}\text { Bushels. } \\
668,540 \\
11,444\end{array}$ & $\begin{array}{l}\text { Bushels. } \\
104.987\end{array}$ & $\begin{array}{r}\text { Bushels. } \\
61,607 \\
311\end{array}$ & $\begin{array}{r}\text { Bushels. } \\
21,803 \\
778\end{array}$ & $\begin{array}{r}\text { Bushels. } \\
856,937 \\
12,533\end{array}$ \\
\hline 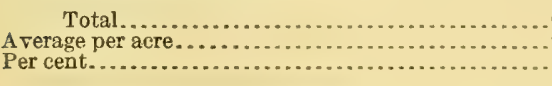 & $\begin{array}{r}679,984 \\
272 \\
78.2\end{array}$ & $\begin{array}{r}104,987 \\
93 \\
12.1\end{array}$ & $\begin{array}{r}61,918 \\
73 \\
7.1\end{array}$ & $\begin{array}{r}22,581 \\
13 \\
2.6\end{array}$ & $\begin{array}{r}869,470 \\
100.0\end{array}$ \\
\hline
\end{tabular}


A considerable proportion of these oysters could not be profitably removed from the beds, being either too sparsely distributed in the first place or constituting a necessary remnant which would become too scattered after tonging had been carried on for a period on bottoms of greater initial productiveness. To show the estimated maximum possible yield of the beds during the present season the following table has been prepared, covering the entire area of seed beds in the James River:

Summary of Avallable Content of Oysters on Seed Areas.

\begin{tabular}{|c|c|c|c|c|c|}
\hline Name of ground. & , & Dense. & $\begin{array}{l}\text { Seatter- } \\
\text { ing. }\end{array}$ & $\begin{array}{c}\text { Very scat- } \\
\text { tering. }\end{array}$ & Total. \\
\hline $\begin{array}{l}\text { Warwick No. } 1 \text { (above Deep Creek) } \\
\text { Isle of Wight No. 1................. }\end{array}$ & & $\begin{array}{r}\text { Bushels. } \\
569,100 \\
9,000\end{array}$ & $\begin{array}{r}\text { Bushels. } \\
59,900 \\
.\end{array}$ & $\begin{array}{r}\text { Bushels. } \\
21,500 \\
70\end{array}$ & $\begin{array}{r}\text { Bushels. } \\
650,500 \\
9,070\end{array}$ \\
\hline $\begin{array}{l}\text { Total.......... } \\
\text { Average per acre.... } \\
\text { Per cent............. }\end{array}$ & & $\begin{array}{r}578,100 \\
232 \\
87.7\end{array}$ & $\begin{array}{r}59,900 \\
53 \\
9.1\end{array}$ & $\begin{array}{r}21,570 \\
25 \\
3.2\end{array}$ & $\begin{array}{r}659,570 \\
100.0\end{array}$ \\
\hline
\end{tabular}

In preparing the data on which this table is based it has been assumed that the seed will bring 30 cents per bushel and that no bottom can be considered productive when its yield is reduced below 4 bushels per day of actual tonging, excluding the time occupied in culling. As in the preceding pages of this report, the probable yield is based on the density of the oyster growth and the depth of water on the several parts of each bed.

Although the data employed differs somewhat from that used in the discussion of the bottoms below Deep Creek, owing to the lower price brought by seed as compared with market oysters, the financial return to the tonger from the bottoms designated as respectively dense, scattering, and very scattering is essentially the same. The minimum yield assumed to place a given area above the grade of depleted bottom is valued at $\$ 1.20$ per day at the prices recently prevailing, and this can not be regarded as other than an extreme minimum, because, when the number of idle days is taken into consideration, a tonger could not afford to work for such low wages. The limit is justifiable only in consideration of the fact that before the dense and scattering areas are reduced to a level so low they will have yielded to the tonger an average daily wage much in excess of this.

If the price of oysters falls below 30 cents per bushel, it will not be profitable to work the beds so closely as was contemplated in the preparation of the above table. At the prices reported as current on the James River in November, 1909, namely, 20 cents per bushrl for seed, the estimated catch on the area of very scattering growth may be eliminated, that on the scattering bottom reduced by at least 50 per cent and on the dense areas by about 15 per cent, lowering the 
total estimated catch to about 500,000 bushels as a maximum which could be taken with profit.

As was the case with the market-oyster beds, the areas described as bearing dense and scattering growths may be dismissed from further discussion as being at present productive. The areas bearing a very scattering growth are debatable, with seed oysters selling at 30 cents per bushel, but would be undoubtedly entirely neglected by the tongers were the price to fall to 20 cents. Their estimated yield at the former price is about $\$ 7.50$ per acre, and from the entire area of 842 acres the total product during the present season would not exceed in value $\$ 6,500$, even if the tongers were willing to work for an average of about $\$ 1$ per day, exclusive of the time lost through bad weather.

The future of these areas of very scattering growth is difficult to forecast. When, as in the area under discussion, there is not and from the nature of the case should not be any application of the cull law, there is no young growth which can be pointed to as coming forward to replace the larger oysters removed. Young and old alike are taken and the only oysters left are the residuum which it is unprofitable to take. In other words, the annual increment is taken or may be taken in the months immediately following its deposit. The health and perpetuity of the beds depend upon the quantity of clean shells exposed on the bottom ready for the strike which each season may produce. Over the very scattering bottoms of this part of James River there is a fair quantity of shells and under the proper conditions these areas may become more productive.

The depleted bottoms, as a whole, have neither present nor prospective value under natural conditions, though the bottom is generally of such character that if it were feasible to rent it for purposes of oyster culture it could be made highly productive. Much of it is so situated, however, that it is debatable whether, for reasons of administration, it would be advisable to alienate it from the public grounds. An inspection of the charts will show that, excepting along the shores, these bottoms are generally in the midst of productive areas. Concerning the great area of barren bottoms the same statement holds true in part, a considerable proportion of it lying: in the channels and deeper holes between the beds or in other situations which would make it difficult to delimit it from the public grounds in a manner to facilitate the policing of the public rocks and prevent abuses which experience shows would undoubtedly be attempted.

There are, however, certain areas in considerable blocks which could be set apart for purposes of oyster culture without materially reducing the area of the natural rocks included in the public grounds. These places can be determined by an inspection of the chart. $20201-10-6$ 


\section{CONCLUSION.}

The foregoing gives, in detail and summary, the facts as to the condition of the oyster beds of James and Nansemond rivers immediately prior to the opening of the present oyster season, the period at which the beds are at their maximum apparent productiveness. Within a few weeks, under the intensive fishery which they sustain, the quantity of oysters on the beds will be vastly reduced and long before the close of the season they will become so impaired that work on them will be practically abandoned for the time being. In other words, it is for a part of the season only that these beds will offer a livelihood to the tongers, who for the rest of the year must seek a living either in the employ of the oyster grower or in some other occupation not connected with oyster fishing.

In the determination of the nature of tidal bottoms, with respect to their being regarded as oyster rock or barren bottom, the prime consideration is whether they will afford, either at present or prospectively, a sufficient quantity of oysters to provide a livelihood to those who work on them. It is manifest that a few oysters which could never be taken with profit should not entitle the bottom on which they lie to be regarded as an oyster bed within the meaning of the laws. To so regard them would be contrary to common sense, economic principles, and judicial decisions.

The author has avoided a definition of what constitutes a livelihood, believing that to be a matter which is more properly for determination by the state authorities should its definition become necessary for purposes of legislation or administration. In the preparation of the foregoing report, however, it has been necessary to adopt some standard for the classification of the various densities of oyster growth in the several beds, and for purposes of convenience the limit between the bottoms regarded as depleted and those of the lowest class of productiveness has been placed at a minimum believed to be reasonably irreducible. The subdivisions of productiveness differ by such small quantities that should it appear that the lowest is too low the next higher can be regarded as the minimum without impairing the value of the data adduced in the report, though, as is elsewhere indicated, this would dictate a reduction in the estimated total available product of oysters for the season.

Under the terms of the resolution of the State Board of Fisheries, which was made the basis of the request for the survey preferred to the Bureau of Fisheries by the Governor of Virginia, the author is not warranted in offering recommendations as to the use which might be made of the facts developed in the preceding pages. It may not be inappropriate, however, to point out the several avenues of procedure which it is possible to follow in respect to the oyster 
bottoms of the region discussed. These resolve themselves into three: (1) The maintenance of the integrity of the public grounds as now constituted; (2) their abolition in toto; and (3) a middle course which will preserve to the public the productive bottoms practically in their entirety while throwing open to oyster planting a large part of the barren and unproductive bottom now included within the public grounds. The principal arguments for and against these propositions may be epitomized as follows:

1. The first course - that the beds be retained in the present statushardly needs discussion. It has been tried and its results are known, largely as the effect of the acrimonious disputes to which it has given rise. The matters of fact which have been at issue in these interminable discussions, as to whether or not the public grounds embraced any considerable area of barren bottom, have been dealt with in the preceding pages and speak for themselves. It should be pointed out, however, that while the barren area is shown to constitute a considerable proportion of the whole bottom, much of it is so related to the productive bottom that it could not be eliminated under any scheme permitting of practical administration.

2. The second alternative - the total abolition of the public grounds and its corollary, the opening of the whole area for leasing-is drastic. On broad economic grounds the proposition is as logical and legitimate as the sale of public timber land or the breaking up of the great public ranges of the West into holdings in severalty, and, as the oyster is sessile, it has nothing in common with an alienation of the common fishery for nomadic species. The law has already recognized that under conditions an oyster in situ may be property, while a wandering fish can not become such until caught. The breaking up of the public grounds into leaseholds under private control would increase their productiveness precisely as the breaking up of the common ranges of the West has resulted in economic efficiency and greater productiveness. This course would, furthermore, yield a return to the State, where there is now a net outlay for policing the public grounds, though this aspect of the matter is one which should always be held subservient to the major considerationthe welfare and prosperity of the citizen.

On the other side of the question it is necessary to consider the effect of so drastic an innovation upon the welfare of a large body of persons-whose livelihood in part is at present dependent upon the situation to which the policy of the State has given the aspect of presumed permanency. Immediately upon the alienation of the public beds the men engaged on them for part of the season are, for the time being, forced from the category of independent workers into that of employees, unless they themselves elect to take up 
bottoms in severalty. The value of this objection is mainly senti- . mental, but is not less real on that account.

3. The third course mentioned, the retention of the actually productive bottom for the use of the public and the opening of all barren bottom practicable for leasehold from the State, is essentially a compromise between the other two and presents fewer difficulties than either. The valid objections to it are mainly concerned with administration. By retaining the present natural beds intact the tongers would be left in possession of everything of value to which they now have access, while the opening of the barren bottoms for lease would make productive considerable acres now valueless to all. The tongers would still have the option of independent work on the natural rocks; they would have increased opportunities of employment by the planters; and some of them could themselves lease bottoms for their own use. In every way it would appear to be economically advantageous to the industry and the State.

In considering the subject, however, it should be borne in mind that, while this report shows a preponderance of barren bottom within the public grounds, much of it, owing to its location, is practically incapable of separation from the natural rocks. An inspection of the chart will show that many of the barren bottoms are between or in the midst of naturally productive bottoms. To exclude them would make necessary an undue multiplication of the public grounds, with an attendant difficulty in policing.

Effectually to prevent depredations on the natural rocks under the guise of work on adjoining planted grounds, which is a difficulty with which the oyster police will have to contend, the public areas should be as few and as compact as possible, and the boundary lines should be straight and easily defined. For this reason the public grounds to be established must, for very practical considerations, necessarily include a considerable proportion of barren bottom. Any readjustment of the lines of the Baylor survey should be based on reasonable compromise and adopted only after careful consideration by the State. It is believed that the foregoing descriptions and the accompanying charts will furnish a reliable basis for a revision, should the State deem it wise to undertake it. 


\section{DESCRIPTION OF CHARTS.}

The public grounds are platted from the published sheets of the Baylor survey, and their boundaries are shown in broken black lines.

The depths, which are expressed in feet as referred to mean low water and the symbols designating the consistency of the bottom, are the characteristics selected from a large number of observations. The oyster beds are included within solid red lines, and the density of the oyster growth is indicated by the relative intensity of the shading, and is based on the quantity of culled oysters which can be taken by a tonger working nine hours per day, not including the time occupied in culling.

Chart 1 covers the area from which market oysters only may be removed, and the bases of the classifications of oyster growth are as follows: Dense, yielding over 8 bushels of market oysters per day's tonging; scattering, between 5 and 8 bushels; very scattering, between 3 and 5 bushels; depleted, under 3 bushels.

Chart 2 embraces the beds of the upper part of James River, on which the cull law is inoperative so far as it pertains to the size of the oysters, and which are therefore devoted to the production of seed oysters for replanting. The classification is as follows: Dense, yielding over 12 bushels of seed oysters per day's tonging; scattering, between 8 and 12 bushels; very scattering, between 4 and 8 bushels; depleted, under 4 bushels.

The unshaded areas within the boundaries of the public beds as charted represent barren bottom. 



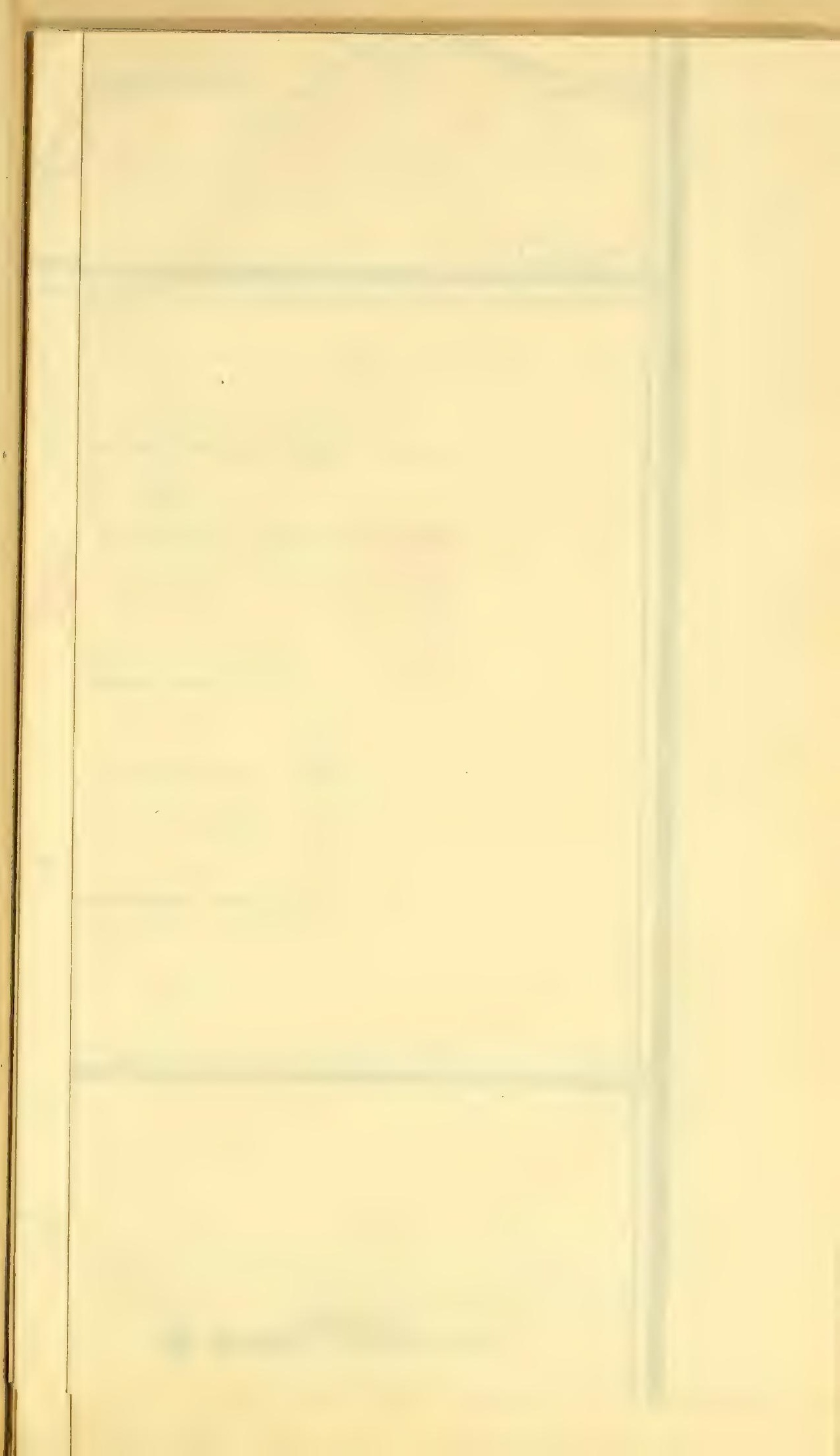











